\title{
A box model study on photochemical interactions between VOCs and reactive halogen species in the marine boundary layer
}

\author{
K. Toyota ${ }^{1, *}$, Y. Kanaya ${ }^{1}$, M. Takahashi ${ }^{1,2}$, and H. Akimoto ${ }^{1}$ \\ ${ }^{1}$ Frontier Research Center for Global Change, Japan Agency for Marine-Earth Science and Technology, 3713-25 \\ Showa-machi, Kanazawa-ku, Yokohama 236-0001, Japan \\ ${ }^{2}$ Center for Climate System Research, The University of Tokyo, Tokyo 153-8904, Japan \\ *now at: Dept. of Earth and Space Science and Engineering, York Univ., 4700 Keele Street, Toronto, Ontario M3J 1P3 \\ Canada
}

Received: 1 August 2003 - Published in Atmos. Chem. Phys. Discuss.: 1 September 2003

Revised: 24 September 2004 - Accepted: 26 September 2004 - Published: 30 September 2004

\begin{abstract}
A new chemical scheme is developed for the multiphase photochemical box model SEAMAC (sizeSEgregated Aerosol model for Marine Air Chemistry) to investigate photochemical interactions between volatile organic compounds (VOCs) and reactive halogen species in the marine boundary layer (MBL). Based primarily on critically evaluated kinetic and photochemical rate parameters as well as a protocol for chemical mechanism development, the new scheme has achieved a near-explicit description of oxidative degradation of up to $\mathrm{C}_{3}$-hydrocarbons $\left(\mathrm{CH}_{4}, \mathrm{C}_{2} \mathrm{H}_{6}, \mathrm{C}_{3} \mathrm{H}_{8}\right.$, $\mathrm{C}_{2} \mathrm{H}_{4}, \mathrm{C}_{3} \mathrm{H}_{6}$, and $\mathrm{C}_{2} \mathrm{H}_{2}$ ) initiated by reactions with $\mathrm{OH}$ radicals, $\mathrm{Cl}$ - and $\mathrm{Br}$-atoms, and $\mathrm{O}_{3}$. Rate constants and product yields for reactions involving halogen species are taken from the literature where available, but the majority of them need to be estimated. In particular, addition reactions of halogen atoms with alkenes will result in forming halogenated organic intermediates, whose photochemical loss rates are carefully evaluated in the present work. Model calculations with the new chemical scheme reveal that the oceanic emissions of acetaldehyde $\left(\mathrm{CH}_{3} \mathrm{CHO}\right)$ and alkenes (especially $\mathrm{C}_{3} \mathrm{H}_{6}$ ) are important factors for regulating reactive halogen chemistry in the MBL by promoting the conversion of $\mathrm{Br}$ atoms into $\mathrm{HBr}$ or more stable brominated intermediates in the organic form. The latter include brominated hydroperoxides, bromoacetaldehyde, and bromoacetone, which sequester bromine from a reactive inorganic pool. The total mixing ratio of brominated organic species thus produced is likely to reach $10-20 \%$ or more of that of inorganic gaseous bromine species over wide regions over the ocean. The reaction between $\mathrm{Br}$ atoms and $\mathrm{C}_{2} \mathrm{H}_{2}$ is shown to be unimportant for determining the degree of bromine activation in the remote MBL. These results imply that reactive halogen chem-
\end{abstract}

Correspondence to: $\mathrm{K}$. Toyota

(ktoyota@yorku.ca) istry can mediate a link between the oceanic emissions of VOCs and the behaviors of compounds that are sensitive to halogen chemistry such as dimethyl sulfide, $\mathrm{NO}_{\mathrm{x}}$, and $\mathrm{O}_{3}$ in the MBL.

\section{Introduction}

Reactive halogen chemistry involving sea-salt aerosols is potentially important for determining the behaviors of $\mathrm{O}_{3}$, $\mathrm{NO}_{\mathrm{x}}, \mathrm{SO}_{2}$, dimethyl sulfide (DMS), and mercury in the marine boundary layer (MBL). Several exploratory modeling studies have indicated that reactive bromine and chlorine species can build up via autocatalytic halogen release from sea-salt aerosols to strongly influence the fate of the abovementioned species via reactions occurring in the gas phase as well as in aerosols and cloud droplets (Sander and Crutzen, 1996; Vogt et al., 1996; Sander et al., 1999; Toyota et al., 2001; von Glasow et al., 2002a,b; Hedgecock et al., 2003). There also exists circumstantial evidence that reactive halogen chemistry exerts a strong influence on DMS and $\mathrm{O}_{3}$ loss rates in the air over the ocean, as envisaged from large discrepancies between their mixing ratios modeled without halogen chemistry and those observed (e.g. Chin et al., 1998; Dickerson et al., 1999; Nagao et al., 1999; James et al., 2000; Chand et al., 2003). The autocatalytic halogen release is triggered by taking up either $\mathrm{OH}, \mathrm{NO}_{3}, \mathrm{~N}_{2} \mathrm{O}_{5}$, or $\mathrm{O}_{3}$ from the gas phase to oxidize $\mathrm{Br}^{-}$in sea salt (Finlayson-Pitts et al., 1990; Sander and Crutzen, 1996; Hirokawa et al., 1998; Knipping et al., 2000). Caro's acid ( $\mathrm{HSO}_{5}^{-}$), formed via aqueous-phase radical reactions of $S(I V)$, and inorganic iodine species such as HOI, derived from organic iodines of biogenic origin, are also suggested to be effective in oxidizing sea-salt $\mathrm{Br}^{-}$ (Mozurkewich, 1995; Vogt et al., 1996, 1999). Even though 
small initially, the amount of reactive bromine thus produced will increase significantly under sunlight as mediated by a series of reactions in the gas phase and in the acidified seasalt aerosols (Sander and Crutzen, 1996; Vogt et al., 1996; Sander et al., 1999):

$$
\begin{aligned}
& \mathrm{Br}^{-}+\mathrm{HOBr}+\mathrm{H}^{+} \rightarrow \mathrm{Br}_{2}+\mathrm{H}_{2} \mathrm{O} \\
& \mathrm{Cl}^{-}+\mathrm{HOBr}+\mathrm{H}^{+} \rightarrow \mathrm{BrCl}+\mathrm{H}_{2} \mathrm{O} \\
& \mathrm{BrONO}_{2}+\mathrm{Br}^{-} \rightarrow \mathrm{Br}_{2}+\mathrm{NO}_{3}^{-} \\
& \mathrm{BrONO}_{2}+\mathrm{Cl}^{-} \rightarrow \mathrm{BrCl}+\mathrm{NO}_{3}^{-} \\
& \mathrm{BrCl}+\mathrm{Br}^{-} \rightleftharpoons \mathrm{Br}_{2} \mathrm{Cl}^{-} \rightleftharpoons \mathrm{Br}_{2}+\mathrm{Cl}^{-} \\
& \mathrm{Br}+h v \rightarrow \mathrm{Br}+\mathrm{Br} \\
& \mathrm{BrCl}+h v \rightarrow \mathrm{Br}+\mathrm{Cl} \\
& \mathrm{Br}+\mathrm{O}_{3} \rightarrow \mathrm{BrO}+\mathrm{O}_{2} \\
& \mathrm{BrO}+\mathrm{HO}_{2} \rightarrow \mathrm{HOBr}+\mathrm{O}_{2} \\
& \mathrm{BrO}+\mathrm{NO}_{2} \stackrel{\mathrm{M}}{\rightarrow} \mathrm{BrONO}{ }_{2}
\end{aligned}
$$

where reactive chlorine is also released from sea-salt aerosols in this reaction sequence. The observed behaviors of gaseous and particulate inorganic bromine compounds in the midand low-latitude MBL indicate, although not definitively, that the autocatalytic cycle plays a major role in releasing reactive bromine from sea salt. In particular, $\mathrm{BrO}$ mixing ratios measured over the ocean by differential optical absorption spectroscopy (DOAS) instruments were always close to or below the detection limits of a few $\mathrm{pmol} / \mathrm{mol}$ (e.g. James et al., 2000; Leser et al., 2003), which are still within the range of model predictions and, besides, capable of doubling the oxidation rates of $\mathrm{NO}_{\mathrm{x}}$ and DMS as well as augmenting the photochemical loss rate of $\mathrm{O}_{3}$ by at least $5-10 \%$ in the midlatitude MBL (Vogt et al., 1996; Ingham et al., 1999; Sander et al., 1999; Toyota et al., 2001; Boucher et al., 2003). Readers may be referred to Sander et al. (2003) and references therein for a comprehensive review of currently available observational data for inorganic bromine.

Since the autocatalytic halogen release from sea-salt aerosols is a consequence of interplay between the gas- and aqueous-phase reactions, the concentrations of gas-phase compounds that are reactive toward halogen species are among the key factors for the buildup of reactive halogens. For instance, model-predicted bromine activation is notably enhanced by varying $\mathrm{O}_{3}$ mixing ratios from $\sim 10 \mathrm{nmol} / \mathrm{mol}$ to $\sim 20 \mathrm{nmol} / \mathrm{mol}$, since Reaction (8) is an important step to give $\mathrm{HOBr}$ and $\mathrm{BrONO}_{2}$, key compounds for oxidizing halide ions in the aqueous phase (von Glasow et al., 2002a; Wagner et al., 2002). Reactions between $\mathrm{Br}$ atoms and volatile organic compounds (VOCs) will exert an opposite influence on the autocatalytic halogen release by circumventing Reaction (8). To date several studies concerning halogen chemistry in the springtime Arctic boundary layer have addressed the significance of such reactions. For instance, $\mathrm{HCHO}$ and $\mathrm{CH}_{3} \mathrm{CHO}$ are important for determining the magnitude of "bromine explosion" and its impact on $\mathrm{O}_{3}$ loss in the springtime Arctic boundary layer, since these aldehydes are fairly abundant there (typically $[\mathrm{HCHO}] \sim 200 \mathrm{pmol} / \mathrm{mol}$ and $\left[\mathrm{CH}_{3} \mathrm{CHO}\right] \sim 100 \mathrm{pmol} / \mathrm{mol}$ ) and highly reactive toward $\mathrm{Br}$ atoms to give $\mathrm{HBr}$ (Shepson et al., 1996; Sumner and Shepson, 1999). Addition reactions of $\mathrm{Br}$ atoms to $\mathrm{C}_{2} \mathrm{H}_{4}$ and $\mathrm{C}_{2} \mathrm{H}_{2}$ are also suggested to be effective in impeding the bromine explosion, since they result in forming relatively stable brominated intermediates in the organic form; however, the magnitude of their impacts depends strongly on a factor that is not fully characterized, i.e. how stable the reaction products are against subsequent reactions to regenerate inorganic bromine (McConnell et al., 1992; Sander et al., 1997).

Actually, a variety of evidence suggests that oxygenated organic compounds and non-methane hydrocarbons are emitted from the ocean to the overlying atmosphere (e.g. Ratte et al., 1993; Zhou and Mopper, 1997; Lewis et al., 1999, 2001; Singh et al., 2001). In the remote MBL the origins of short-lived VOCs such as $\mathrm{CH}_{3} \mathrm{CHO}$ and low-molecularweight alkenes are often dominated by their oceanic emissions, whereas the impacts of long-range transport from the continents are marginal (Koppmann et al., 1992; Donahue and Prinn, 1993; Plass-Dülmer et al., 1993; Heikes et al., 1996; Saito et al., 2000; Singh et al., 2001). Previous studies have addressed the impacts of oceanic VOCs emissions within the context of $\mathrm{HO}_{\mathrm{x}}-\mathrm{NO}_{\mathrm{x}}$ chemistry and/or organic acids formation (e.g. Arlander et al., 1990; Donahue and Prinn, 1990; Baboukas et al., 2000; Singh et al., 2001).

Here we investigate the potential impacts of short-lived VOCs of oceanic origin on reactive halogen chemistry in the MBL by using the multiphase photochemical box model SEAMAC (size-SEgregated Aerosol model for Marine Air Chemistry) (Toyota et al., 2001). The model takes account of a number of reactions for halogen species $\left(\mathrm{Cl}_{\mathrm{x}}, \mathrm{Br}_{\mathrm{x}}\right)$ as well as $\mathrm{O}_{\mathrm{x}}, \mathrm{HO}_{\mathrm{x}}, \mathrm{NO}_{\mathrm{x}}, \mathrm{SO}_{\mathrm{x}}, \mathrm{CO}$ and hydrocarbon oxidation products in the gas phase and in the deliquesced sea-salt aerosols. For the purpose of this study, the gas-phase reaction scheme is thoroughly updated from that in our previous work to achieve a near-explicit representation of photochemical degradation of up to $\mathrm{C}_{3}$-hydrocarbons (i.e. $\mathrm{CH}_{4}, \mathrm{C}_{2} \mathrm{H}_{6}$, $\mathrm{C}_{3} \mathrm{H}_{8}, \mathrm{C}_{2} \mathrm{H}_{4}, \mathrm{C}_{3} \mathrm{H}_{6}$, and $\mathrm{C}_{2} \mathrm{H}_{2}$ ) initiated by reactions with $\mathrm{OH}$ radicals, $\mathrm{Cl}-$ and $\mathrm{Br}$-atoms, and $\mathrm{O}_{3}$. In the following sections we will start with reviewing the state of knowledge about the origins of $\mathrm{C}_{2} \mathrm{H}_{4}, \mathrm{C}_{3} \mathrm{H}_{6}$, and $\mathrm{CH}_{3} \mathrm{CHO}$ in the MBL (Sect. 2) and will then describe the new chemical mechanism introduced to SEAMAC (Sect. 3). Then the basic framework of SEAMAC will be briefly described and the details of numerical experiments conducted will be explained (Sect. 4). Finally, results of model runs will be presented and discussed within the context of impacts on halogen activation (Sect. 5).

\section{Ethene, propene, and acetaldehyde in the MBL}

Seawater concentrations of low-molecular-weight nonmethane hydrocarbons and some carbonyl compounds have 
been found to be supersaturated relative to their concentrations in the overlying air (Lamontagne et al., 1974; Bonsang et al., 1988; Plass et al., 1992; Donahue and Prinn, 1993; Zhou and Mopper, 1997). These compounds are produced primarily via photochemical degradation of dissolved organic carbon of biogenic origin, whereas their direct formation via biological processes is of secondary importance (Ratte et al., 1993, 1998; Zhou and Mopper, 1997). Among the compounds supersaturated in seawater, the origins of relatively long-lived species including $\mathrm{C}_{2} \mathrm{H}_{6}, \mathrm{C}_{3} \mathrm{H}_{8}$, and $\mathrm{C}_{2} \mathrm{H}_{2}$ appear to be dominated by long-range transport from the continents even in the remote MBL (Koppmann et al., 1992; Plass-Dülmer et al., 1993). On the other hand, low-molecular-weight alkenes including $\mathrm{C}_{2} \mathrm{H}_{4}$ and $\mathrm{C}_{3} \mathrm{H}_{6}$ are almost exclusively derived from their oceanic emissions in the remote MBL (Koppmann et al., 1992; Plass-Dülmer et al., 1993; Heikes et al., 1996). Similarly, Singh et al. (2001) found that the atmospheric mixing ratios of $\mathrm{CH}_{3} \mathrm{CHO}$ simulated by a global-scale tropospheric chemical-transport model of Harvard University were lower by about $80-90 \%$ than observed over the remote tropical Pacific Ocean, suggesting the presence of missing sources including the oceanic emission.

Table 1 lists the observed mixing ratios of $\mathrm{C}_{2} \mathrm{H}_{4}, \mathrm{C}_{3} \mathrm{H}_{6}$, and $\mathrm{CH}_{3} \mathrm{CHO}$ in the MBL with clean air masses as reported in the recent literature. In the present work, model runs are conducted to cover the ranges of these observed mixing ratios by varying net sea-to-air fluxes of these compounds.

Regarding $\mathrm{CH}_{3} \mathrm{CHO}$, only the work of Zhou and Mopper (1997) has quantitatively assessed its sea-to-air flux by measuring the concentrations in the sea surface microlayer and the underlying bulk seawater of the south Sargasso Sea about $100 \mathrm{~km}$ east of the Bahamas. They found that $\mathrm{CH}_{3} \mathrm{CHO}$ is significantly enriched in the surface microlayer compared to the bulk seawater and that the microlayer enrichment becomes greater during the daytime. Applying these measurements to a diffusive microlayer model, the net sea-toair flux of $\mathrm{CH}_{3} \mathrm{CHO}$ was estimated to be approximately $1.2 \times 10^{10}$ molecule $\mathrm{cm}^{-2} \mathrm{~s}^{-1}$. We find that this value is more than enough to give observed $\mathrm{CH}_{3} \mathrm{CHO}$ mixing ratios presented in Table 1 under the mid-latitude MBL conditions. Thus the oceanic emission rates somewhat smaller than estimated by Zhou and Mopper (1997) are used in our model runs (see Sect. 4).

It is interesting to note that a significant enrichment of $\mathrm{HCHO}$ in the sea surface microlayer also takes place as a result of its photochemical production during the daytime. Zhou and Mopper (1997) found the molar concentration of $\mathrm{HCHO}$ in the sea surface microlayer to be even greater than that of $\mathrm{CH}_{3} \mathrm{CHO}$. However, since the hydration constant of HCHO is three orders of magnitude greater than that of $\mathrm{CH}_{3} \mathrm{CHO}$ (whereas their intrinsic Henry's law constants are on the same order, see Zhou and Mopper, 1997, and references therein), HCHO formed in the surface microlayer will diffuse downward to the bulk seawater rather than be emitted

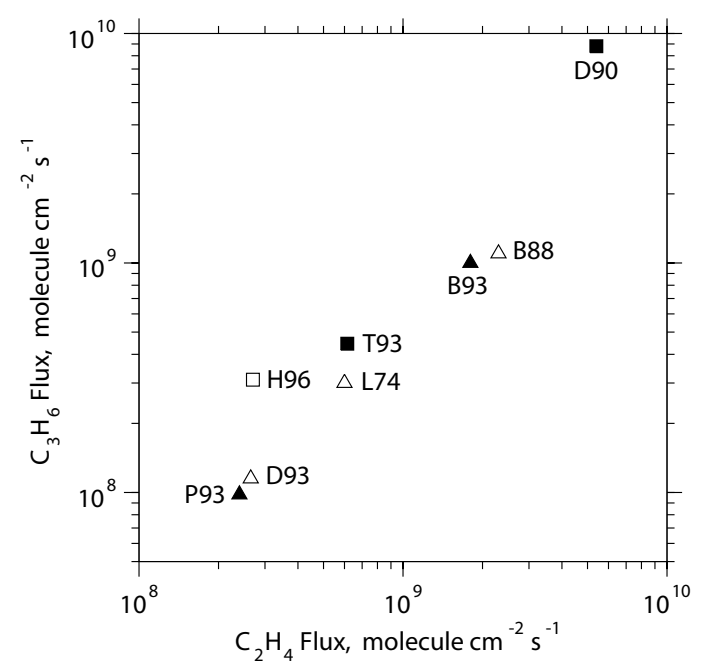

Fig. 1. Estimated sea-to-air fluxes of $\mathrm{C}_{2} \mathrm{H}_{4}$ and $\mathrm{C}_{3} \mathrm{H}_{6}$ reported in the literature: P93, Plass-Dülmer et al. (1993); D93, Donahue and Prinn (1993); H96, Heikes et al. (1996), T93, Thompson et al. (1993); B93, Bonsang (1993); D90, Donahue and Prinn (1990); L74 and B88 were calculated by Donahue and Prinn (1990) from the data of Lamontagne et al. (1974) and Bonsang et al. (1988), respectively. Values marked by triangles were estimated based on measured seawater concentrations with a diffusive microlayer approach and those marked by squares based on measured air concentrations with budget analyses using photochemical models. Values with filled marks (P93, T93, B93, and D90) are used in the model runs of the present work.

to the overlying atmosphere. In other words, the sea surface represents a sink for atmospheric $\mathrm{HCHO}$.

Regarding $\mathrm{C}_{2} \mathrm{H}_{4}$ and $\mathrm{C}_{3} \mathrm{H}_{6}$, a fairly large number of studies have been performed in attempts to estimate their fluxes from the ocean (see Fig. 1). Methods applied in such estimates can be categorized into two types. The first type of method is a diffusive microlayer approach based on observed seawater concentrations (e.g. Plass-Dülmer et al., 1993), which would be less influenced by long-range transport of anthropogenic and/or terrestrial sources than atmospheric concentrations. However, this approach as applied to date might have underestimated the rates of alkene emissions from the ocean, since seawater samples have been generally taken from the bulk subsurface water rather than from the surface microlayer (Lewis et al., 2001). The second type of method is a budget analysis based on observed atmospheric concentrations with the aid of photochemical models (e.g. Heikes et al., 1996). Flux estimates made by Donahue and Prinn (1990) based on this method are significantly greater than other estimates, since the atmospheric data they used are biased toward higher concentrations $\left(\left[\mathrm{C}_{2} \mathrm{H}_{4}\right]\right.$ $\sim 150 \mathrm{pmol} / \mathrm{mol},\left[\mathrm{C}_{3} \mathrm{H}_{6}\right] \sim 100 \mathrm{pmol} / \mathrm{mol}$ ) than those typical of the remote MBL. As suggested by Donahue and Prinn (1993), atmospheric samplings under relatively strong influence of long-range transport from the continents and/or 
Table 1. Mixing ratios of ethene $\left(\mathrm{C}_{2} \mathrm{H}_{4}\right)$, propene $\left(\mathrm{C}_{3} \mathrm{H}_{6}\right)$, and acetaldehyde $\left(\mathrm{CH}_{3} \mathrm{CHO}\right)$ in the marine boundary layer with clean air masses reported in the recent literature.

\begin{tabular}{|c|c|c|c|c|}
\hline Species & Mixing Ratio $^{a}$ & Sampling Location & Sampling Dates & Refs. \\
\hline \multirow[t]{10}{*}{$\mathrm{C}_{2} \mathrm{H}_{4}$} & $58 \pm 26$ & mid-Atlantic, $0^{\circ}$ to $45^{\circ} \mathrm{N}$ & March/April 1987 & 1 \\
\hline & $45 \pm 35$ & mid-Atlantic, $0^{\circ}$ to $45^{\circ} \mathrm{N}$ & September/October 1988 & 1 \\
\hline & $25 \pm 18$ & mid-Atlantic, $0^{\circ}$ to $30^{\circ} \mathrm{S}$ & March/April 1987 & 1 \\
\hline & $22 \pm 9$ & mid-Atlantic, $0^{\circ}$ to $30^{\circ} \mathrm{S}$ & September/October 1988 & 1 \\
\hline & $\sim 50^{b}$ & central Pacific, $15^{\circ} \mathrm{S}$ to $20^{\circ} \mathrm{N}$ and $140^{\circ}$ to $170^{\circ} \mathrm{W}$ & February/March 1990 & 2 \\
\hline & $19-30$ & northern Pacific, $0^{\circ}$ to $40^{\circ} \mathrm{N}$ and $115^{\circ}$ to $180^{\circ} \mathrm{E}$, north of ITCZ & September/October 1991 & 3 \\
\hline & $11-24$ & northern Pacific, $0^{\circ}$ to $40^{\circ} \mathrm{N}$ and $115^{\circ}$ to $180^{\circ} \mathrm{E}$, south of ITCZ & September/October 1991 & 3 \\
\hline & $5-21$ & South Atlantic and western Indian Oceans, $0^{\circ}$ to $35.5^{\circ} \mathrm{S}$ & September/October 1992 & 4 \\
\hline & $21.0^{c}$ & Mace Head, $53.3^{\circ} \mathrm{N} 9.9^{\circ} \mathrm{W}$ & April/May 1997 & 5,6 \\
\hline & $9.3^{c}$ & Cape Grim, $40.7^{\circ} \mathrm{S} 144.7^{\circ} \mathrm{E}$ & January/February 1999 & 6 \\
\hline \multirow[t]{5}{*}{$\mathrm{C}_{3} \mathrm{H}_{6}$} & $\sim 30^{b}$ & central Pacific, $15^{\circ} \mathrm{S}$ to $20^{\circ} \mathrm{N}$ and $140^{\circ}$ to $170^{\circ} \mathrm{W}$ & February/March 1990 & 2 \\
\hline & $9.0-21.5$ & northern Pacific, $0^{\circ}$ to $40^{\circ} \mathrm{N}$ and $115^{\circ}$ to $180^{\circ} \mathrm{E}$, north of $\mathrm{ITCZ}^{d}$ & September/October 1991 & 3 \\
\hline & $2-6$ & South Atlantic and western Indian Oceans, $0^{\circ}$ to $35.5^{\circ} \mathrm{S}$ & September/October 1992 & 4 \\
\hline & $25.1^{c}$ & Mace Head, $53.3^{\circ} \mathrm{N} 9.9^{\circ} \mathrm{W}$ & April/May 1997 & 5,6 \\
\hline & $5.2^{c}$ & Cape Grim, $40.7^{\circ} \mathrm{S} 144.7^{\circ} \mathrm{E}$ & January/February 1999 & 6 \\
\hline \multirow[t]{4}{*}{$\mathrm{CH}_{3} \mathrm{CHO}$} & $\sim 80^{e}$ & tropical Pacific, $0^{\circ}$ to $30^{\circ} \mathrm{S}$ and $165^{\circ} \mathrm{E}$ to $100^{\circ} \mathrm{W}$ & March/April 1999 & 7 \\
\hline & $\sim 110^{e}$ & tropical Pacific, $0^{\circ}$ to $30^{\circ} \mathrm{N}$ and $170^{\circ}$ to $120^{\circ} \mathrm{W}$ & March/April 1999 & 7 \\
\hline & $212 \pm 29$ & equatorial Indian Ocean ${ }^{f}$ & March 1999 & 8 \\
\hline & $178 \pm 30$ & equatorial Indian Ocean ${ }^{g}$ & March 1999 & 8 \\
\hline
\end{tabular}

References: 1, Koppmann et al. (1992); 2, Donahue and Prinn (1993); 3, Gregory et al. (1996); 4, Heikes et al. (1996); 5, Lewis et al. (1999); 6, Lewis et al. (2001); 7, Singh et al. (2001); 8, Wisthaler et al. (2002).

Notes:

${ }^{a}$ Unit: $\mathrm{pmol} / \mathrm{mol}$;

${ }^{b}$ Median values;

${ }^{c}$ Average mixing ratios during 11:00-13:00 local time in the clean oceanic air as screened by backward trajectory calculations;

${ }^{d}$ No data was reported for $\mathrm{C}_{3} \mathrm{H}_{6}$ south of ITCZ;

$e$ Mean values;

${ }^{f}$ Northern Hemisphere maritime equatorial air masses;

$g$ Southern Hemisphere maritime equatorial air masses

systematic problems with canister sampling would be probable reasons for high alkene concentrations obtained in some earlier studies. Among the estimates presented in Fig. 1, those made by Plass-Dülmer et al. (1993), Thompson et al. (1993), Bonsang (1993), and Donahue and Prinn (1990) are used in our model runs. Under the mid-latitude MBL conditions the first three estimates will generally give the lowerbound to median mixing ratios of alkenes presented in Table 1, whereas the estimates by Donahue and Prinn (1990) will give $\mathrm{C}_{2} \mathrm{H}_{4}$ and $\mathrm{C}_{3} \mathrm{H}_{6}$ mixing ratios both in excess of $100 \mathrm{pmol} / \mathrm{mol}$. Although the latter situation would hardly occur in the remote MBL, resultant influence on halogen activation is noteworthy as will be shown later (see Sect. 5).

\section{Chemical mechanism development}

A number of studies have been conducted to address the tropospheric photochemistry of hydrocarbons initiated via reactions with $\mathrm{OH}, \mathrm{NO}_{3}$, and $\mathrm{O}_{3}$. Relevant kinetic and photochemical parameters for these reactions have been deter- mined by numerous experimental works and critically evaluated to give recommended values (e.g. Atkinson et al., 1997, 1999), which provide a primary basis for our chemical mechanism development. By supplementing with a protocol based on the version 3 of Master Chemical Mechanism (MCM) (Jenkin et al., 1997; Saunders et al., 2003), a near-explicit chemical mechanism describing the degradation of up to $\mathrm{C}_{3}$ hydrocarbons is constructed.

Kinetic and mechanistic details of hydrocarbon degradation initiated by halogen atoms have been poorly characterized in comparison. However, kinetic data for the reactions of $\mathrm{Cl}$ - and $\mathrm{Br}$-atoms with various low-molecular-weight hydrocarbons and their mechanistic information are becoming available (e.g. Barnes et al., 1989; Wallington et al., 1989; Bierbach et al., 1996; DeMore et al., 1997; Atkinson et al., 1997, 1999). In view of results from laboratory studies identifying reaction products, their degradation pathways are qualitatively similar to those for $\mathrm{OH}$-initiated reactions (e.g. Barnes et al., 1989; Yarwood et al., 1992; Bierbach et al., 1997). Main difficulties arise in the paucity of kinetic 
and mechanistic information on the reactions of halogencontaining organic oxygenates. They need to be estimated in the majority of cases; however, by extrapolating available information, a near-explicit description of $\mathrm{Cl}$ - and $\mathrm{Br}$-initiated degradation of up to $\mathrm{C}_{3}$-hydrocarbons is also achieved. The methodology applied in MCM helps create a protocol for such reactions as well (see Sects. S9-S10 in the electronic supplement).

Unfortunately experimental data for the aqueous-phase reactions of halogen-containing organic oxygenates are generally lacking. Hence our efforts to develop an updated chemical mechanism are placed mainly on gas-phase chemistry. The uptake of organic acids onto sea-salt aerosols is basically taken into account, although their further degradation via aqueous-phase chemistry are neglected except those for $\mathrm{HCOOH} / \mathrm{HCOO}^{-}$. The aerosol uptake of organic hydroperoxides, aldehydes, and ketones is also neglected with a few exceptions. These assumptions may not constitute major drawbacks, since the aqueous solubility of these gases is expected to be fairly low and the liquid water content of sea-salt aerosols would be too small for such compounds to exert a noticeable influence on overall chemistry.

In this section we describe how we have constructed a new chemical mechanism with an emphasis on reactions of direct relevance to the autocatalytic halogen release. Minor details of the reaction scheme including the $\mathrm{Cl}$-initiated degradation of alkenes are provided in an electronic supplement to this paper. Also given in the electronic supplement are a protocol for estimating kinetic and photochemical parameters to complement the existing experimental data, and complete listings of gas- and aqueous-phase reactions with their rate constants and of relevant parameters (Henry's law constants, mass accommodation coefficients, and equilibrium constants for ion dissociation) for multiphase reactions.

\subsection{Alkane degradation initiated by $\mathrm{Cl} / \mathrm{Br}$ atoms}

Chlorine atoms are highly reactive towards alkanes and generally their rate constants are even greater than those for analogous reactions between $\mathrm{OH}$ radicals and alkanes. The reactions will proceed via $\mathrm{H}$-abstraction from alkyl group to give $\mathrm{HCl}$ and alkyl peroxy radicals in the ambient air:

$$
\begin{aligned}
\mathrm{Cl}+\mathrm{CH}_{4} \stackrel{\mathrm{O}_{2}}{\rightarrow} \mathrm{HCl}+\mathrm{CH}_{3} \mathrm{OO} \\
\mathrm{Cl}+\mathrm{C}_{2} \mathrm{H}_{6} \stackrel{\mathrm{O}_{2}}{\rightarrow} \mathrm{HCl}+\mathrm{C}_{2} \mathrm{H}_{5} \mathrm{OO} \\
\mathrm{Cl}+\mathrm{C}_{3} \mathrm{H}_{8} \stackrel{\stackrel{\mathrm{O}_{2}}{\rightarrow}}{\rightarrow} \mathrm{HCl}+0.43 \times \mathrm{CH}_{3} \mathrm{CH}_{2} \mathrm{CH}_{2} \mathrm{OO} \\
\quad+0.57 \times \mathrm{CH}_{3} \mathrm{CH}(\mathrm{OO}) \mathrm{CH}_{3} .
\end{aligned}
$$

In the present work rate constants for these reactions are taken from those recommended by Atkinson et al. (1999). The product branching ratios of Reaction (13) are taken from experimentally determined values at $296 \mathrm{~K}$ (Tyndall et al., 1997).

Alkyl peroxy radicals thus produced will undergo further degradation following the same pathways as those pro- duced via $\mathrm{OH}$-initiated alkane oxidations. Among the degradation products a series of aldehydes, $\mathrm{HCHO}, \mathrm{CH}_{3} \mathrm{CHO}$, and $\mathrm{C}_{2} \mathrm{H}_{5} \mathrm{CHO}$, is most noteworthy in terms of autocatalytic halogen release from sea-salt aerosols, since these compounds react quite rapidly with $\mathrm{Br}$ atoms to give relatively stable $\mathrm{HBr}$ :

$$
\begin{aligned}
& \mathrm{Br}+\mathrm{HCHO} \stackrel{\mathrm{O}_{2}}{\rightarrow} \mathrm{HBr}+\mathrm{CO}+\mathrm{HO}_{2} \\
& \mathrm{Br}+\mathrm{CH}_{3} \mathrm{CHO} \stackrel{\mathrm{O}_{2}}{\rightarrow} \mathrm{HBr}+\mathrm{CH}_{3} \mathrm{C}(\mathrm{O}) \mathrm{OO} \\
& \mathrm{Br}+\mathrm{C}_{2} \mathrm{H}_{5} \mathrm{CHO} \stackrel{\mathrm{O}_{2}}{\rightarrow} \mathrm{HBr}+\mathrm{C}_{2} \mathrm{H}_{5} \mathrm{C}(\mathrm{O}) \mathrm{OO} .
\end{aligned}
$$

It should be noted that rate constants for these reactions become progressively greater as the carbon number of alkyl group increases: $k_{15} / k_{14}=3.60 \pm 0.29$ and $k_{16} / k_{14}=6.65 \pm 0.53$ over the temperature range $240-300 \mathrm{~K}$ (Ramacher et al., 2000). In view of recent observational data for the mixing ratios of HCHO (ca. $300 \mathrm{pmol} / \mathrm{mol}$ ) and $\mathrm{CH}_{3} \mathrm{CHO}$ (ca. $90 \mathrm{pmol} / \mathrm{mol}$ ) in the remote Pacific lower troposphere (Singh et al., 2001), $\mathrm{CH}_{3} \mathrm{CHO}$ is suggested as important as $\mathrm{HCHO}$ for impeding autocatalytic halogen release in the MBL (see Sect. 5.2 for further discussion).

Reactions between $\mathrm{Br}$ atoms and low-molecular-weight alkanes proceed so slow at atmospheric temperatures that they are of negligible importance in the atmosphere (Russell et al., 1988). Thus the reactions of $\mathrm{Br}$ atoms with $\mathrm{CH}_{4}$, $\mathrm{C}_{2} \mathrm{H}_{6}$, and $\mathrm{C}_{3} \mathrm{H}_{8}$ are neglected in our reaction scheme.

\subsection{Alkene degradation initiated by $\mathrm{Br}$ atoms}

\subsubsection{Br-atom attacks on alkenes}

The reactions $\mathrm{Br}+\mathrm{C}_{2} \mathrm{H}_{4} / \mathrm{C}_{3} \mathrm{H}_{6}$ will proceed predominantly via the addition channels to give brominated alkyl peroxy radicals in the ambient air (Bedjanian et al., 1998, 1999, see also Sect. S2 in the electronic supplement):

$$
\begin{aligned}
\mathrm{Br}+\mathrm{C}_{2} \mathrm{H}_{4} \stackrel{\mathrm{M}_{4}, \mathrm{O}_{2}}{\rightarrow} & \mathrm{BrCH}_{2} \mathrm{CH}_{2} \mathrm{OO} \\
\mathrm{Br}+\mathrm{C}_{3} \mathrm{H}_{6} \stackrel{\mathrm{M}^{\prime} \mathrm{O}_{2}}{\rightarrow} & 0.87 \times \mathrm{CH}_{3} \mathrm{CH}(\mathrm{OO}) \mathrm{CH}_{2} \mathrm{Br} \\
& +0.13 \times \mathrm{CH}_{3} \mathrm{CHBrCH}_{2} \mathrm{OO}
\end{aligned}
$$

where the product branching ratios of Reaction (18) are assigned by analogy with $\mathrm{Cl}$-atom addition to $\mathrm{C}_{3} \mathrm{H}_{6}$ (see Sect. S4 in the electronic supplement). In the present work, the rate constant for Reaction (17) is taken from Ramacher et al. (2001) and that for Reaction (18) is obtained by averaging two independent experimental data (Barnes et al., 1989; Wallington et al., 1989). It is important to note that the rate constant of Reaction (18) is approximately 20 times greater than that of Reaction (17) in $1 \mathrm{~atm}$ of air. The rate constant of $\mathrm{H}$-abstraction from the methyl group by $\mathrm{Br}$ atoms has also been determined experimentally (Bedjanian et al., 1998):

$\mathrm{Br}+\mathrm{C}_{3} \mathrm{H}_{6} \stackrel{\mathrm{O}_{2}}{\rightarrow} \mathrm{HBr}+\mathrm{CH}_{2}=\mathrm{CHCH}_{2} \mathrm{OO}$,

although the probability of this channel in the overall reaction $\mathrm{Br}+\mathrm{C}_{3} \mathrm{H}_{6}$ is less than $1 \%$ in $1 \mathrm{~atm}$ of air. 
As described below, an experimental basis is only partially available for characterizing the kinetic and mechanistic details of complete reaction pathways that follow Reactions (17)-(18). Hence, where experimental data do not exist, empirical methods are employed for estimating the rate constants and products of reactions as described in Sects. S9$\mathrm{S} 10$ in the electronic supplement. In particular, kinetics and mechanisms are virtually completely estimated concerning the $\mathrm{CH}_{3} \mathrm{CHBrCH}_{2} \mathrm{OO}$-branch of $\mathrm{C}_{3} \mathrm{H}_{6}$ degradation initiated via Reaction (18).

3.2.2 Reactions of brominated alkyl peroxy and alkoxy radicals

Yarwood et al. (1992) performed an FTIR product study for UV-irradiated $\mathrm{Br}_{2} / \mathrm{C}_{2} \mathrm{H}_{4}$ /air mixtures and identified $\mathrm{BrCH}_{2} \mathrm{CHO}, \mathrm{BrCH}_{2} \mathrm{CH}_{2} \mathrm{OOH}$, and $\mathrm{BrCH}_{2} \mathrm{CH}_{2} \mathrm{OH}$ as main degradation products where secondary reactions are minimized. This implies that $\mathrm{BrCH}_{2} \mathrm{CH}_{2} \mathrm{OO}$ formed via Reaction (17) will undergo qualitatively similar reactions to those of simple peroxy radicals such as $\mathrm{CH}_{3} \mathrm{OO}$. Hence reactions with either $\mathrm{NO}, \mathrm{HO}_{2}$, or $\mathrm{CH}_{3} \mathrm{OO}$ are the most likely fate of $\mathrm{BrCH}_{2} \mathrm{CH}_{2} \mathrm{OO}$ in the ambient air:

$$
\begin{aligned}
& \mathrm{BrCH}_{2} \mathrm{CH}_{2} \mathrm{OO}+\mathrm{NO} \rightarrow \mathrm{BrCH}_{2} \mathrm{CH}_{2} \mathrm{O}^{*}+\mathrm{NO}_{2} \\
& \mathrm{BrCH}_{2} \mathrm{CH}_{2} \mathrm{OO}+\mathrm{HO}_{2} \rightarrow \mathrm{BrCH}_{2} \mathrm{CH}_{2} \mathrm{OOH}+\mathrm{O}_{2} \\
& \mathrm{BrCH}_{2} \mathrm{CH}_{2} \mathrm{OO}+\mathrm{CH}_{3} \mathrm{OO} \\
& \rightarrow 0.44 \times\left(\mathrm{BrCH}_{2} \mathrm{CH}_{2} \mathrm{O}+\mathrm{CH}_{3} \mathrm{O}+\mathrm{O}_{2}\right) \\
& \quad+0.28 \times\left(\mathrm{BrCH}_{2} \mathrm{CHO}+\mathrm{CH}_{3} \mathrm{OH}+\mathrm{O}_{2}\right) \\
& \quad+0.28 \times\left(\mathrm{BrCH}_{2} \mathrm{CH}_{2} \mathrm{OH}+\mathrm{HCHO}+\mathrm{O}_{2}\right) .
\end{aligned}
$$

Kinetic and mechanistic data, however, do not exist for these reactions and thus need to be estimated as described in Sect. S9 in the electronic supplement. It should be noted that the kinetic and mechanistic nature of Reactions (20)(22) is assumed basically identical to that of analogous reactions involving $\mathrm{ClCH}_{2} \mathrm{CH}_{2} \mathrm{OO}$ (see also Sects. $\mathrm{S} 1$ and $\mathrm{S} 9$ in the electronic supplement).

By analogy with the fate of $\mathrm{HOCH}_{2} \mathrm{CH}_{2} \mathrm{O}$ radicals produced via $\mathrm{OH}$-initiated $\mathrm{C}_{2} \mathrm{H}_{4}$ oxidation, alkoxy radicals ( $\mathrm{BrCH}_{2} \mathrm{CH}_{2} \mathrm{O}^{*}$ and $\mathrm{BrCH}_{2} \mathrm{CH}_{2} \mathrm{O}$ ) formed via Reactions (20) and (22) can either decompose to give $\mathrm{BrCH}_{2}+\mathrm{HCHO}$ or react with $\mathrm{O}_{2}$ to give $\mathrm{BrCH}_{2} \mathrm{CHO}+\mathrm{HO}_{2}$. However, in view of fairly good mass balance between $\mathrm{C}_{2} \mathrm{H}_{4}$ reacted and the three main products containing bromine in the experiments performed by Yarwood et al. (1992), it is quite likely that $\mathrm{BrCH}_{2} \mathrm{CH}_{2} \mathrm{O}$ radicals formed via Reaction (22) exclusively react with $\mathrm{O}_{2}$ :

$\mathrm{BrCH}_{2} \mathrm{CH}_{2} \mathrm{O}+\mathrm{O}_{2} \rightarrow \mathrm{BrCH}_{2} \mathrm{CHO}+\mathrm{HO}_{2}$.

On the other hand, recent experimental studies identified several examples for chlorinated and/or brominated alkoxy radicals produced via reactions between their parent peroxy radicals and NO to decompose before thermalized, since alkoxy radicals thus produced will possess internal excitation due to the exothermicity of reactions (Bilde et al., 1998, 1999; Orlando et al., 1998). However, it is completely unknown whether Reaction (20) gives internally excited $\mathrm{BrCH}_{2} \mathrm{CH}_{2} \mathrm{O}^{*}$, since previous product studies for $\mathrm{Br}$ initiated $\mathrm{C}_{2} \mathrm{H}_{4}$ degradation have not been conducted with added NO to facilitate Reaction (20) (Barnes et al., 1989; Yarwood et al., 1992). The fate of $\mathrm{BrCH}_{2} \mathrm{CH}_{2} \mathrm{O}^{*}$, if formed, is also unknown. In the present work it is tentatively assumed that Reaction (20) does give $\mathrm{BrCH}_{2} \mathrm{CH}_{2} \mathrm{O}^{*}$ and that the further degradation of $\mathrm{BrCH}_{2} \mathrm{CH}_{2} \mathrm{O}^{*}$ occurs analogously to that of $\mathrm{ClCH}_{2} \mathrm{CH}_{2} \mathrm{O}^{*}$ (see Sect. $\mathrm{S} 1$ in the electronic supplement):

$$
\begin{gathered}
\mathrm{BrCH}_{2} \mathrm{CH}_{2} \mathrm{O}^{*} \stackrel{\mathrm{O}_{2}}{\rightarrow} 0.58 \times\left(\mathrm{BrCH}_{2} \mathrm{CHO}+\mathrm{HO}_{2}\right) \\
+0.42 \times\left(\mathrm{BrCH}_{2} \mathrm{OO}+\mathrm{HCHO}\right) .
\end{gathered}
$$

As with $\mathrm{BrCH}_{2} \mathrm{CH}_{2} \mathrm{OO}, \mathrm{CH}_{3} \mathrm{CH}(\mathrm{OO}) \mathrm{CH}_{2} \mathrm{Br}$ radicals formed via Reaction (18) will undergo reactions with $\mathrm{NO}$, $\mathrm{HO}_{2}$, or $\mathrm{CH}_{3} \mathrm{OO}$ in the ambient air. Again, however, their rate constants need to be estimated as described in Sect. S9 in the electronic supplement:

$$
\begin{aligned}
& \mathrm{CH}_{3} \mathrm{CH}(\mathrm{OO}) \mathrm{CH}_{2} \mathrm{Br}+\mathrm{NO} \\
& \quad \rightarrow \mathrm{CH}_{3} \mathrm{CH}(\mathrm{O}) \mathrm{CH}_{2} \mathrm{Br}^{*}+\mathrm{NO}_{2} \\
& \quad \mathrm{CH}_{3} \mathrm{CH}(\mathrm{OO}) \mathrm{CH}_{2} \mathrm{Br}+\mathrm{HO}_{2} \\
& \quad \rightarrow \mathrm{CH}_{3} \mathrm{CH}(\mathrm{OOH}) \mathrm{CH}_{2} \mathrm{Br}+\mathrm{O}_{2} \\
& \mathrm{CH}_{3} \mathrm{CH}(\mathrm{OO}) \mathrm{CH}_{2} \mathrm{Br}+\mathrm{CH}_{3} \mathrm{OO} \\
& \rightarrow 0.6 \times\left(\mathrm{CH}_{3} \mathrm{CH}(\mathrm{O}) \mathrm{CH}_{2} \mathrm{Br}+\mathrm{CH}_{3} \mathrm{O}+\mathrm{O}_{2}\right) \\
& \quad+0.2 \times\left(\mathrm{CH}_{3} \mathrm{COCH}{ }_{2} \mathrm{Br}+\mathrm{CH}_{3} \mathrm{OH}+\mathrm{O}_{2}\right) \\
& \quad+0.2 \times\left(\mathrm{CH}_{3} \mathrm{CH}(\mathrm{OH}) \mathrm{CH}_{2} \mathrm{Br}+\mathrm{HCHO}+\mathrm{O}_{2}\right)
\end{aligned}
$$

where the product branching ratios of Reaction (27) are taken from generic values assigned in the work of MCM (Jenkin et al., 1997). To date no experimental study has been performed in an attempt to resolve complete pathways of $\mathrm{Br}$ initiated $\mathrm{C}_{3} \mathrm{H}_{6}$ degradation. Impey et al. (1997), however, determined the yield of bromoacetone $\left(\mathrm{CH}_{3} \mathrm{COCH}_{2} \mathrm{Br}\right)$ from the reaction $\mathrm{Br}+\mathrm{C}_{3} \mathrm{H}_{6}$ in NO-rich air to be 0.75 . From their data and our assumed product branching ratios for Reaction (18), it is estimated that $\mathrm{CH}_{3} \mathrm{CH}(\mathrm{O}) \mathrm{CH}_{2} \mathrm{Br}^{*}$ radicals undergo decomposition and reaction with $\mathrm{O}_{2}$ with the branching ratios of 0.14 and 0.86 , respectively:

$$
\begin{aligned}
& \mathrm{CH}_{3} \mathrm{CH}(\mathrm{O}) \mathrm{CH}_{2} \mathrm{Br}^{*} \rightarrow \stackrel{\mathrm{CH}_{3} \mathrm{CHO}+\mathrm{BrCH}_{2}}{ } \\
& \stackrel{\mathrm{O}_{2}}{\rightarrow} \mathrm{CH}_{3} \mathrm{CHO}+\mathrm{BrCH}_{2} \mathrm{OO} \\
& \mathrm{CH}_{3} \mathrm{CH}(\mathrm{O}) \mathrm{CH}_{2} \mathrm{Br}^{*}+\mathrm{O}_{2} \rightarrow \mathrm{CH}_{3} \mathrm{COCH}_{2} \mathrm{Br}+\mathrm{HO}_{2} .
\end{aligned}
$$

$\mathrm{CH}_{3} \mathrm{CH}(\mathrm{O}) \mathrm{CH}_{2} \mathrm{Br}$ radicals formed via Reaction (27) are assumed to undergo the same fate as above, since no experimental data exist to rule out this assumption. Actually, analogous reactions for 3-bromo-2-butoxy $\left(\mathrm{CH}_{3} \mathrm{CH}(\mathrm{O}) \mathrm{CHBrCH}_{3}\right)$ radicals were investigated by Bierbach et al. (1997) in their FTIR product study of $\mathrm{Br}$ initiated oxidation of trans- $2-\mathrm{C}_{4} \mathrm{H}_{8}$ in 1000 mbar air. 
At $298 \mathrm{~K}$ approximately $40 \%$ of $\mathrm{CH}_{3} \mathrm{CH}(\mathrm{O}) \mathrm{CHBrCH}_{3}$ radicals were found to undergo decomposition to give $\mathrm{CH}_{3} \mathrm{CHO}+\mathrm{CH}_{3} \mathrm{CHBr}$ rather than reaction with $\mathrm{O}_{2}$ to give $\mathrm{CH}_{3} \mathrm{COCHBrCH}_{3}+\mathrm{HO}_{2}$, whether $\mathrm{NO}$ is added or not to the reaction system.

The reactions of $\mathrm{BrCH}_{2} \mathrm{OO}$ have been characterized relatively well. Rate constants and product branching ratios for its reactions with $\mathrm{NO}, \mathrm{HO}_{2}$, and itself have been measured or derived experimentally (Sehested et al., 1993; Chen et al., 1995; Villenave and Lesclaux, 1995). Such information well delineates the fate of $\mathrm{BrCH}_{2} \mathrm{OO}$ in the ambient air:

$$
\begin{aligned}
\mathrm{BrCH}_{2} \mathrm{OO}+\mathrm{NO} \rightarrow \mathrm{BrCH}_{2} \mathrm{O}^{*}+\mathrm{NO}_{2} \\
\mathrm{BrCH}_{2} \mathrm{OO}+\mathrm{HO}_{2} \rightarrow 0.9 \times\left(\mathrm{BrCH}_{2} \mathrm{OOH}+\mathrm{O}_{2}\right) \\
+0.1 \times\left(\mathrm{HCOBr}+\mathrm{H}_{2} \mathrm{O}+\mathrm{O}_{2}\right) \\
\mathrm{BrCH}_{2} \mathrm{OO}+\mathrm{CH}_{3} \mathrm{OO} \\
\rightarrow 0.65 \times\left(\mathrm{BrCH}_{2} \mathrm{O}+\mathrm{CH}_{3} \mathrm{O}+\mathrm{O}_{2}\right) \\
+0.35 \times\left(\mathrm{BrCH}_{2} \mathrm{OH}+\mathrm{HCHO}+\mathrm{O}_{2}\right)
\end{aligned}
$$

where the rate constant and branching ratios of Reaction (32) are estimated as described in Sect. S9 in the electronic supplement. Alkoxy radicals $\left(\mathrm{BrCH}_{2} \mathrm{O}^{*}\right.$ and $\left.\mathrm{BrCH}_{2} \mathrm{O}\right)$ formed via Reactions (30) and (32) will then mostly undergo decomposition in the ambient air (Chen et al., 1995; Orlando et al., 1996). In the present work, $\mathrm{BrCH}_{2} \mathrm{O}^{*}$ radicals are assumed to exclusively undergo decomposition:

$\mathrm{BrCH}_{2} \mathrm{O}^{*} \rightarrow \mathrm{HCHO}+\mathrm{Br}$,

whereas $\mathrm{BrCH}_{2} \mathrm{O}$ radicals are assumed not only to undergo decomposition but also to react with $\mathrm{O}_{2}$ :

$\mathrm{BrCH}_{2} \mathrm{O} \rightarrow \mathrm{HCHO}+\mathrm{Br}$

$\mathrm{BrCH}_{2} \mathrm{O}+\mathrm{O}_{2} \rightarrow \mathrm{HCOBr}+\mathrm{HO}_{2}$

where $\quad k_{34}=3 \times 10^{7} \mathrm{~s}^{-1}$

and $k_{35}=6 \times 10^{-14} \mathrm{~cm}^{3}$ molecule ${ }^{-1} \mathrm{~s}^{-1}$, respectively (Orlando et al., 1996). It follows that approximately $99 \%$ of $\mathrm{BrCH}_{2} \mathrm{O}$ loss occurs via Reaction (34) in $1 \mathrm{~atm}$ of air (see Sect. S3 in the electronic supplement for further discussion).

3.2.3 Further degradation of brominated organic intermediates

As described above, Br-attacks on alkenes will result in producing a variety of brominated organic intermediates taking the forms of carbonyl, hydroperoxide, and alcohol in the ambient air. In the present work, kinetics and mechanisms of their further degradation are also carefully evaluated.

In the ambient air $\mathrm{BrCH}_{2} \mathrm{CHO}$ will be destroyed via either photolysis or $\mathrm{OH}$ attack:

$$
\begin{aligned}
\mathrm{BrCH}_{2} \mathrm{CHO}+h v \rightarrow & \mathrm{BrCH}_{2}+\mathrm{HCO} \\
& \stackrel{\mathrm{O}_{2}}{\rightarrow} \mathrm{BrCH}_{2} \mathrm{OO}+\mathrm{CO}+\mathrm{HO}_{2} \\
\rightarrow & \mathrm{CH}_{3} \mathrm{Br}+\mathrm{CO} \\
\mathrm{BrCH}_{2} \mathrm{CHO}+\mathrm{OH} \rightarrow & \mathrm{BrCH}_{2} \mathrm{CO}+\mathrm{H}_{2} \mathrm{O}
\end{aligned}
$$

where the rate constant for Reaction (38) as well as absorption cross sections and quantum yields for $\mathrm{BrCH}_{2} \mathrm{CHO}$ photolysis need to be estimated as described in Sect. S10 in the electronic supplement. By analogy with $\mathrm{CH}_{3} \mathrm{CHO}$ photolysis, the formation of $\mathrm{CH}_{3} \mathrm{Br}+\mathrm{CO}$, i.e. Reaction (37), is assumed to occur as a minor channel of $\mathrm{BrCH}_{2} \mathrm{CHO}$ photolysis (see Sect. S10 for details). $\mathrm{BrCH}_{2} \mathrm{CO}$ radicals formed via Reaction (38) will be lost via three different pathways:

$$
\begin{aligned}
& \mathrm{BrCH}_{2} \mathrm{CO}+\mathrm{O}_{2} \stackrel{\mathrm{M}}{\rightarrow} \mathrm{BrCH}_{2} \mathrm{C}(\mathrm{O}) \mathrm{OO} \\
& \mathrm{BrCH}_{2} \mathrm{CO} \stackrel{\mathrm{M}}{\rightarrow} \mathrm{BrCH}_{2}+\mathrm{CO} \stackrel{\mathrm{O}_{2}}{\rightarrow} \mathrm{BrCH}_{2} \mathrm{OO}+\mathrm{CO} \\
& \stackrel{\mathrm{M}}{\rightarrow} \mathrm{Br}+\mathrm{CH}_{2}=\mathrm{CO}
\end{aligned}
$$

where the branching ratios of Reactions (39), (40), and (41) are $0.5,0.25$, and 0.25 , respectively, at $297 \mathrm{~K}$ in 700 Torr of air (Chen et al., 1996). $\mathrm{BrCH}_{2} \mathrm{C}(\mathrm{O}) \mathrm{OO}$ radicals thus produced will undergo reactions analogous to those of $\mathrm{CH}_{3} \mathrm{C}(\mathrm{O}) \mathrm{OO}$ to give products such as $\mathrm{BrCH}_{2}(\mathrm{O}) \mathrm{OONO}_{2}$ ( $\mathrm{PBrAN}), \mathrm{BrCH}_{2} \mathrm{COOH}$, and $\mathrm{BrCH}_{2} \mathrm{C}(\mathrm{O}) \mathrm{OOH}$ :

$$
\begin{aligned}
& \mathrm{BrCH}_{2} \mathrm{C}(\mathrm{O}) \mathrm{OO}+\mathrm{NO}_{2} \stackrel{\mathrm{M}}{\rightleftharpoons} \mathrm{BrCH}_{2}(\mathrm{O}) \mathrm{OONO}_{2} \\
& \mathrm{BrCH}_{2} \mathrm{C}(\mathrm{O}) \mathrm{OO}+\mathrm{NO} \stackrel{\mathrm{O}_{2}}{\rightarrow} \mathrm{BrCH}_{2} \mathrm{OO}+\mathrm{CO}_{2}+\mathrm{NO}_{2} \\
& \mathrm{BrCH}_{2} \mathrm{C}(\mathrm{O}) \mathrm{OO}+\mathrm{HO}_{2} \rightarrow \\
& \quad 0.71 \times\left(\mathrm{BrCH}_{2} \mathrm{C}(\mathrm{O}) \mathrm{OOH}+\mathrm{O}_{2}\right) \\
& \quad+0.29 \times\left(\mathrm{BrCH}_{2} \mathrm{COOH}+\mathrm{O}_{3}\right) \\
& \mathrm{BrCH}_{2} \mathrm{C}(\mathrm{O}) \mathrm{OO}+\mathrm{CH}_{3} \mathrm{OO} \stackrel{\mathrm{O}_{2}}{\rightarrow} \\
& \quad 0.7 \times\left(\mathrm{BrCH}_{2} \mathrm{OO}+\mathrm{CO}_{2}+\mathrm{HCHO}+\mathrm{HO}_{2}+\mathrm{O}_{2}\right) \\
& \quad+0.3 \times\left(\mathrm{BrCH}_{2} \mathrm{COOH}+\mathrm{HCHO}+\mathrm{O}_{2}\right) .
\end{aligned}
$$

The formation of these compounds has been verified experimentally: $\mathrm{PBrAN}$ formed from $\mathrm{Br}$-atom initiated oxidation of $\mathrm{BrCH}_{2} \mathrm{CHO}$ in $\mathrm{NO}_{2}$-rich air (Chen et al., 1996); $\mathrm{BrCH}_{2} \mathrm{COOH}$ and possibly $\mathrm{BrCH}_{2} \mathrm{C}(\mathrm{O}) \mathrm{OOH}$ formed from Br-atom initiated oxidation of $\mathrm{C}_{2} \mathrm{H}_{4}$ in air without added $\mathrm{NO}_{2}$ (Barnes et al., 1989). However, the rate constants and product yields of Reactions (42)-(45) are unknown and thus assumed identical to those of analogous reactions involving $\mathrm{CH}_{3} \mathrm{C}(\mathrm{O}) \mathrm{OO}$ radicals.

$\mathrm{CH}_{3} \mathrm{COCH}_{2} \mathrm{Br}$ will be destroyed via either photolysis or $\mathrm{OH}$ attack in the ambient air. Based on experimentally determined data for the absorption cross sections of $\mathrm{CH}_{3} \mathrm{COCH}_{2} \mathrm{Br}$ and quantum yields for its photolysis (Burkholder et al., 2002), the lifetime of $\mathrm{CH}_{3} \mathrm{COCH}_{2} \mathrm{Br}$ against photolysis is estimated to be less than half a day in the mid-latitude MBL (see Table S4):

$$
\begin{aligned}
& \mathrm{CH}_{3} \mathrm{COCH}_{2} \mathrm{Br}+h v \stackrel{\mathrm{O}_{2}}{\rightarrow} \mathrm{CH}_{3} \mathrm{C}(\mathrm{O}) \mathrm{OO}+\mathrm{BrCH}_{2} \mathrm{OO} \\
& \stackrel{\mathrm{O}_{2}}{\rightarrow} \mathrm{CH}_{3} \mathrm{OO}+\mathrm{BrCH}_{2} \mathrm{CO} \text {. }
\end{aligned}
$$

$\mathrm{BrCH}_{2} \mathrm{OO}$ and $\mathrm{BrCH}_{2} \mathrm{CO}$ radicals will then undergo Reactions (30)-(32) and Reactions (39)-(41), respectively. The 
$\mathrm{OH}$ attack on $\mathrm{CH}_{3} \mathrm{COCH}_{2} \mathrm{Br}$, whose rate constant is estimated as described in Sect. S10 in the electronic supplement, will take place much slower than photolysis.

Based on the absorption cross sections data obtained by Libuda (1992) with the assumption of unit quantum yield, the lifetime of $\mathrm{HCOBr}$ against photolysis is estimated to be about 6.5 days in the mid-latitude MBL (see Table S4 in the electronic supplement):

$\mathrm{HCOBr}+h v \stackrel{\mathrm{O}_{2}}{\rightarrow} \mathrm{Br}+\mathrm{CO}+\mathrm{HO}_{2}$

Although the rate constants of $\mathrm{OH}-$ and $\mathrm{Cl}$-attacks against $\mathrm{HCOBr}$ are unknown at the present time, they are quite likely similar to those of $\mathrm{OH}-$ and $\mathrm{Cl}$-attacks against $\mathrm{HCOCl}$ (resultant lifetime will be longer than 45 days; see Sect. S1 in the electronic supplement) and therefore of minor importance compared with $\mathrm{HCOBr}$ photolysis. On the other hand, previous experimental studies reported that $\mathrm{HCOBr}$ is highly susceptible to a wall reaction on the chamber surface to give $\mathrm{HBr}+\mathrm{CO}$ (Weller et al., 1992; Chen et al., 1995; Orlando et al., 1996). An analogous wall reaction of $\mathrm{HCOCl}$ also takes place on the chamber surface (Libuda et al., 1990; Kaiser and Wallington, 1994; Wallington et al., 1996). On the basis of experimental evidence that non-hydrolytic decay of $\mathrm{HCOCl}$ to give $\mathrm{HCl}+\mathrm{CO}$ occurs quite rapidly in aqueous solutions (Dowideit et al., 1996), the reactive uptake coefficient of $\mathrm{HCOCl}$ on the surface of sea-salt aerosols is estimated to be 0.1 in the present work (see further discussion in Sect. S1 in the electronic supplement). The same uptake coefficient is assumed to apply to $\mathrm{HCOBr}$, constraining its lifetime in the MBL to be on the order of hours.

Brominated hydroperoxides (e.g. $\mathrm{CH}_{3} \mathrm{CH}(\mathrm{OOH}) \mathrm{CH}_{2} \mathrm{Br}$, $\mathrm{BrCH}_{2} \mathrm{CH}_{2} \mathrm{OOH}$, and $\mathrm{BrCH}_{2} \mathrm{OOH}$ ) will be destroyed via either $\mathrm{OH}$ attacks or photolysis, although no experimental data exist for these reactions. For instance, the following pathways are included for $\mathrm{BrCH}_{2} \mathrm{CH}_{2} \mathrm{OOH}$ loss in the present reaction scheme:

$$
\begin{aligned}
& \mathrm{OH}+\mathrm{BrCH}_{2} \mathrm{CH}_{2} \mathrm{OOH} \\
& \rightarrow \mathrm{H}_{2} \mathrm{O}+\mathrm{BrCH}_{2} \mathrm{CH}_{2} \mathrm{OO} \\
& \rightarrow \mathrm{H}_{2} \mathrm{O}+\mathrm{BrCH}_{2} \mathrm{CHO}+\mathrm{OH} \\
& \mathrm{BrCH}_{2} \mathrm{CH}_{2} \mathrm{OOH}+h v \rightarrow \mathrm{BrCH}_{2} \mathrm{CH}_{2} \mathrm{O}+\mathrm{OH}
\end{aligned}
$$

where rate constants or J values for Reactions (49)-(51) are estimated as described in Sect. S10 in the electronic supplement. Actually, the $\mathrm{OH}$ attack on $\mathrm{BrCH}_{2} \mathrm{CH}_{2} \mathrm{OOH}$ may have an additional channel to give $\mathrm{BrCHCH}_{2} \mathrm{OOH}+\mathrm{H}_{2} \mathrm{O}$. It is estimated, however, of minor importance compared with channels (49)-(50), and therefore neglected in the present work. The rate constant of Reaction (50) is then scaled to maintain the overall rate of the $\mathrm{OH}$ attack (see Sect. S10 in the electronic supplement).

Finally, brominated alcohols (e.g. $\mathrm{CH}_{3} \mathrm{CH}(\mathrm{OH}) \mathrm{CH}_{2} \mathrm{Br}$, $\mathrm{BrCH}_{2} \mathrm{CH}_{2} \mathrm{OH}$, and $\mathrm{BrCH}_{2} \mathrm{OH}$ ) will be destroyed via reactions with $\mathrm{OH}$ radicals to yield brominated carbonyl compounds of the same carbon number as parent alcohols. As in the case of brominated hydroperoxides, the rate constants of the reactions are estimated and channels of minor importance are neglected as described in Sect. S10 in the electronic supplement. $\mathrm{BrCH}_{2} \mathrm{OH}$ is also quite likely to undergo rapid unimolecular decomposition to give $\mathrm{HCHO}+\mathrm{HBr}$ by analogy with $\mathrm{ClCH}_{2} \mathrm{OH}$ (Tyndall et al., 1993).

\section{3 $\mathrm{C}_{2} \mathrm{H}_{2}$ degradation initiated by $\mathrm{Cl} / \mathrm{Br}$ atoms}

Rate constants for the reactions $\mathrm{Cl} / \mathrm{Br}+\mathrm{C}_{2} \mathrm{H}_{2}$ have been measured by several workers. In the present work, parameters to yield the pseudo-second-order rate constant for the reaction $\mathrm{Cl}+\mathrm{C}_{2} \mathrm{H}_{2}$ are taken from recommended values given by Atkinson et al. (1999), whereas the second-order rate constant for the reaction $\mathrm{Br}+\mathrm{C}_{2} \mathrm{H}_{2}$ measured over $239-296 \mathrm{~K}$ in 700 Torr air (Ramacher et al., 2001) is fitted in the Arrhenius form. The branching ratios of reactions $\mathrm{Br} / \mathrm{Cl}+\mathrm{C}_{2} \mathrm{H}_{2}$ are taken from the values as derived in the FTIR product study performed by Yarwood et al. (1991) at $296 \mathrm{~K}$ in 700 Torr air (see Sect. S6 in the electronic supplement for further discussion):

$$
\begin{aligned}
\mathrm{Cl}+\mathrm{C}_{2} \mathrm{H}_{2} \stackrel{{\mathrm{M}, \mathrm{O}_{2}}}{\rightarrow} & 0.26 \times\left(\mathrm{HCOCl}+\mathrm{CO}+\mathrm{HO}_{2}\right) \\
& +0.21 \times(\mathrm{HCOCHO}+\mathrm{Cl}) \\
& +0.53 \times\left(\mathrm{HCl}+2 \mathrm{CO}+\mathrm{HO}_{2}\right) \\
\mathrm{Br}+\mathrm{C}_{2} \mathrm{H}_{2} \stackrel{\mathrm{M}^{\circ} \mathrm{O}_{2}}{\rightarrow} & 0.17 \times\left(\mathrm{HCOBr}+\mathrm{CO}+\mathrm{HO}_{2}\right) \\
+ & 0.09 \times(\mathrm{HCOCHO}+\mathrm{Br}) \\
+ & 0.74 \times\left(\mathrm{HBr}+2 \mathrm{CO}+\mathrm{HO}_{2}\right) .
\end{aligned}
$$

3.4 Aqueous-phase reactions of peroxyacetic acid (PAA)

Reactions of $\mathrm{OH} / \mathrm{NO}_{3} / \mathrm{Br} / \mathrm{Cl}$ with $\mathrm{CH}_{3} \mathrm{CHO}$ will proceed predominantly via abstraction of aldehydic-H to give $\mathrm{CH}_{3} \mathrm{C}(\mathrm{O}) \mathrm{OO}$ radicals in the ambient air (Atkinson et al., 1999):

$\mathrm{X}+\mathrm{CH}_{3} \mathrm{CHO} \stackrel{\mathrm{O}_{2}}{\rightarrow} \mathrm{HX}+\mathrm{CH}_{3} \mathrm{C}(\mathrm{O}) \mathrm{OO}$

where $\mathrm{X}$ is either $\mathrm{OH}, \mathrm{NO}_{3}, \mathrm{Br}$, or $\mathrm{Cl}$. In the remote MBL where $\mathrm{NO}_{\mathrm{x}}$ concentrations are relatively low, a fairly large fraction of $\mathrm{CH}_{3} \mathrm{C}(\mathrm{O}) \mathrm{OO}$ radicals will react with $\mathrm{HO}_{2} / \mathrm{CH}_{3} \mathrm{OO}$ radicals rather than with $\mathrm{NO}_{\mathrm{x}}$ to give $\mathrm{CH}_{3} \mathrm{C}(\mathrm{O}) \mathrm{OOH}$ (peroxyacetic acid, or PAA) and/or $\mathrm{CH}_{3} \mathrm{COOH}$ (Jenkin et al., 1997; Atkinson et al., 1999; Saunders et al., 2003):

$$
\begin{aligned}
& \mathrm{CH}_{3} \mathrm{C}(\mathrm{O}) \mathrm{OO}+\mathrm{HO}_{2} \rightarrow 0.71 \times\left(\mathrm{PAA}+\mathrm{O}_{2}\right) \\
& \quad+0.29 \times\left(\mathrm{CH}_{3} \mathrm{COOH}+\mathrm{O}_{3}\right) \\
& \mathrm{CH}_{3} \mathrm{C}(\mathrm{O}) \mathrm{OO}+\mathrm{CH}_{3} \mathrm{OO} \stackrel{\mathrm{O}_{2}}{\rightarrow} \\
& \quad 0.7 \times\left(\mathrm{CH}_{3} \mathrm{OO}+\mathrm{CO}_{2}+\mathrm{HCHO}+\mathrm{HO}_{2}+\mathrm{O}_{2}\right) \\
& \quad+0.3 \times\left(\mathrm{CH}_{3} \mathrm{COOH}+\mathrm{HCHO}+\mathrm{O}_{2}\right) .
\end{aligned}
$$

Henry's law constants and acid dissociation constants in water have been determined experimentally for both 
$\mathrm{CH}_{3} \mathrm{COOH}$ and PAA so that their uptake onto sea-salt aerosols can be simulated quite reasonably. In addition, rate coefficients for the aqueous-phase oxidation of S(IV) and $\mathrm{Br}^{-}$by PAA have been experimentally determined (Fortnum et al., 1960; Lind et al., 1987), allowing the quantitative estimates of their impacts:

$\mathrm{HSO}_{3}^{-}+\mathrm{PAA}^{\mathrm{H}} \rightarrow \mathrm{SO}_{4}^{2-}+2 \mathrm{H}^{+}+\mathrm{CH}_{3} \mathrm{COOH}$
$\mathrm{Br}^{-}+\mathrm{PAA} \rightarrow \mathrm{BrO}^{-}+\mathrm{CH}_{3} \mathrm{COOH}$.

By analogy with the oxygen-atom transfer reactions of $\mathrm{HSO}_{5}^{-}$and $\mathrm{HNO}_{4}$ with halide ions (Fortnum et al., 1960; Régimbal and Mozurkewich, 2000), PAA is also likely to oxidize $\mathrm{Cl}^{-}$at the rate two to three orders of magnitude slower than oxidizing $\mathrm{Br}^{-}$:

$\mathrm{Cl}^{-}+\mathrm{PAA} \rightarrow \mathrm{ClO}^{-}+\mathrm{CH}_{3} \mathrm{COOH}$.

In the present work, the rate constant of Reaction (59) is estimated by the rate constant ratio between the reactions of $\mathrm{Br}^{-}$and $\mathrm{Cl}^{-}$with $\mathrm{HSO}_{5}^{-}$taking $k_{58}$ as a reference (see Reaction (A186) in Table S8 in the electronic supplement).

Pandis and Seinfeld (1989), using a numerical model, demonstrated that Reaction (57) does not play a major role in cloudwater chemistry. However, Reactions (58)-(59) are potentially important for triggering autocatalytic halogen release (see Sect.5.6).

\section{Model description and experimental settings}

Numerical experiments in the present work are performed by the box model SEAMAC, which describes chemistry of $\mathrm{O}_{\mathrm{x}}$, $\mathrm{HO}_{\mathrm{x}}, \mathrm{NO}_{\mathrm{y}}, \mathrm{SO}_{\mathrm{x}}, \mathrm{Cl}_{\mathrm{x}}, \mathrm{Br}_{\mathrm{x}}$ species, hydrocarbons, and their oxidation products in the gas phase and in the deliquesced sea-salt aerosols occurring in the MBL of $1 \mathrm{~km}$ thickness (Toyota et al., 2001). SEAMAC owes its basic architecture to the ASAD atmospheric chemistry integration package (Carver et al., 1997), which allows flexible modifications of reaction scheme. As described in the previous section, the reaction scheme is updated to achieve a near-explicit description of degradation of up to $\mathrm{C}_{3}$-hydrocarbons. Consequently, the model includes 199 gas-phase species undergoing 645 reactions and 100 aqueous-phase species undergoing 279 reactions. Chemical interactions between the gas- and aerosolphases are treated as reversible mass transfer (43 species), irreversible uptake onto aerosols ( 1 species: $\mathrm{H}_{2} \mathrm{SO}_{4}$ ), or heterogeneous surface reactions on aerosols (10 species). Kinetic parameters have also been updated from those in our previous work (Toyota et al., 2001), where new experimental data are available (see the electronic supplement for a full account of reactions considered in the present work). Sizedependent aerosol processes are expressed by segregating the size distributions of sea-salt aerosols into 8 size bins according to their dry radius (from $0.06 \mu \mathrm{m}$ to $16 \mu \mathrm{m}$ ). For each bin, volumetric mean values are prescribed for liquid water content, atmospheric residence time, and mass transfer coefficients of chemical species, based on methods described in Toyota et al. (2001). The size distributions of dry sea-salt aerosols are taken from Porter and Clarke (1997), and linearly scaled to yield the total mass concentrations predicted by an empirical relationship between sea-salt mass loading and wind speed (Blanchard and Woodcock, 1980). In the present work model runs are conducted at the wind speed of $9 \mathrm{~m} / \mathrm{s}$, which yields $16.4 \mu \mathrm{g} / \mathrm{m}^{3}$ for the mass concentration of dry sea-salt aerosols. Actinic flux is calculated based on a two-stream algorithm in the pseudo-spherical atmosphere (Kylling, 1995; Kylling et al., 1995). It is assumed that the actinic flux inside aerosol particles is enhanced by a factor of two relative to that in the surrounding air as a result of multiple scattering within the particles (Ruggaber et al., 1997). Numerical integration is performed with the Livermore Solver for Ordinary Differential Equations with general Sparse jacobian matrix (LSODES) (Hindmarsh, 1983). Although actual time steps for integration are determined internally by LSODES depending on the stiffness of the ordinary differential equation system, the external time step is set to 120 seconds at which interval diurnally varying photolysis rates ( $\mathbf{J}$ values) are given.

The mid-latitude remote MBL condition is assumed for all model runs: $40^{\circ} \mathrm{N}$, Julian day 80 (equinox), $340 \mathrm{DU}$ total ozone, clear sky, and the sea surface albedo of 0.05 for calculating actinic flux; $1013.25 \mathrm{hPa}$ total pressure, $293 \mathrm{~K}$ temperature, and $76.2 \%$ relative humidity for calculating reaction rates and hygroscopic particle growth. $\mathrm{O}_{3}$ mixing ratio is fixed at $20 \mathrm{nmol} / \mathrm{mol}$ (Johnson et al., 1990; Oltmans and Levy, 1994). The mixing ratios of relatively long-lived VOCs are also fixed at values typical of the remote MBL:

$\left[\mathrm{CH}_{4}\right]=1.7 \mu \mathrm{mol} / \mathrm{mol}$,

$\left[\mathrm{C}_{2} \mathrm{H}_{6}\right]=400 \mathrm{pmol} / \mathrm{mol}$,

$\left[\mathrm{C}_{3} \mathrm{H}_{8}\right]=18 \mathrm{pmol} / \mathrm{mol}$,

$\left[\mathrm{C}_{2} \mathrm{H}_{2}\right]=35 \mathrm{pmol} / \mathrm{mol}$, and

$[\mathrm{CO}]=80 \mathrm{nmol} / \mathrm{mol}$ (Gregory et al., 1996);

$\left[\mathrm{CH}_{3} \mathrm{COCH}_{3}\right]=400 \mathrm{pmol} / \mathrm{mol}$ (Singh et al., 2001);

$\left[\mathrm{CHBr}_{3}\right]=1 \mathrm{pmol} / \mathrm{mol}$ (Penkett et al., 1985; Yokouchi et al., 1997).

For shorter-lived species such as alkenes, nitrogen oxides, and DMS, influxes from the ocean surface and/or from the free troposphere are invoked to maintain their calculated mixing ratios in the MBL (see Table 2). The oceanic emissions of $\mathrm{C}_{2} \mathrm{H}_{4}$ and $\mathrm{C}_{3} \mathrm{H}_{6}$ are taken from four independent works, which derived different values by more than an order of magnitude (Donahue and Prinn, 1990; Bonsang, 1993; Plass-Dülmer et al., 1993; Thompson et al., 1993). Oceanic $\mathrm{CH}_{3} \mathrm{CHO}$ emissions are estimated so as to give the observed mixing ratios in the remote MBL (Singh et al., 2001; Wisthaler et al., 2002). $\mathrm{NO}_{\mathrm{y}}$ is supplied into the model box in the form of $\mathrm{NO}, \mathrm{NO}_{2}, \mathrm{HNO}_{3}$, or PAN by entrainment from the free troposphere $\left(1.5 \times 10^{9}\right.$ molecule $\left.\mathrm{cm}^{-2} \mathrm{~s}^{-1}\right)$ and by emission from the ocean $\left(7 \times 10^{7}\right.$ molecule $\left.\mathrm{cm}^{-2} \mathrm{~s}^{-1}\right)$. A large fraction of $\mathrm{NO}, \mathrm{NO}_{2}$, and PAN will be converted 
Table 2. Influxes of chemical species that enter in the MBL from the free troposphere or from the ocean.

\begin{tabular}{|c|c|c|}
\hline Species & Influx $^{a}$ & Reference \\
\hline \multicolumn{3}{|c|}{ Entrainment from the Free Troposphere } \\
\hline $\mathrm{NO}_{\mathrm{y}}$ & $1.5 \times 10^{9}$ & Estimated $^{b, c}$ \\
\hline \multicolumn{3}{|c|}{ Emissions from the Ocean } \\
\hline DMS & $2 \times 10^{9}$ & Quinn et al. (1990) \\
\hline NO & $7 \times 10^{7}$ & Zafiriou and McFarland (1981) \\
\hline \multirow[t]{4}{*}{$\mathrm{C}_{2} \mathrm{H}_{4}$} & $2.4 \times 10^{8}$ & Plass-Dülmer et al. (1993) \\
\hline & $6.15 \times 10^{8}$ & Thompson et al. (1993) \\
\hline & $1.8 \times 10^{9}$ & Bonsang (1993), base case \\
\hline & $5.4 \times 10^{9}$ & Donahue and Prinn (1990) \\
\hline \multirow[t]{4}{*}{$\mathrm{C}_{3} \mathrm{H}_{6}$} & $9.8 \times 10^{7}$ & Plass-Dülmer et al. (1993) \\
\hline & $4.45 \times 10^{8}$ & Thompson et al. (1993) \\
\hline & $1.0 \times 10^{9}$ & Bonsang (1993), base case \\
\hline & $8.8 \times 10^{9}$ & Donahue and Prinn (1990) \\
\hline \multirow[t]{2}{*}{$\mathrm{CH}_{3} \mathrm{CHO}$} & $3.6 \times 10^{9}$ & Estimated, base case $\mathrm{e}^{d}$ \\
\hline & $8 \times 10^{9}$ & Estimated, higher case $^{d}$ \\
\hline
\end{tabular}

Notes:

${ }^{a}$ Unit: molecule $\mathrm{cm}^{-2} \mathrm{~s}^{-1}$;

${ }^{b}$ Estimated to yield about $10-20 \mathrm{pmol} / \mathrm{mol}$ of $\mathrm{NO}_{\mathrm{x}}$ (Gregory et al., 1996; Heikes et al., 1996), where $\mathrm{NO}_{\mathrm{y}}$ flux from the free troposphere is assumed to comprise $20 \% \mathrm{NO}_{\mathrm{x}}, 30 \% \mathrm{PAN}$, and $50 \%$ $\mathrm{HNO}_{3}$ (Kondo et al., 1997);

${ }^{c}$ A sensitivity study is also performed in which $\mathrm{NO}_{\mathrm{y}}$ flux is changed between $5 \times 10^{8}$ and $1 \times 10^{10}$ molecule $\mathrm{cm}^{-2} \mathrm{~s}^{-1}$ (see Sect. 5.4);

${ }^{d}$ Estimated to yield $\mathrm{CH}_{3} \mathrm{CHO}$ mixing ratios of about $90 \mathrm{pmol} / \mathrm{mol}$ (base case; Singh et al., 2001) or about $200 \mathrm{pmol} / \mathrm{mol}$ (higher case; Wisthaler et al., 2002)

to $\mathrm{HNO}_{3}$ or $\mathrm{BrONO}_{2}$ via photochemical processes in the MBL, thereby serving as a source of $\mathrm{NO}_{3}^{-}$in the seasalt aerosols along with $\mathrm{HNO}_{3}$ entrained from the free troposphere. Similarly, DMS emitted from the ocean $\left(2 \times 10^{9}\right.$ molecule $\left.\mathrm{cm}^{-2} \mathrm{~s}^{-1}\right)$ will be oxidized to give $\mathrm{SO}_{4}^{2-}$ or $\mathrm{CH}_{3} \mathrm{SO}_{3}^{-}$. In our model runs $\mathrm{NO}_{3}^{-}, \mathrm{SO}_{4}^{2-}$, and $\mathrm{CH}_{3} \mathrm{SO}_{3}^{-}$ thus produced are the principal sources of acidity in sea-salt aerosols (see Figs. 2b-d). Among the species emitted from the ocean, $\mathrm{NO}, \mathrm{C}_{2} \mathrm{H}_{4}, \mathrm{C}_{3} \mathrm{H}_{6}$, and $\mathrm{CH}_{3} \mathrm{CHO}$ are primarily produced via photochemical processes in seawater (Zafiriou and McFarland, 1981; Ratte et al., 1993, 1998; Zhou and Mopper, 1997) and hence their emission rates are scaled by diurnally varying $\mathrm{J}\left(\mathrm{NO}_{2}\right)$ values.

Organic oxygenates, whether halogenated or not, will be subject to dry and/or wet deposition. In the present work, dry deposition velocities for organic oxygenates are given as follows: $0.1 \mathrm{~cm} / \mathrm{sec}$ for ketones and alcohols, $0.5 \mathrm{~cm} / \mathrm{sec}$ for peroxy radicals, hydroperoxides, aldehydes except for $\mathrm{CH}_{3} \mathrm{CHO}$, and carbonyl halides (e.g. $\mathrm{HCOBr}$ ), and $1 \mathrm{~cm} / \mathrm{sec}$ for carboxylic acids. The dry deposition velocities $\left(v_{0}\right)$ are then converted to first-order loss rate coefficients $(D)$ in the model box following an approach taken by Levy et al. (1985):

$$
D=\frac{v_{0}}{Z_{\mathrm{mbl}}} \frac{1}{1+v_{0} / C_{\mathrm{M}} U_{\mathrm{s}}}
$$

where $Z_{\mathrm{mbl}}$ is the MBL thickness $(=1 \mathrm{~km}), C_{\mathrm{M}}$ is bulk coefficient for mass transfer over the ocean $(=0.0011$; Garratt, $1992)$, and $U_{\mathrm{s}}$ is wind speed over the ocean $(=9 \mathrm{~m} / \mathrm{s})$. The wet deposition is assumed to take place for carboxylic acids, aldehydes, and carbonyl halides as a first-order loss process with $\tau=8$ day.

\section{Results and Discussion}

In the present work the impacts of acetaldehyde, alkenes, and acetylene on bromine activation are assessed by varying their oceanic emission rates or their mixing ratios in the MBL (see Table 3). In each run numerical integration is carried out for 20 days long, starting at 0:00 a.m. local sun time. Initially, halogen species are present only in the forms of $\mathrm{Br}^{-}(\sim 9.8 \mathrm{pmol} / \mathrm{mol})$ and $\mathrm{Cl}^{-}(\sim 6.4 \mathrm{nmol} / \mathrm{mol})$ within nascent sea-salt aerosols, $\mathrm{HCl}(60 \mathrm{pmol} / \mathrm{mol})$ and $\mathrm{CHBr}_{3}$ $(1 \mathrm{pmol} / \mathrm{mol})$ in the gas phase. Uptake of sulfur and nitrogen oxides from the gas phase initiates radical chain reactions in the deliquesced sea-salt aerosols, which consequently release a small amount of $\mathrm{Br}_{2}$ to the gas phase. At the same time sea-salt aerosols other than those belonging to the largestsize bin are acidified and buffered to $\mathrm{pH}$ of about $4-5$ by releasing (or taking up) $\mathrm{HCl}$ to (or from) the gas phase (see Figs. 2a-f). Under sunlight Reactions (1)-(10) also operate to release $\mathrm{Br}_{2}$ and $\mathrm{BrCl}$ from the acidified sea-salt aerosols and thus the amounts of reactive halogen species increase significantly with time (see Figs. 3a-f). Within 10 days or so, the temporal evolutions of $\mathrm{pH}$ and $\mathrm{Cl}^{-}$deficits in the seasalt aerosols other than those belonging to smallest-size bins are getting stabilized and the buildup of reactive halogens is limited by the decreased availability of $\mathrm{Br}^{-}$in the seasalt aerosols. However, $\mathrm{pH}$ and $\mathrm{Cl}^{-}$deficits in the sea-salt aerosols of smallest-size bins evolve slowly with time in accordance with the accumulation of sulfate until Day 20. This causes the gradual buildup of reactive halogens lasting until Day 20.

In Runs 1a-e and 2-5, the oceanic emission rate(s) of either $\mathrm{CH}_{3} \mathrm{CHO}$ or alkenes are varied to examine their impacts on reactive halogen chemistry. Here the mixing ratios of $\mathrm{HCHO}, \mathrm{CH}_{3} \mathrm{CHO}, \mathrm{C}_{2} \mathrm{H}_{4}$, and $\mathrm{C}_{3} \mathrm{H}_{6}$ are calculated according to their oceanic emissions, photochemical sources/sinks, and dry/wet deposition to the sea surface with the initial mixing ratios given as $\left[\mathrm{C}_{2} \mathrm{H}_{4}\right]=\left[\mathrm{C}_{3} \mathrm{H}_{6}\right]=0 \mathrm{pmol} / \mathrm{mol}$, $\left[\mathrm{CH}_{3} \mathrm{CHO}\right]=90 \mathrm{pmol} / \mathrm{mol}$, and $[\mathrm{HCHO}]=300 \mathrm{pmol} / \mathrm{mol}$ in each run. Their mixing ratios generally reach quasi-steady states on shorter time scales than those of reactive halogens (not shown). Thus the quasi-steady-state levels of reactive halogens after Day 10 and their transient behaviors before that are persistently affected by the "adjusted" mixing ratios 
Dry Radius $(\mu \mathrm{m})$
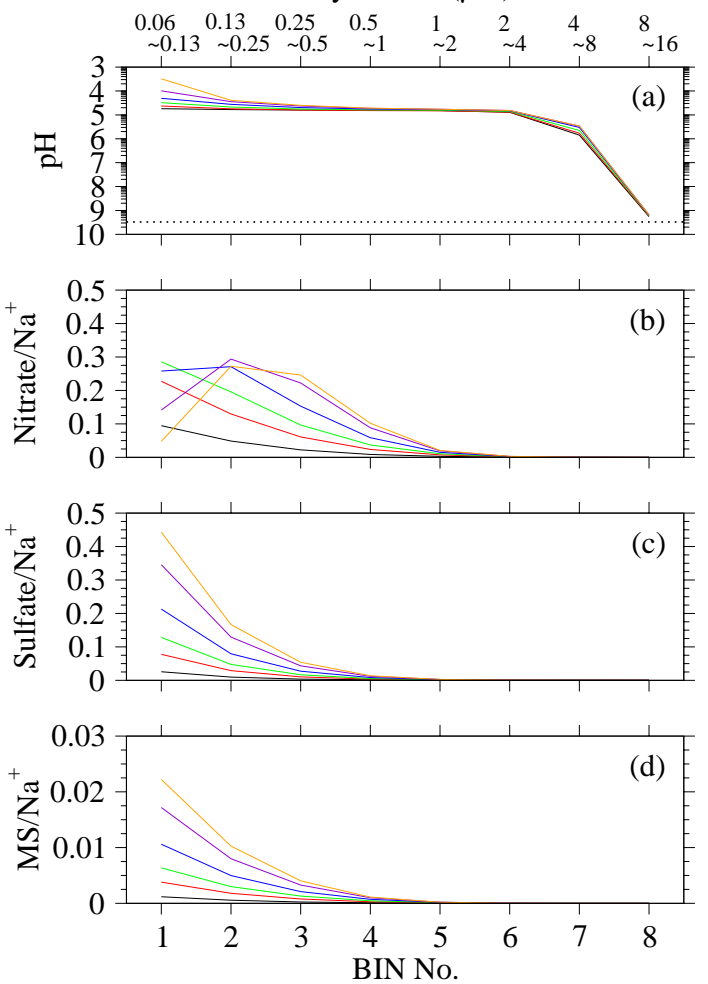

Dry Radius $(\mu \mathrm{m})$
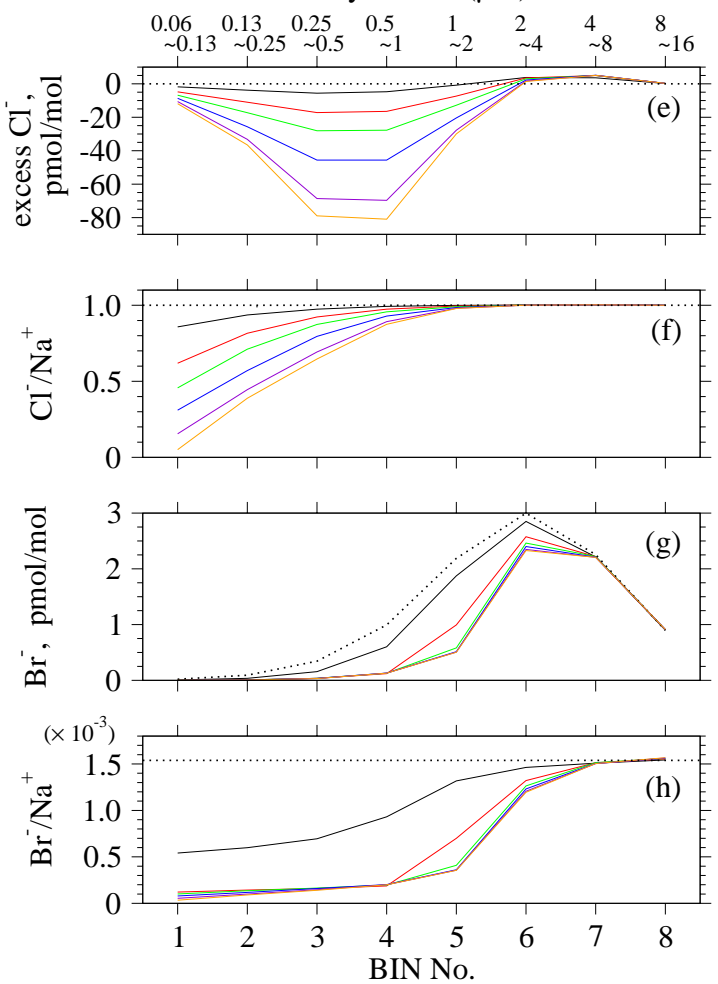

Fig. 2. Simulated temporal evolutions of $\mathrm{pH}(\mathbf{a}),\left(\mathrm{HNO}_{3}+\mathrm{NO}_{3}^{-}\right) / \mathrm{Na}^{+}$molar ratio (b), $\left(\mathrm{HSO}_{4}^{-}+\mathrm{SO}_{4}^{2-}\right) / \mathrm{Na}^{+}$molar ratio $(\mathbf{c})$,

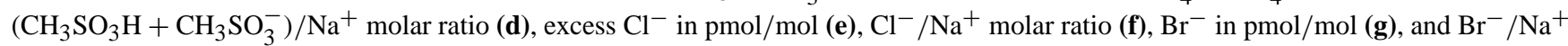
molar ratio (h) as a function of particle size of the sea-salt aerosols for Run 1a. Daily averaged values on Days 1 (black lines), 2 (red lines), 3 (green lines), 5 (blue lines), 10 (violet lines), 20 (orange lines) are presented. Dotted lines correspond to values in nascent sea-salt aerosols.
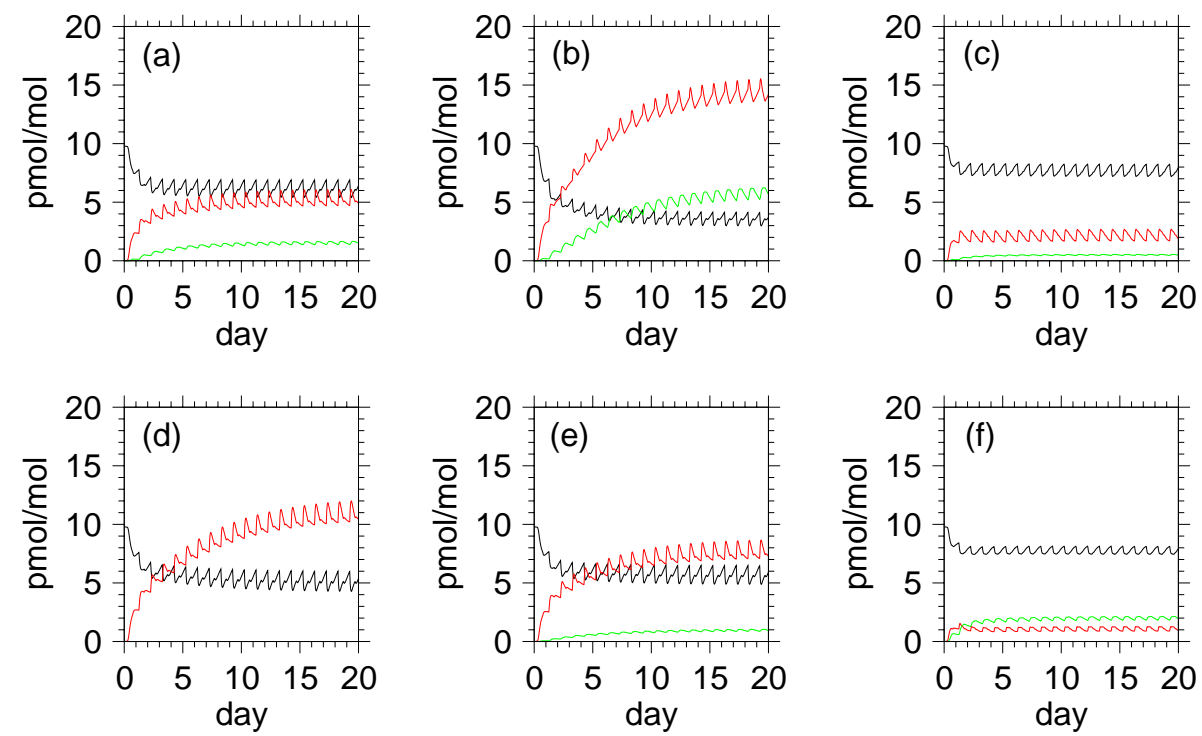

Fig. 3. Impacts of the oceanic emissions of acetaldehyde and alkenes on the simulated mixing ratios of bromine species: (a) Run 1a, (b) Run 1b, (c) Run 1c, (d) Run 2, (e) Run 4, and (f) Run 5. Black lines represent the total mixing ratios of $\mathrm{Br}^{-}$in sea-salt aerosols, red lines the total mixing ratios of inorganic gaseous bromine species, and green lines the total mixing ratios of organic gaseous bromine species formed via $\mathrm{Br}$-initiated degradation of $\mathrm{C}_{2} \mathrm{H}_{4}, \mathrm{C}_{3} \mathrm{H}_{6}$, and $\mathrm{C}_{2} \mathrm{H}_{2}$. 
Table 3. Overview of model runs.

\begin{tabular}{|c|c|}
\hline No. & Brief Description \\
\hline 1a & Base run; alkene emission rates taken from Bonsang (1993) \\
\hline $1 \mathrm{~b}$ & The same as Run 1a but without the oceanic emission of $\mathrm{CH}_{3} \mathrm{CHO}$ \\
\hline $1 \mathrm{c}$ & The same as Run 1a but with the higher emission rate of $\mathrm{CH}_{3} \mathrm{CHO}$ from the ocean \\
\hline $1 d$ & The same as Run 1a but without the oceanic emission of $\mathrm{C}_{2} \mathrm{H}_{4}$ \\
\hline $1 \mathrm{e}$ & The same as Run 1a but without the oceanic emission of $\mathrm{C}_{3} \mathrm{H}_{6}$ \\
\hline 1f & The same as Run 1a but with absorption cross sections for brominated hydroperoxides red-shifted by $50 \mathrm{~nm}$ \\
\hline $1 \mathrm{~g}$ & The same as Run 1a but with reduced $\gamma$ values $\left(=8 \times 10^{-4}\right)$ for hydrolysis of $\mathrm{HCOBr} / \mathrm{HCOCl}$ on aerosols \\
\hline $1 \mathrm{~h}$ & The same as Run 1a but with specifying $\left[\mathrm{C}_{2} \mathrm{H}_{2}\right]=200 \mathrm{pmol} / \mathrm{mol}\left(\mathrm{cf} .\left[\mathrm{C}_{2} \mathrm{H}_{2}\right]=35 \mathrm{pmol} / \mathrm{mol}\right.$ in Run 1a) \\
\hline 1i & The same as Run $1 \mathrm{~g}$ but with specifying $\left[\mathrm{C}_{2} \mathrm{H}_{2}\right]=200 \mathrm{pmol} / \mathrm{mol}\left(\mathrm{cf} .\left[\mathrm{C}_{2} \mathrm{H}_{2}\right]=35 \mathrm{pmol} / \mathrm{mol}\right.$ in Run $\left.1 \mathrm{~g}\right)$ \\
\hline $1 \mathrm{j}$ & $\begin{array}{l}\text { The same as Run 1a but with halogen chemistry switched off by taking off the atmospheric loading of sea-salt aerosols and by } \\
\text { specifying }\left[\mathrm{CHBr}_{3}\right]=0 \mathrm{pmol} / \mathrm{mol}\end{array}$ \\
\hline 2 & No alkene emissions from the ocean \\
\hline 3 & Alkene emission rates taken from Plass-Dülmer et al. (1993) \\
\hline 4 & Alkene emission rates taken from Thompson et al. (1993) \\
\hline 5 & Alkene emission rates taken from Donahue and Prinn (1990) \\
\hline $6 \mathrm{a}$ & $\begin{array}{l}\text { Similar to Run } 2 \text { but with the mixing ratios of } \mathrm{C}_{2} \mathrm{H}_{4}, \mathrm{C}_{3} \mathrm{H}_{6}, \mathrm{HCHO} \text {, and } \mathrm{CH}_{3} \mathrm{CHO} \text { fixed at } 0.0,0.0,265.6 \text {, and } 80.2 \mathrm{pmol} / \mathrm{mol} \text {, } \\
\text { respectively }\end{array}$ \\
\hline $6 \mathrm{~b}$ & $\begin{array}{l}\text { Similar to Run 1a but with the mixing ratios of } \mathrm{C}_{2} \mathrm{H}_{4}, \mathrm{C}_{3} \mathrm{H}_{6}, \mathrm{HCHO} \text {, and } \mathrm{CH}_{3} \mathrm{CHO} \text { fixed at 89.9, 12.6, 301.2, and } 94.7 \mathrm{pmol} / \mathrm{mol} \text {, } \\
\text { respectively }\end{array}$ \\
\hline $6 \mathrm{c}$ & The same as Run 6a but with the mixing ratios of $\mathrm{HCHO}$ and $\mathrm{CH}_{3} \mathrm{CHO}$ fixed at 301.2 and $94.7 \mathrm{pmol} / \mathrm{mol}$, respectively \\
\hline $6 \mathrm{~d}$ & The same as Run $6 \mathrm{~b}$ but with the mixing ratios of $\mathrm{HCHO}$ and $\mathrm{CH}_{3} \mathrm{CHO}$ fixed at 265.6 and $80.2 \mathrm{pmol} / \mathrm{mol}$, respectively \\
\hline $7 \mathrm{a}$ & $\begin{array}{l}\text { Parameter sweep experiment; multiple model runs are performed in which different mixing ratios of } \mathrm{CH}_{3} \mathrm{CHO} \text { are specified } \\
\text { ranging from } 0 \text { to } 250 \mathrm{pmol} / \mathrm{mol} \text { with those of } \mathrm{HCHO}, \mathrm{C}_{2} \mathrm{H}_{4} \text {, and } \mathrm{C}_{3} \mathrm{H}_{6} \text { fixed at } 300,30 \text {, and } 15 \mathrm{pmol} / \mathrm{mol} \text {, respectively }\end{array}$ \\
\hline $7 b$ & $\begin{array}{l}\text { Parameter sweep experiment; multiple model runs are performed in which different mixing ratios of } \mathrm{C}_{2} \mathrm{H}_{4} \text { are specified ranging } \\
\text { from } 0 \text { to } 100 \mathrm{pmol} / \mathrm{mol} \text { with those of } \mathrm{HCHO}, \mathrm{CH}_{3} \mathrm{CHO} \text {, and } \mathrm{C}_{3} \mathrm{H}_{6} \text { fixed at } 300,90 \text {, and } 15 \mathrm{pmol} / \mathrm{mol} \text {, respectively }\end{array}$ \\
\hline $7 \mathrm{c}$ & $\begin{array}{l}\text { Parameter sweep experiment; multiple model runs are performed in which different mixing ratios of } \mathrm{C}_{3} \mathrm{H}_{6} \text { are specified ranging } \\
\text { from } 0 \text { to } 30 \mathrm{pmol} / \mathrm{mol} \text { with those of } \mathrm{HCHO}, \mathrm{CH}_{3} \mathrm{CHO} \text {, and } \mathrm{C}_{2} \mathrm{H}_{4} \text { fixed at } 300,90 \text {, and } 30 \mathrm{pmol} / \mathrm{mol} \text {, respectively }\end{array}$ \\
\hline $7 \mathrm{~d}$ & $\begin{array}{l}\text { Parameter sweep experiment; multiple model runs are performed in which different } \mathrm{NO}_{\mathrm{y}} \text { fluxes from the free troposphere are } \\
\text { given ranging from } 5 \times 10^{8} \text { to } 1 \times 10^{10} \text { molecule } \mathrm{cm}^{-2} \mathrm{~s}^{-1} \text { with the mixing ratios of } \mathrm{HCHO}, \mathrm{CH}_{3} \mathrm{CHO}, \mathrm{C}_{2} \mathrm{H}_{4}, \text { and } \mathrm{C}_{3} \mathrm{H}_{6} \text { fixed at } \\
300,90,30 \text {, and } 15 \mathrm{pmol} / \mathrm{mol} \text {, respectively }\end{array}$ \\
\hline
\end{tabular}

of these alkenes and aldehydes. Before proceeding to discussion about their influence on halogen chemistry, we will describe how the simulated mixing ratios of alkenes and aldehydes are related to their oceanic emissions.

5.1 Impacts of oceanic emissions on the mixing ratios of $\mathrm{C}_{2} \mathrm{H}_{4}, \mathrm{C}_{3} \mathrm{H}_{6}, \mathrm{CH}_{3} \mathrm{CHO}$, and $\mathrm{HCHO}$

First of all, it should be noted that halogen chemistry plays a minor role in the photochemical loss of $\mathrm{C}_{2} \mathrm{H}_{4}, \mathrm{C}_{3} \mathrm{H}_{6}, \mathrm{HCHO}$, and $\mathrm{CH}_{3} \mathrm{CHO}$ in the MBL. Breakdowns of their photochemical loss processes in Run 1a (base run) are as follows: for $\mathrm{C}_{2} \mathrm{H}_{4} 90 \%$ by $\mathrm{OH}$ attack, $9 \%$ by reaction with $\mathrm{O}_{3}$, and the remaining $1 \%$ by reactions with halogen atoms (mainly $\mathrm{Cl}$ atoms); for $\mathrm{C}_{3} \mathrm{H}_{6} 83 \%$ by $\mathrm{OH}$ attack, $14 \%$ by reaction with $\mathrm{O}_{3}$, and the remaining $3 \%$ by reactions with halogen atoms (mainly $\mathrm{Br}$ atoms); for $\mathrm{HCHO} 64 \%$ by photolysis, $35 \%$ by $\mathrm{OH}$ attack, and $1 \%$ by reactions with halogen atoms (mainly $\mathrm{Br}$ atoms); for $\mathrm{CH}_{3} \mathrm{CHO} 90 \%$ by $\mathrm{OH}$ attack, $5 \%$ by photolysis, and $5 \%$ by reactions with halogen atoms (mostly $\mathrm{Br}$ atoms). $\mathrm{NO}_{3}$ attacks in the gas phase and aqueous-phase reactions in deliquesced sea-salt aerosols make negligible contributions to the loss of $\mathrm{HCHO}$ and $\mathrm{CH}_{3} \mathrm{CHO}$. Thus, the changing level of activity in halogen chemistry among model runs is not a critical factor for determining the mixing ratios of these alkenes and aldehydes.

The oceanic emissions of alkenes and their resultant buildup in the MBL, if they are large enough, can appreciably augment the photochemical loss rate of $\mathrm{OH}$ radicals (Donahue and Prinn, 1990). In our model runs, however, the simulated concentrations of $\mathrm{OH}$ radical, which is the most important scavenger of alkenes, change by not more than $25 \%$ following more than an order of magnitude change in oceanic alkene fluxes (see Table 4). In addition, the mixing ratio of $\mathrm{O}_{3}$, which is the second most important scavenger of alkenes, is fixed at the same value $(20 \mathrm{nmol} / \mathrm{mol})$ in all model runs. Thus, the simulated mixing ratios of alkenes are virtually linearly related to their oceanic emission rates. Among the model runs conducted, Runs 1a and 4 yield the mixing ratios of $\mathrm{C}_{2} \mathrm{H}_{4}$ (ca. 30-90 pmol/mol) and $\mathrm{C}_{3} \mathrm{H}_{6}$ (ca. 
Table 4. Mixing ratios of $\mathrm{C}_{2} \mathrm{H}_{4}, \mathrm{C}_{3} \mathrm{H}_{6}, \mathrm{HCHO}, \mathrm{CH}_{3} \mathrm{CHO}, \mathrm{CH}_{3} \mathrm{OOH}, \mathrm{CH}_{3} \mathrm{C}(\mathrm{O}) \mathrm{OOH}(\mathrm{PAA})$, total inorganic gaseous bromine (i-Br $\mathrm{x}_{\mathrm{x}}$ ), total brominated organic intermediates in the gas phase formed via Br-initiated degradation of $\mathrm{C}_{2} \mathrm{H}_{4}, \mathrm{C}_{3} \mathrm{H}_{6}$, and $\mathrm{C}_{2} \mathrm{H}_{2}\left(\mathrm{o}-\mathrm{Br}_{\mathrm{x}}\right), \mathrm{NO}_{\mathrm{x}}$, and $\mathrm{DMS}$, $\mathrm{OH}$ concentrations, $\mathrm{Br}^{-}$loss from sea-salt aerosols, and net chemical production rates of $\mathrm{O}_{3}\left(\mathrm{P}-\mathrm{L}\left(\mathrm{O}_{3}\right)\right)$ as simulated in Runs 1a-j and 2-5. Daily averaged values on Day 20 are presented.

\begin{tabular}{|c|c|c|c|c|c|c|c|c|c|c|c|c|c|c|}
\hline & $1 \mathrm{a}$ & $1 b$ & $1 \mathrm{c}$ & $1 d$ & 1e & $1 \mathrm{f}$ & $1 \mathrm{~g}$ & $1 \mathrm{~h}$ & $1 \mathrm{i}$ & $1 j$ & 2 & 3 & 4 & 5 \\
\hline $\mathrm{C}_{2} \mathrm{H}_{4}{ }^{a}$ & 89.9 & 83.0 & 95.0 & $0.0069^{d}$ & 88.2 & 90.0 & 89.9 & 90.0 & 89.9 & 88.3 & 0.0 & 11.5 & 29.9 & 329.2 \\
\hline $\mathrm{C}_{3} \mathrm{H}_{6}{ }^{a}$ & 12.6 & 11.3 & 13.4 & 12.3 & 0.0 & 12.6 & 12.6 & 12.6 & 12.6 & 12.6 & 0.0 & 1.2 & 5.4 & 134.3 \\
\hline $\mathrm{HCHO}^{a}$ & 301.2 & 260.8 & 331.2 & 283.4 & 285.6 & 298.8 & 302.0 & 301.1 & 302.0 & 322.5 & 265.6 & 270.3 & 280.8 & 406.7 \\
\hline $\mathrm{CH}_{3} \mathrm{CHO}^{a}$ & 94.7 & 11.6 & 209.9 & 91.8 & 83.7 & 94.2 & 94.8 & 94.8 & 94.9 & 97.0 & 80.2 & 81.9 & 86.6 & 202.0 \\
\hline $\mathrm{CH}_{3} \mathrm{OOH}^{a}$ & 793.3 & 824.8 & 800.8 & 821.9 & 814.9 & 798.9 & 791.5 & 793.4 & 791.4 & 747.2 & 850.7 & 842.4 & 824.6 & 733.3 \\
\hline $\mathrm{PAA}^{a}$ & 79.8 & 26.9 & 140.1 & 79.8 & 70.8 & 80.4 & 79.7 & 80.0 & 79.8 & 75.7 & 71.2 & 71.9 & 74.9 & 156.5 \\
\hline $\mathrm{Br}^{-}$loss & $37.5 \%$ & $63.9 \%$ & $21.6 \%$ & $40.2 \%$ & $43.0 \%$ & $38.4 \%$ & $37.3 \%$ & $37.2 \%$ & $37.1 \%$ & - & $48.1 \%$ & $46.3 \%$ & $42.5 \%$ & $21.0 \%$ \\
\hline $\mathrm{i}-\mathrm{Br}_{\mathrm{X}}{ }^{a}$ & 5.2 & 14.4 & 2.2 & 6.4 & 8.1 & 5.95 & 5.0 & 5.15 & 4.9 & 0.0 & 10.85 & 9.8 & 7.7 & 1.1 \\
\hline $\mathrm{o}-\mathrm{Br}_{\mathrm{X}}{ }^{a}$ & 1.5 & 5.8 & 0.5 & 1.4 & 0.7 & 1.1 & 1.6 & 1.5 & 1.6 & 0.0 & $0.00068^{e}$ & 0.3 & 1.0 & 2.0 \\
\hline $\mathrm{OH}^{b}$ & 9.04 & 9.49 & 8.60 & 9.27 & 9.16 & 9.02 & 9.05 & 9.04 & 9.05 & 9.37 & 9.40 & 9.35 & 9.26 & 7.34 \\
\hline $\mathrm{NO}_{\mathrm{X}}{ }^{a}$ & 19.5 & 11.5 & 23.4 & 18.2 & 16.8 & 18.8 & 19.7 & 19.5 & 19.8 & 25.1 & 14.7 & 15.4 & 17.1 & 25.6 \\
\hline $\mathrm{DMS}^{a}$ & 74.5 & 44.6 & 90.7 & 69.2 & 64.7 & 72.3 & 75.3 & 74.9 & 75.7 & 93.0 & 56.5 & 59.2 & 65.5 & 108.4 \\
\hline $\mathrm{P}-\mathrm{L}\left(\mathrm{O}_{3}\right)^{c}$ & -1.09 & -1.79 & -0.86 & -1.18 & -1.28 & -1.14 & -1.08 & -1.09 & -1.07 & -0.71 & -1.46 & -1.39 & -1.26 & -0.79 \\
\hline
\end{tabular}

Notes:

${ }^{a}$ Unit: $\mathrm{pmol} / \mathrm{mol}$;

${ }^{b}$ Unit: $10^{5}$ molecule $/ \mathrm{cm}^{3}$;

${ }^{c}$ Unit: nmol/mol/day, a negative value implies net chemical loss;

${ }^{d}$ Formed via photolysis of acrolein $\left(\mathrm{CH}_{2}=\mathrm{CHCHO}\right)$, which is a minor product of $\mathrm{C}_{3} \mathrm{H}_{6}$ degradation;

${ }^{e} \mathrm{HCOBr}$ formed via the reaction $\mathrm{Br}+\mathrm{C}_{2} \mathrm{H}_{2}$

5-13 pmol/mol) in fair agreement with those observed in the MBL (see Table 1). At these concentration levels $\mathrm{C}_{3} \mathrm{H}_{6}$ exerts a much stronger influence on halogen chemistry than $\mathrm{C}_{2} \mathrm{H}_{4}$ does (see Sects. 5.3-5.4). From this standpoint Run 1a is regarded as a base run in the present work, because it obtains the $\mathrm{C}_{3} \mathrm{H}_{6}$ mixing ratio in the middle of the typically observed range. The mixing ratios of $\mathrm{C}_{2} \mathrm{H}_{4}$ and $\mathrm{C}_{3} \mathrm{H}_{6}$ in Run 3 are about $10 \mathrm{pmol} / \mathrm{mol}$ and $1 \mathrm{pmol} / \mathrm{mol}$, respectively, which are near the lower ends of the observed ranges. Although the mixing ratios of $\mathrm{C}_{2} \mathrm{H}_{4}$ (ca. $330 \mathrm{pmol} / \mathrm{mol}$ ) and $\mathrm{C}_{3} \mathrm{H}_{6}$ (ca. $130 \mathrm{pmol} / \mathrm{mol}$ ) in Run 5 are well above those typically observed in the MBL remote from continental influences, their impacts on bromine chemistry are noteworthy as will be shown in Sect. 5.3. Since alkenes higher than $\mathrm{C}_{3} \mathrm{H}_{6}$ (isoprene in particular) are also emitted from the ocean (Donahue and Prinn, 1993; Pszenny et al., 1999; Yokouchi et al., 1999; Baker et al., 2000) and then react quite rapidly with $\mathrm{Br}$ atoms (Bierbach et al., 1996), Run 5 can be regarded as mimicking a potentially feasible situation in which such higher alkenes play important roles.

In the case of aldehydes, relationships between oceanic emissions and simulated mixing ratios are relatively complicated due to their secondary formation in the air. Where the oceanic $\mathrm{CH}_{3} \mathrm{CHO}$ emission is set to $3.6 \times 10^{9}$ molecule $\mathrm{cm}^{-2} \mathrm{~s}^{-1}$ (Run 1a), the simulated $\mathrm{CH}_{3} \mathrm{CHO}$ mixing ratio is about $95 \mathrm{pmol} / \mathrm{mol}$. This mixing ratio agrees quite well with those observed by Singh et al. (2001) in the tropical/subtropical Pacific MBL (see Table 1). Where the oceanic $\mathrm{CH}_{3} \mathrm{CHO}$ emission is switched off (Run 1b), the $\mathrm{CH}_{3} \mathrm{CHO}$ mixing ratio decreases to as low as about $10 \mathrm{pmol} / \mathrm{mol}$, to which the oxidations of $\mathrm{C}_{2} \mathrm{H}_{6}$ and $\mathrm{C}_{3} \mathrm{H}_{6}$ equally contribute as a source. This implies that a significant fraction of $\mathrm{CH}_{3} \mathrm{CHO}$ originates from its oceanic emission in the remote MBL. Accordingly, the oceanic $\mathrm{CH}_{3} \mathrm{CHO}$ emission 2.2 times greater than that in Run 1a, i.e. $8 \times 10^{9}$ molecule $\mathrm{cm}^{-2} \mathrm{~s}^{-1}$, is sufficient to reproduce more than twice as high as $\mathrm{CH}_{3} \mathrm{CHO}$ mixing ratio such as those observed by Wisthaler et al. (2002) in the equatorial Indian Ocean (Run 1c; see Tables 1 and 4). It is interesting to note that $\mathrm{C}_{3} \mathrm{H}_{6}$, if present as abundant as in Run 5, can also provide a dominant source of $\mathrm{CH}_{3} \mathrm{CHO}$.

The range of $\mathrm{HCHO}$ mixing ratios simulated in our model runs (261-407 pmol/mol; see Table 4) agrees fairly well with those observed at Cape Grim (ca. 250-450 pmol/mol; Ayers et al., 1997), in the tropical Atlantic MBL south of ITCZ (ca. 300-700 pmol/mol; Junkermann and Stockwell, 1999), and in the tropical Pacific MBL (ca. $300 \mathrm{pmol} / \mathrm{mol}$; Singh et al., 2001). Although the oxidation of $\mathrm{CH}_{4}$ is a dominant source of HCHO in our model runs, the simulated HCHO mixing ratios depend on the oceanic emissions of alkenes to some extent. In addition to the photochemical production of $\mathrm{HCHO}$ via alkene degradation in the air, alkenes exert an indirect influence on the simulated $\mathrm{HCHO}$ mixing ratio by changing $\mathrm{NO}_{\mathrm{x}}$ mixing ratios via bromine chemistry. As will 


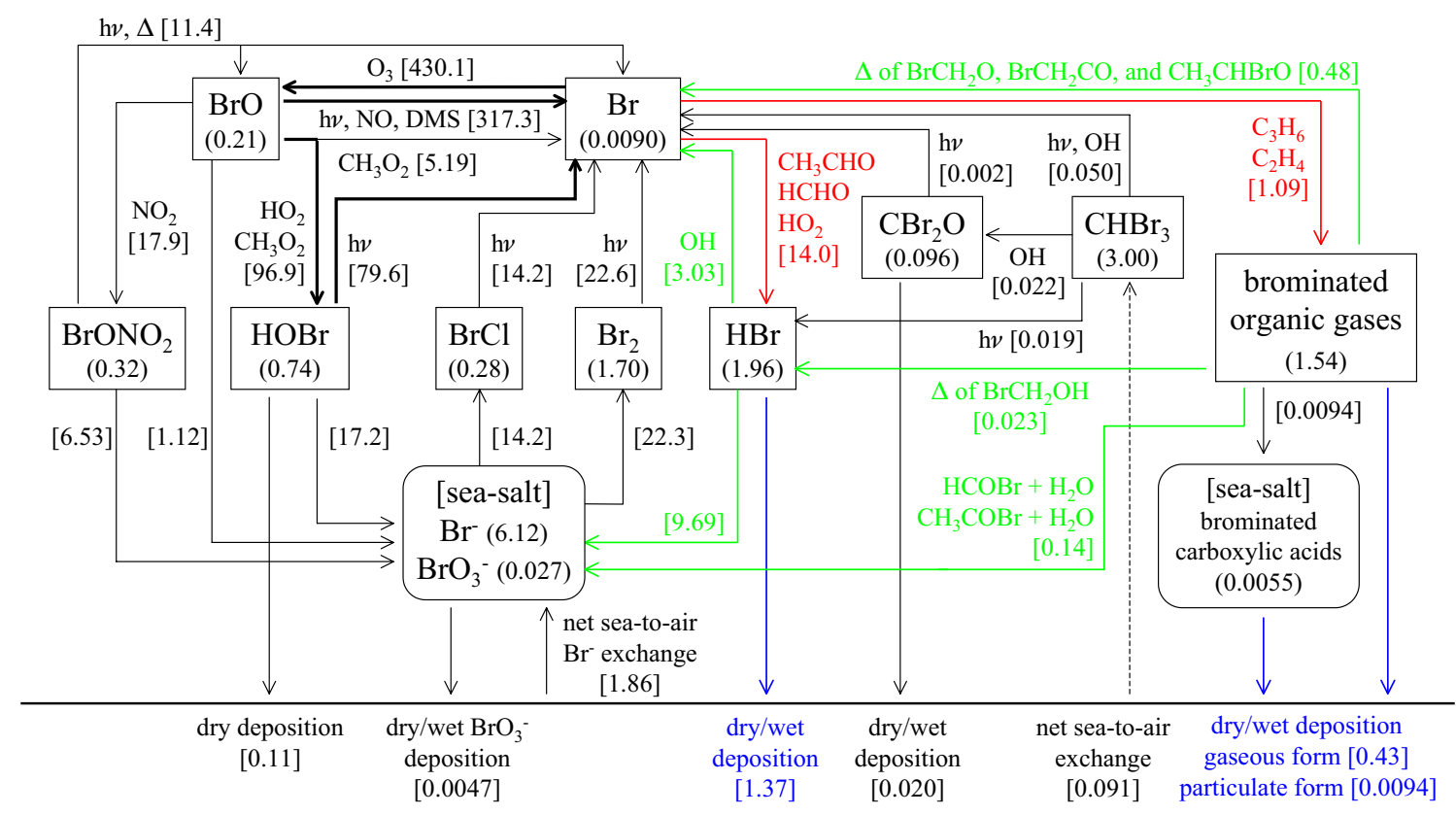

Fig. 4. The material cycle of bromine species as simulated on Day 20 in Run 1a. The numbers in parentheses are daily average mixing ratios in $\mathrm{pmol}(\mathrm{Br}) / \mathrm{mol}$ and those in brackets the rates of either chemical transformation or air-sea mass exchange in $\mathrm{pmol}(\mathrm{Br}) / \mathrm{mol} / \mathrm{day}$. " $\Delta$ " represents decomposition via either thermal unimolecular reaction or fragmentation of an excited molecule. Where two or more reactions contribute to the same transformation pathway, only those contributing by more than $2 \%$ of the total are listed in order of their relative importance. Small imbalance in mass flow rates apparent for $\mathrm{Br}_{2}$ is caused by neglecting a contribution from $\mathrm{Br}_{2}$ formation via self-reaction of BrO. The net sea-to-air exchange rate of $\mathrm{CHBr}_{3}$ is calculated so as to balance with its photochemical loss in the air, since the mixing ratio of this compound is specified rather than simulated in the model.

be shown in Sect. 5.3, bromine chemistry becomes less active with increasing alkene mixing ratios, leading to a less efficient oxidation of $\mathrm{NO}_{2}$ via Reaction (10) followed by the aerosol uptake of $\mathrm{BrONO}_{2}$ (Sander et al., 1999; Toyota et al., 2001). With increasing $\mathrm{NO}_{\mathrm{x}}$ mixing ratio, the yield of $\mathrm{HCHO}$ from $\mathrm{CH}_{4}$ oxidation will increase and that of $\mathrm{CH}_{3} \mathrm{OOH}$ will decrease instead (see Table 4). On the same grounds, the oceanic emission of $\mathrm{CH}_{3} \mathrm{CHO}$ exerts an indirect influence on the simulated mixing ratio of $\mathrm{HCHO}$ (and $\mathrm{CH}_{3} \mathrm{CHO}$ itself) by changing $\mathrm{NO}_{\mathrm{x}}$ mixing ratios via bromine chemistry.

\subsection{Impacts of $\mathrm{CH}_{3} \mathrm{CHO}$ emission on bromine chemistry}

Figure 3a shows the temporal evolution of bromine species in Run 1a (base run). The total mixing ratio of inorganic gaseous bromine species is calculated to be slightly over $5 \mathrm{pmol} / \mathrm{mol}$ on Day 20, originating mostly from volatilization from sea-salt aerosols with a small contribution (3.7\%) from $\mathrm{CHBr}_{3}$ degradation (see Fig. 4). This mixing ratio agrees fairly well with those observed in the MBL at Bermuda (6.7 pmol/mol; Rahn et al., 1976) and off the west African coast (ca. 1-6 pmol/mol; Kritz and Rancher, 1980; Rancher and Kritz, 1980). By analyzing aerosol samples obtained simultaneously with the gas samples, Kritz and Rancher (1980) determined the concentration of particulate bromine and its fractional deficit relative to seawater (assum- ing that all aerosol particles consist of sea-salt aerosols) to be approximately $5 \mathrm{pmol} / \mathrm{mol}$ and $32 \%$, respectively, on average. These figures are also in good agreement with those obtained in Run 1a (see Table 4). An appreciable amount of organic gaseous bromine species is also formed via $\mathrm{Br}$ initiated degradation of $\mathrm{C}_{2} \mathrm{H}_{4}, \mathrm{C}_{3} \mathrm{H}_{6}$, and $\mathrm{C}_{2} \mathrm{H}_{2}$, building up along with inorganic gaseous bromine species (see Sect. 5.3 for further discussion).

As noted before, reactions converting atomic $\mathrm{Br}$ to $\mathrm{HBr}$ are capable of regulating bromine activation in the MBL by impeding the autocatalytic halogen release. On the Day 20 of Run 1a, the conversion of atomic $\mathrm{Br}$ to $\mathrm{HBr}$ occurs at the rate of $14.0 \mathrm{pmol} / \mathrm{mol} /$ day (see Fig. 4), of which $6.5 \mathrm{pmol} / \mathrm{mol} / \mathrm{day}$ happens via Reaction (14) and $7.0 \mathrm{pmol} / \mathrm{mol} /$ day via Reaction (15). In other words, virtually half of $\mathrm{HBr}$ originates from the reaction $\mathrm{Br}+\mathrm{CH}_{3} \mathrm{CHO}$ in Run 1a, mainly because $\mathrm{CH}_{3} \mathrm{CHO}$ is 3.4 times (at $293 \mathrm{~K}$ ) more reactive toward atomic $\mathrm{Br}$ than $\mathrm{HCHO}$ is (see rate constants for G53 and G135 in Table S3 in the electronic supplement). On the daily average basis the mixing ratio of $\mathrm{HBr}$ is approximately $2 \mathrm{pmol} / \mathrm{mol}$, making up $38 \%$ of the total mixing ratio of inorganic gaseous bromine species. It appears that a significant fraction of bromine volatilized from sea-salt aerosols is sequestered as $\mathrm{HBr}$ thereby making the availability of $\mathrm{HOBr}$ and $\mathrm{BrONO}_{2}$ lower. In particular, $\mathrm{HBr}$ 
constitutes nearly $70 \%$ of inorganic gaseous bromine during the daytime when Reactions (1)-(10) operate to release reactive halogen species from sea-salt aerosols (see Fig. 5a). It is also interesting to note that about $90 \%$ of $\mathrm{HBr}$ returns to the autocatalytic cycle via either aqueous-phase reactions in the sea-salt aerosols or $\mathrm{OH}$ attack in the gas phase, whereas only $10 \%$ is irreversibly lost by dry/wet deposition (see Fig. 4).

The importance of $\mathrm{CH}_{3} \mathrm{CHO}$ for bromine chemistry in the remote $\mathrm{MBL}$ is also demonstrated by two sensitivity runs in which the oceanic emission of $\mathrm{CH}_{3} \mathrm{CHO}$ is either neglected (Run 1b) or increased by a factor of 2.2 (Run 1c). By neglecting the oceanic emission in Run $1 \mathrm{~b}$, the simulated $\mathrm{CH}_{3} \mathrm{CHO}$ mixing ratio decreases to about $10 \mathrm{pmol} / \mathrm{mol}$, which is lower by over $80 \mathrm{pmol} / \mathrm{mol}$ than that in Run 1a. The HCHO mixing ratio also decreases by $40 \mathrm{pmol} / \mathrm{mol}$ due to the secondary effect mediated by bromine chemistry (see Sect. 5.1). It follows that the partitioning of $\mathrm{HBr}$ in inorganic gaseous bromine species significantly decreases compared with Run 1a (see Fig. 5b) and that the total amount of inorganic gaseous bromine species building up on Day 20 is 2.8-fold greater than that obtained in Run 1a (see Fig. 3b and Table 4). On the other hand, the mixing ratio of $\mathrm{CH}_{3} \mathrm{CHO}$ increases to as high as $210 \mathrm{pmol} / \mathrm{mol}$ and that of $\mathrm{HCHO}$ increases by $30 \mathrm{pmol} / \mathrm{mol}$ (due to the secondary effect) in Run 1c compared with Run 1a. Consequently, the total amount of inorganic gaseous bromine species building up on Day 20 is only $42 \%$ of that obtained in Run 1a (see Fig. 3c and Table 4).

The temporal and spatial variabilities in the sea-air flux of $\mathrm{CH}_{3} \mathrm{CHO}$ and in its concentration in the MBL are not well characterized at present. Recent observations, however, suggest that the $\mathrm{CH}_{3} \mathrm{CHO}$ mixing ratio can vary from less than $70 \mathrm{pmol} / \mathrm{mol}$ to over $250 \mathrm{pmol} / \mathrm{mol}$ in the remote $\mathrm{MBL}$ (Singh et al., 2001; Wisthaler et al., 2002). Based on the numerical results presented here, we would expect that the natural variability in $\mathrm{CH}_{3} \mathrm{CHO}$ mixing ratio is an important factor for regulating autocatalytic halogen release in the remote MBL (see also Sect. 5.4).

Although the rate constant for Reaction (16) is even greater than that for Reaction (15), the mixing ratios of $\mathrm{C}_{2} \mathrm{H}_{5} \mathrm{CHO}$ (formed exclusively via $\mathrm{C}_{3} \mathrm{H}_{8}$ oxidation) are calculated to be not more than $0.2 \mathrm{pmol} / \mathrm{mol}$ in our model runs. Therefore it is tentatively concluded that $\mathrm{C}_{2} \mathrm{H}_{5} \mathrm{CHO}$ is of negligible importance for bromine chemistry in the remote MBL. There might be a possibility, however, that a substantial amount of $\mathrm{C}_{2} \mathrm{H}_{5} \mathrm{CHO}$ is emitted from the ocean along with $\mathrm{CH}_{3} \mathrm{CHO}$ and thereby exerts a substantial influence on the autocatalytic cycle. It should also be noted that the chemistry of $1-\mathrm{C}_{4} \mathrm{H}_{8}$, which provides a source of $\mathrm{C}_{2} \mathrm{H}_{5} \mathrm{CHO}$, is neglected in the present work. An appreciable amount of 1$\mathrm{C}_{4} \mathrm{H}_{8}$, although slightly smaller than that of $\mathrm{C}_{3} \mathrm{H}_{6}$, is likely to be emitted from the ocean (Bonsang, 1993; Plass-Dülmer et al., 1993). Since alkyl aldehydes tend to be more reactive toward atomic $\mathrm{Br}$ as the carbon number of alkyl group increases (Ramacher et al., 2000), measurements of $\mathrm{C}_{2} \mathrm{H}_{5} \mathrm{CHO}$ and even higher alkyl aldehydes in the air and/or underlying
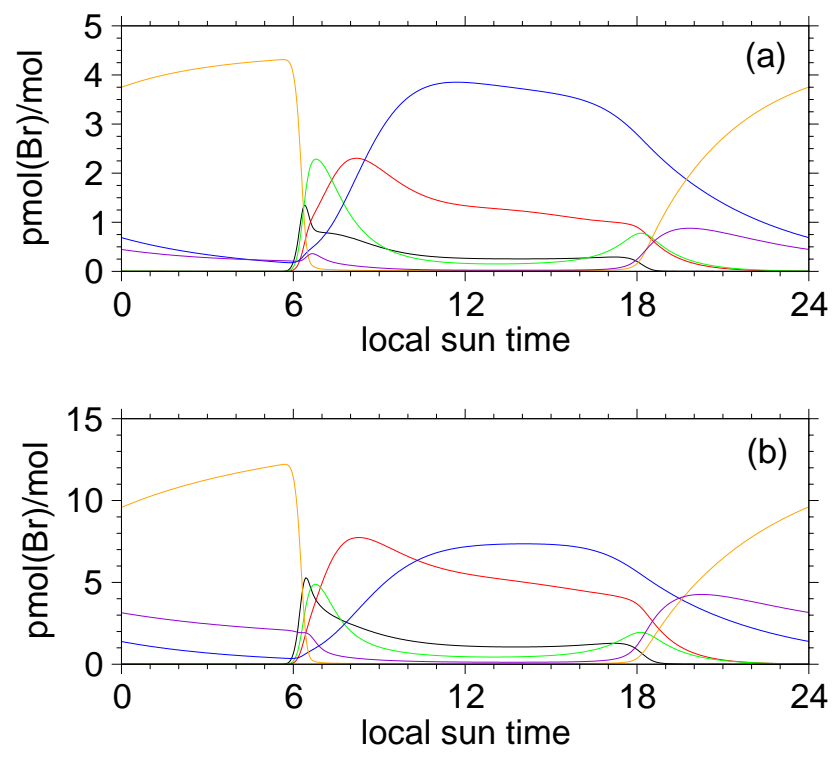

Fig. 5. Diurnal variations in the mixing ratios of major reservoirs of inorganic gaseous bromine species $(\mathrm{HBr}$, blue lines; $\mathrm{HOBr}$, red lines; $\mathrm{BrONO}_{2}$, green lines; $\mathrm{BrO}$, black lines; $\mathrm{Br}_{2}$, orange lines; and $\mathrm{BrCl}$, violet lines) simulated on Day 20 for Runs $1 \mathrm{a}$ (a) and $1 \mathrm{~b}$ (b).

seawater will be valuable for better characterizing the autocatalytic cycle in the MBL.

\subsection{Impacts of alkene emissions on bromine chemistry}

As shown in Figs. 3a-f and Table 4, organic gaseous bromine species are formed photochemically in the presence of alkenes and $\mathrm{C}_{2} \mathrm{H}_{2}$, building up along with inorganic gaseous bromine species. In Run 1a (base run), the total mixing ratio of organic gaseous bromine species formed from $\mathrm{Br}$-initiated degradation of alkenes and $\mathrm{C}_{2} \mathrm{H}_{2}$ (i.e. excluding $\mathrm{CHBr}_{3}$ and its degradation product $\mathrm{CBr}_{2} \mathrm{O}$; hereafter, the terms "organic gaseous bromine species" and "brominated organic intermediates" refer to those produced via Br-initiated degradation of alkenes and $\mathrm{C}_{2} \mathrm{H}_{2}$ ) reaches approximately $30 \%$ of that of inorganic gaseous bromine species. The brominated organic intermediates thus formed consist mainly of hydroperoxides and carbonyl compounds (see Fig. 6). In particular, three major brominated hydroperoxides, i.e. $\mathrm{CH}_{3} \mathrm{CH}(\mathrm{OOH}) \mathrm{CH}_{2} \mathrm{Br}$, $\mathrm{BrCH}_{2} \mathrm{OOH}$, and $\mathrm{BrCH}_{2} \mathrm{CH}_{2} \mathrm{OOH}$, collectively constitute $58 \%$ of the total amount of brominated organic intermediates in Run 1a. The predominance of hydroperoxides over carbonyl compounds is due to the present experimental conditions representing the low- $\mathrm{NO}_{\mathrm{x}}$ environment. Appreciable amounts of brominated carboxylic acids, percarboxylic acids, and alcohols are also formed. Although brominated carboxylic acids $\left(\mathrm{BrCH}_{2} \mathrm{COOH}\right.$ and $\left.\mathrm{CH}_{3} \mathrm{CHBrCOOH}\right)$ are capable of being dissolved in deliquesced sea-salt aerosols (see Tables S6-7), they reside mostly in the gas phase and do 


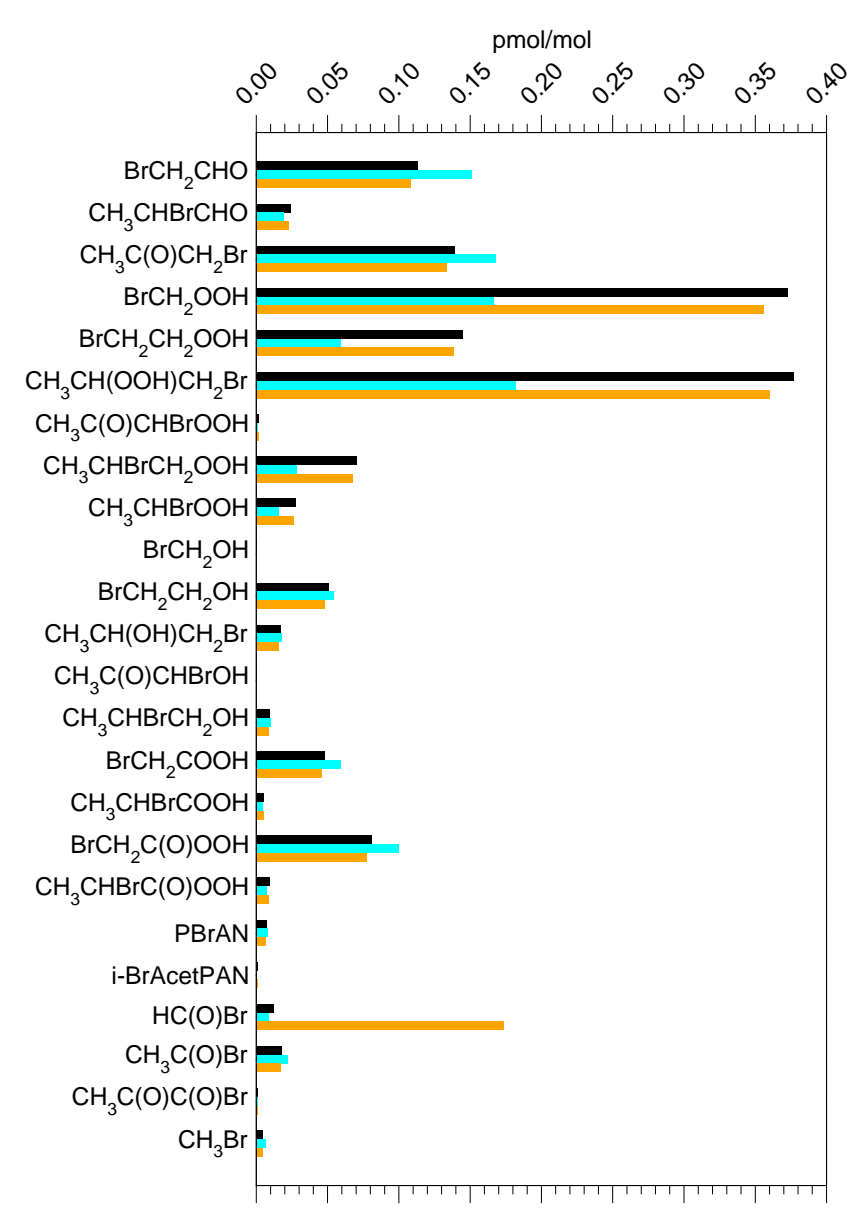

Fig. 6. Mixing ratios of brominated organic intermediates formed via $\mathrm{Br}$-initiated degradation of $\mathrm{C}_{2} \mathrm{H}_{4}, \mathrm{C}_{3} \mathrm{H}_{6}$, and $\mathrm{C}_{2} \mathrm{H}_{2}$ in Run 1a (black bars), Run 1f (blue bars), and Run 1g (orange bars). Daily averaged values on Day 20 are presented.

not make noticeable contributions to bromine content in the sea-salt aerosols.

Actually, Br-initiated $\mathrm{C}_{2} \mathrm{H}_{2}$ degradation makes a negligible contribution to the formation of brominated organic intermediates. Where the oceanic emissions of alkenes are neglected (Run 2), HCOBr formed via Reaction (53) solely makes up the brominated organic intermediate and its mixing ratio reaches only $0.007 \%$ of the total mixing ratio of inorganic gaseous bromine species (see Table 4 and Fig. 3d; see also discussion in Sect. 5.5). It follows that the simulated molar ratio of the total amount of organic gaseous bromine species to that of inorganic gaseous bromine species $\left(\mathrm{o}-\mathrm{Br}_{\mathrm{x}} / \mathrm{i}-\mathrm{Br}_{\mathrm{x}}\right.$ ratio) depends strongly on the mixing ratios of alkenes in our model runs. In Runs 3 and 5 the simulated mixing ratios of alkenes are either lower or higher by an order of magnitude than those obtained in Run 1a, leading to significant changes in $\mathrm{o}-\mathrm{Br}_{\mathrm{x}} / \mathrm{i}-\mathrm{Br}_{\mathrm{x}}$ ratio from 0.034 (Run 3) to 1.86 (Run 5) (see Table 4 and Fig. 3f). It is interesting to note that the total amount of organic gaseous bromine species can exceed that of inorganic gaseous bromine species where alkenes are so abundant as in the case of Run 5 .
As mentioned in Sect. 5.1, alkene mixing ratios typical of the remote MBL are obtained in Runs 1a-c and 4, in which cases $\mathrm{o}-\mathrm{Br}_{\mathrm{x}} / \mathrm{i}-\mathrm{Br}_{\mathrm{x}}$ ratios range from 0.13 (Run 4) to 0.41 (Run 1b). Therefore, the total mixing ratio of organic gaseous bromine species is likely to reach $10-20 \%$ or more of that of inorganic gaseous bromine species over wide regions in the MBL. Here it should be noted that $\mathrm{C}_{3} \mathrm{H}_{6}$ is likely to make a larger contribution to the formation of brominated organic intermediates than $\mathrm{C}_{2} \mathrm{H}_{4}$ does, primarily because $\mathrm{C}_{3} \mathrm{H}_{6}$ is approximately 20 times more reactive toward atomic $\mathrm{Br}$ than $\mathrm{C}_{2} \mathrm{H}_{4}$ is. In Runs 1d-e the oceanic emission of either $\mathrm{C}_{2} \mathrm{H}_{4}$ (Run 1d) or $\mathrm{C}_{3} \mathrm{H}_{6}$ (Run 1e) is neglected, while otherwise identical to the boundary conditions in Run 1a, to show the relative importance of respective alkenes for the formation of organic gaseous bromine species. The $\mathrm{o}-\mathrm{Br}_{\mathrm{x}} / \mathrm{i}-\mathrm{Br}_{\mathrm{x}}$ ratio still reaches 0.21 in Run $1 \mathrm{~d}$, whereas it drops to 0.087 in Run 1e even though the $\mathrm{C}_{2} \mathrm{H}_{4}$ mixing ratio ( $\left.~ 88 \mathrm{pmol} / \mathrm{mol}\right)$ is near the upper end of the range typical of the remote MBL.

By converting reactive inorganic bromine species to the relatively inactive organic form via reactions between alkenes and $\mathrm{Br}$ atoms, the oceanic emissions of alkenes, as with $\mathrm{CH}_{3} \mathrm{CHO}$, are capable of impeding bromine activation in the MBL. For instance, the total mixing ratio of inorganic gaseous bromine species obtained in Run 1a is only half of that obtained in Run 2 in which the oceanic emissions of $\mathrm{C}_{2} \mathrm{H}_{4}$ and $\mathrm{C}_{3} \mathrm{H}_{6}$ are both neglected (see Figs. 3a, d). Where the mixing ratios of alkenes both exceed $100 \mathrm{pmol} / \mathrm{mol}$ (Run 5 ), the amount of inorganic gaseous bromine species building up on Day 20 is an order of magnitude smaller than that in Run 2 (see Fig. 3f).

It should be noted that the conversion of atomic $\mathrm{Br}$ into brominated organic intermediates via reactions with alkenes occurs at the rate more than an order of magnitude slower than the conversion of atomic $\mathrm{Br}$ into $\mathrm{HBr}$ via reactions with aldehydes in Run 1a (see Fig. 4). Once formed, however, brominated organic intermediates are fairly resistant to further degradation to regenerate inorganic bromine species. Their degradation to inorganic bromine takes place mostly via decomposition of brominated alkoxy radicals (Reactions 33-34) and brominated acetyl radicals (Reaction 41) and via heterogeneous reactions of $\mathrm{HCOBr}$ on the aerosol surface. An average timescale for brominated organic intermediates to regenerate inorganic bromine is estimated to be $57 \mathrm{~h}$ in Run 1a, by dividing the sum of the production rates of $\mathrm{Br}$ atoms, $\mathrm{HBr}$, and $\mathrm{Br}^{-}$from brominated organic intermediates into their total concentration. This timescale is much longer than that for the reentry of $\mathrm{HBr}$ into the autocatalytic cycle, i.e. Reactions (1)-(10), by aerosol uptake or via $\mathrm{OH}$ attack, which is estimated to be $3.7 \mathrm{~h}$. Among the brominated organic intermediates formed in Run 1a, $59 \%$ undergoes futher degradation to regenerate inorganic bromine species and the remainder is lost via dry/wet deposition. Then the dry/wet deposition of brominated organic intermediates makes up $22 \%$ of the total deposited bromine in the gaseous form. In this way the chemical stability of 
Table 5. Sources and sinks for brominated hydroperoxides, $\mathrm{CH}_{3} \mathrm{CH}(\mathrm{OOH}) \mathrm{CH}_{2} \mathrm{Br}, \mathrm{BrCH}_{2} \mathrm{CH}_{2} \mathrm{OOH}$, and $\mathrm{BrCH}_{2} \mathrm{OOH}$, on Day 20 in $\mathrm{Run}$ 1a. The relative contribution of each loss pathway to the overall loss of each compound is also given in parentheses.

\begin{tabular}{|c|c|}
\hline \multicolumn{2}{|l|}{$\left[\mathrm{CH}_{3} \mathrm{CH}(\mathrm{OOH}) \mathrm{CH}_{2} \mathrm{Br}\right]=0.377 \mathrm{pmol} / \mathrm{mol}$} \\
\hline $\begin{array}{l}\text { - Source - } \\
\mathrm{CH}_{3} \mathrm{CH}(\mathrm{OO}) \mathrm{CH}_{2} \mathrm{Br}+\mathrm{HO}_{2} \\
-\mathrm{Sink}- \\
\mathrm{CH}_{3} \mathrm{CH}(\mathrm{OOH}) \mathrm{CH}_{2} \mathrm{Br}+h v \rightarrow 0.86 \times \mathrm{CH}_{3} \mathrm{COCH}_{2} \mathrm{Br}+0.14 \times \mathrm{BrCH}_{2} \mathrm{OO}+\text { products } \\
\mathrm{CH}_{3} \mathrm{CH}(\mathrm{OOH}) \mathrm{CH}_{2} \mathrm{Br}+\mathrm{OH} \rightarrow \mathrm{CH}_{3} \mathrm{C}(\mathrm{OO}) \mathrm{CH}_{2} \mathrm{Br}+\mathrm{H}_{2} \mathrm{O} \\
\mathrm{CH}_{3} \mathrm{CH}(\mathrm{OOH}) \mathrm{CH}_{2} \mathrm{Br}+\mathrm{OH} \rightarrow \mathrm{CH}_{3} \mathrm{C}(\mathrm{O}) \mathrm{CH}_{2} \mathrm{Br}+\mathrm{OH}+\mathrm{H}_{2} \mathrm{O} \\
\text { dry deposition }\end{array}$ & $\begin{array}{l}0.512 \mathrm{pmol} / \mathrm{mol} / \text { day } \\
0.039 \mathrm{pmol} / \mathrm{mol} / \text { day }(7.7 \%) \\
0.114 \mathrm{pmol} / \mathrm{mol} / \text { day }(22.2 \%) \\
0.251 \mathrm{pmol} / \mathrm{mol} / \text { day }(49.0 \%) \\
0.108 \mathrm{pmol} / \mathrm{mol} / \text { day }(21.2 \%)\end{array}$ \\
\hline \multicolumn{2}{|l|}{$\left[\mathrm{BrCH}_{2} \mathrm{CH}_{2} \mathrm{OOH}\right]=0.145 \mathrm{pmol} / \mathrm{mol}$} \\
\hline $\begin{array}{l}- \text { Source }- \\
\mathrm{BrCH}_{2} \mathrm{CH}_{2} \mathrm{OO}+\mathrm{HO}_{2} \\
-\mathrm{Sink}- \\
\mathrm{BrCH}_{2} \mathrm{CH}_{2} \mathrm{OOH}+h v \rightarrow \mathrm{BrCH}_{2} \mathrm{CHO}+\mathrm{HO}_{2}+\mathrm{OH} \\
\mathrm{BrCH}_{2} \mathrm{CH}_{2} \mathrm{OOH}+\mathrm{OH} \rightarrow \mathrm{BrCH}_{2} \mathrm{CH}_{2} \mathrm{OO}+\mathrm{H}_{2} \mathrm{O} \\
\mathrm{BrCH}_{2} \mathrm{CH}_{2} \mathrm{OOH}+\mathrm{OH} \rightarrow \mathrm{BrCH}_{2} \mathrm{CHO}+\mathrm{OH}+\mathrm{H}_{2} \mathrm{O} \\
\text { dry deposition }\end{array}$ & $\begin{array}{l}0.147 \mathrm{pmol} / \mathrm{mol} / \text { day } \\
0.015 \mathrm{pmol} / \mathrm{mol} / \text { day }(10.2 \%) \\
0.043 \mathrm{pmol} / \mathrm{mol} / \text { day }(29.5 \%) \\
0.047 \mathrm{pmol} / \mathrm{mol} / \text { day }(31.9 \%) \\
0.042 \mathrm{pmol} / \mathrm{mol} / \text { day }(28.5 \%)\end{array}$ \\
\hline$\left[\mathrm{BrCH}_{2} \mathrm{OOH}\right]=0.373 \mathrm{pmol} / \mathrm{mol}$ & \\
\hline $\begin{array}{l}- \text { Source }- \\
\mathrm{BrCH}_{2} \mathrm{OO}+\mathrm{HO}_{2} \\
-\mathrm{Sink}- \\
\mathrm{BrCH}_{2} \mathrm{OOH}+h v \rightarrow 0.99 \times \mathrm{Br}+0.01 \times \mathrm{HCOBr}+\text { products } \\
\mathrm{BrCH}_{2} \mathrm{OOH}+\mathrm{OH} \rightarrow \mathrm{BrCH} 2 \mathrm{OO}+\mathrm{H}_{2} \mathrm{O} \\
\mathrm{BrCH}_{2} \mathrm{OOH}+\mathrm{OH} \rightarrow \mathrm{HCOBr}+\mathrm{OH}+\mathrm{H}_{2} \mathrm{O} \\
\text { dry deposition }\end{array}$ & $\begin{array}{l}0.353 \mathrm{pmol} / \mathrm{mol} / \text { day } \\
0.037 \mathrm{pmol} / \mathrm{mol} / \text { day }(10.5 \%) \\
0.107 \mathrm{pmol} / \mathrm{mol} / \text { day }(30.5 \%) \\
0.101 \mathrm{pmol} / \mathrm{mol} / \text { day }(28.6 \%) \\
0.107 \mathrm{pmol} / \mathrm{mol} / \text { day }(30.4 \%)\end{array}$ \\
\hline
\end{tabular}

brominated organic intermediates will allow their buildup in the air, sequestering bromine from a reactive inorganic pool as well as providing an additional route for the depositional loss of bromine from the air.

Based largely on estimated rate constants, numerical predictions made in the present work should be subject to errors associated with such estimates. In particular, the rate constants of $\mathrm{OH}$-attacks/photolysis of brominated hydroperoxides exclusively rely on estimation, even though they constitute more than half of brominated organic intermediates (see Fig. 6).

Table 5 presents the budgets of three main brominated hydroperoxides formed in Run 1a. It is estimated that the photochemical loss of these hydroperoxides are generally dominated by $\mathrm{OH}$ attacks with an order of magnitude smaller contributions from photolysis and that their photochemical lifetimes do not differ much one another $(22-36 \mathrm{~h})$. As described in Sect. S10 in the electronic supplement, the rate constants of $\mathrm{OH}$ attacks on brominated hydroperoxides are estimated based on structure-activity relationships (SAR) with relevant parameters taken from Kwok and Atkinson (1995), Jenkin et al. (1997), and Saunders et al. (2003). Kwok and Atkin- son (1995) alerted that the extended use of the SAR method, as employed in the present work, can lead to errors in the estimated rate constants by a factor of two or more. However, the errors as large as an order of magnitude would be quite unlikely to occur for the majority of reactions. On the other hand, our estimation for the photolysis rate of brominated hydroperoxides (identical to that of $\mathrm{CH}_{3} \mathrm{OOH}$ ) is solely based on the experimental evidence that absorption cross sections of $\mathrm{CH}_{3} \mathrm{OOH}, \mathrm{HOCH} \mathrm{H}_{2} \mathrm{OOH}$, and $\mathrm{ClCH}_{2} \mathrm{CH}_{2} \mathrm{OOH}$ virtually identical to one another (see Sect. S10 in the electronic supplement). In a sensitivity run in which the absorption cross sections of brominated hydroperoxides are red-shifted by $50 \mathrm{~nm}$ relative to those of $\mathrm{CH}_{3} \mathrm{OOH}$ (Run 1f), the 24-hour average $\mathbf{J}$ value for brominated hydroperoxides increases by a factor of 15, making their overall photochemical lifetimes shortened by a factor of 2-3. This results in a twofold decrease in the mixing ratios of brominated hydroperoxides, while accompanying a slight increase in the mixing ratios of brominated carbonyl compounds and their degradation products such as $\mathrm{BrCH}_{2} \mathrm{COOH}$ (see Fig. 6). Overall, an appreciable amount of organic brominated intermediates, reaching $1.1 \mathrm{pmol} / \mathrm{mol}\left(\mathrm{o}-\mathrm{Br}_{\mathrm{x}} / \mathrm{i}-\mathrm{Br}_{\mathrm{x}}\right.$ ratio is 0.18$)$, also builds up 
Table 6. Sources and sinks for brominated carbonyl compounds, $\mathrm{CH}_{3} \mathrm{COCH}_{2} \mathrm{Br}, \mathrm{BrCH}_{2} \mathrm{CHO}$, and $\mathrm{HCOBr}$, on Day 20 in $\mathrm{Run} 1 \mathrm{a}$. For the sake of simplicity, common pathways are lumped together and those contributing by less than $0.2 \%$ of the overall production/loss of each compound are disregarded. The relative contribution of each common production/loss pathway is given in parentheses.

\begin{tabular}{|c|c|}
\hline \multicolumn{2}{|l|}{$\left[\mathrm{CH}_{3} \mathrm{COCH}_{2} \mathrm{Br}\right]=0.139 \mathrm{pmol} / \mathrm{mol}$} \\
\hline $\begin{array}{l}\text { - Source - } \\
\mathrm{CH}_{3} \mathrm{CH}(\mathrm{OO}) \mathrm{CH}_{2} \mathrm{Br}+\mathrm{NO} / \mathrm{CH}_{3} \mathrm{OO} \\
\mathrm{CH}_{3} \mathrm{CH}(\mathrm{OOH}) \mathrm{CH}_{2} \mathrm{Br}+\mathrm{OH} / h v \\
\mathrm{CH}_{3} \mathrm{CH}(\mathrm{OH}) \mathrm{CH}_{2} \mathrm{Br}+\mathrm{OH} \\
-\mathrm{Sink}- \\
\mathrm{CH}_{3} \mathrm{COCH} \mathrm{CH}_{2} \mathrm{Br}+h \rightarrow \\
\quad 0.625 \times \mathrm{BrCH} \mathrm{H}_{2} \mathrm{OO}+0.25 \times \mathrm{BrCH}_{2} \mathrm{C}(\mathrm{O}) \mathrm{OO}+0.125 \times \mathrm{Br}+\text { products } \\
\mathrm{CH}_{3} \mathrm{COCH} \mathrm{CH}_{2} \mathrm{Br}+\mathrm{OH} \rightarrow \mathrm{CH}_{3} \mathrm{COCHBrOO}+\mathrm{H}_{2} \mathrm{O} \\
\text { dry deposition }\end{array}$ & $\begin{array}{l}0.523 \mathrm{pmol} / \mathrm{mol} / \text { day }(97.3 \%) \\
0.0034 \mathrm{pmol} / \mathrm{mol} / \text { day }(0.6 \%) \\
0.011 \mathrm{pmol} / \mathrm{mol} / \text { day }(2.0 \%)\end{array}$ \\
\hline$\left[\mathrm{BrCH}_{2} \mathrm{CHO}\right]=0.113 \mathrm{pmol} / \mathrm{mol}$ & \\
\hline $\begin{array}{l}- \text { Source }- \\
\mathrm{BrCH}_{2} \mathrm{CH}_{2} \mathrm{OO}+\mathrm{NO} / \mathrm{CH}_{3} \mathrm{OO} \\
\mathrm{BrCH}_{2} \mathrm{CH}_{2} \mathrm{OOH}+\mathrm{OH} / h v \\
\mathrm{BrCH}_{2} \mathrm{CH}_{2} \mathrm{OH}+\mathrm{OH} \\
\mathrm{Br}+\text { acrolein } \\
-\mathrm{Sink}- \\
\mathrm{BrCH}_{2} \mathrm{CHO}+h v \rightarrow 0.997 \times \mathrm{BrCH}_{2} \mathrm{OO}+0.003 \times \mathrm{CH}_{3} \mathrm{Br}+\text { products } \\
\mathrm{BrCH}_{2} \mathrm{CHO}+\mathrm{OH} \rightarrow 0.5 \times \mathrm{BrCH}_{2} \mathrm{C}(\mathrm{O}) \mathrm{OO}+0.25 \times\left(\mathrm{BrCH}_{2} \mathrm{OO}+\mathrm{Br}\right)+\text { products } \\
\text { dry/wet deposition }\end{array}$ & $\begin{array}{l}0.105 \mathrm{pmol} / \mathrm{mol} / \text { day }(55.8 \%) \\
0.062 \mathrm{pmol} / \mathrm{mol} / \text { day }(32.7 \%) \\
0.0079 \mathrm{pmol} / \mathrm{mol} / \text { day }(4.2 \%) \\
0.014 \mathrm{pmol} / \mathrm{mol} / \text { day }(7.2 \%) \\
0.104 \mathrm{pmol} / \mathrm{mol} / \text { day }(55.5 \%) \\
0.037 \mathrm{pmol} / \mathrm{mol} / \text { day }(19.5 \%) \\
0.047 \mathrm{pmol} / \mathrm{mol} / \text { day }(24.8 \%)\end{array}$ \\
\hline$[\mathrm{HCOBr}]=0.012 \mathrm{pmol} / \mathrm{mol}$ & \\
\hline $\begin{array}{l}- \text { Source }- \\
\mathrm{BrCH}_{2} \mathrm{OO}+\mathrm{HO}_{2} \\
\mathrm{BrCH}_{2} \mathrm{O}+\mathrm{O}_{2} \\
\mathrm{BrCH}_{2} \mathrm{OOH}+\mathrm{OH} \\
\mathrm{Br}+\mathrm{C}_{2} \mathrm{H}_{2} \\
-\mathrm{Sink}- \\
\mathrm{HCOBr} \rightarrow \mathrm{HBr}+\mathrm{CO} \text { (on aerosols) } \\
\mathrm{HCOBr}+\mathrm{OH} / h v \rightarrow \mathrm{Br}+\text { products } \\
\text { dry/wet deposition }\end{array}$ & $\begin{array}{l}0.039 \mathrm{pmol} / \mathrm{mol} / \text { day }(27.2 \%) \\
0.00084 \mathrm{pmol} / \mathrm{mol} / \text { day }(0.6 \%) \\
0.101 \mathrm{pmol} / \mathrm{mol} / \text { day }(69.8 \%) \\
0.0035 \mathrm{pmol} / \mathrm{mol} / \text { day }(2.4 \%) \\
0.134 \mathrm{pmol} / \mathrm{mol} / \text { day }(93.0 \%) \\
0.005 \mathrm{pmol} / \mathrm{mol} / \text { day }(3.5 \%) \\
0.005 \mathrm{pmol} / \mathrm{mol} / \text { day }(3.5 \%)\end{array}$ \\
\hline
\end{tabular}

in Run $1 \mathrm{f}$ and the total mixing ratio of inorganic gaseous bromine species is simulated to be only $14 \%$ higher than that in Run 1a (see Table 4).

In the remote $\mathrm{MBL}$ with low $\mathrm{NO}_{\mathrm{x}}$ concentrations, a large fraction of alkenes that react with $\mathrm{Br}$ atoms forms brominated hydroperoxides, whose further degradation results in the formation of brominated carbonyl compounds. Then the decomposition of brominated alkoxy/acetyl radicals, which are formed via further degradation of brominated carbonyl compounds, provides a main pathway to regenerate inorganic bromine ( $\mathrm{Br}$ atoms) from brominated organic intermediates (see Tables 5-6). In this manner multiple reaction steps are generally involved in regenerating inorganic bromine species from brominated organic oxygenates, so that the simulated overall impacts of alkenes on halogen activation will not change significantly by errors in the rate estimates for specific reactions.

One may expect a possibility that halogenated hydroperoxides (and other halogenated organic oxygenates formed along with them) are decomposed more promptly than estimated in the present work to regenerate inorganic halogen species via some unknown mechanisms. In their modeling study concerning "bromine explosion" in the Arctic boundary layer, McConnell et al. (1992) even assumed that brominated hydroperoxides and other brominated organic oxygenates are effectively scavenged by the surfaces of snow and aerosols and are then converted to $\mathrm{Br}_{2}$ via reaction with $\mathrm{Br}^{-}$:

Organic- $\mathrm{Br}+\mathrm{Br}^{-} \rightarrow \mathrm{Br}_{2}+$ products.

However, the feasibility of such reactions has never been explored with laboratory experiments. We would expect that 
such reactions, if they do happen, proceed very slowly as in the case of aqueous-phase reactions between PAA and $\mathrm{Cl}^{-} / \mathrm{Br}^{-}$and do not exert any noticeable influences on the behaviors of halogenated organic oxygenates (see Sect. 5.6). It should also be noted that wall reactions of $\mathrm{ClCH}_{2} \mathrm{OOH}$ and $\mathrm{BrCH}_{2} \mathrm{OOH}$ were unobservable in previous chamber experiments (Chen et al., 1995; Wallington et al., 1996).

In this respect, the reactive uptake coefficient $(\gamma)$ as large as 0.1 is already assigned for the heterogeneous reaction of $\mathrm{HCOBr}$ to give $\mathrm{HBr}+\mathrm{CO}$ in Run 1a (see Sect. 3.2). The rapid heterogeneous loss makes the chemical lifetime of $\mathrm{HCOBr}$ shorter than $3 \mathrm{~h}$ and provides an important pathway to regenerate inorganic bromine from brominated organic intermediates (see Table 6 and Fig. 4). By decreasing $\gamma$ to $8 \times 10^{-4}$ as in the case of heterogeneous reactions of acetyl halides (Run $1 \mathrm{~g}$ ), the $\mathrm{HCOBr}$ mixing ratio is simulated be more than an order of magnitude higher than that in Run 1a (see Fig. 6). Although a consequent change in the total mixing ratio of inorganic gaseous bromine species is less than 5\% (see Table 4), this result warrants further experimental studies in light of the heterogeneous reactions of halogenated organic oxygenates (especially hydroperoxides) on/in aerosols and cloud droplets.

\subsection{Additional model runs with the fixed mixing ratios of $\mathrm{HCHO} / \mathrm{CH}_{3} \mathrm{CHO} / \mathrm{C}_{2} \mathrm{H}_{4} / \mathrm{C}_{3} \mathrm{H}_{6}$}

As shown in the previous section, the oceanic alkene emissions are capable of impeding bromine activation in the MBL by forming brominated organic intermediates ("direct" influence). Actually, the oceanic emissions of alkenes also result in the increase in the mixing ratios of $\mathrm{CH}_{3} \mathrm{CHO}$ and $\mathrm{HCHO}$ in the MBL (see Sect. 5.1). This could represent an additional factor for impeding bromine activation ("indirect" influence). In order to separate contributions from the "direct" and "indirect" influences, model runs are conducted in which the mixing ratios of $\mathrm{C}_{2} \mathrm{H}_{4}, \mathrm{C}_{3} \mathrm{H}_{6}, \mathrm{HCHO}$, and $\mathrm{CH}_{3} \mathrm{CHO}$ are specified rather than simulated in the model (Runs 6a-d; see Tables 3 and 7). In Runs $6 a$ and $6 \mathrm{~b}$ the mixing ratios of $\mathrm{C}_{2} \mathrm{H}_{4}$, $\mathrm{C}_{3} \mathrm{H}_{6}, \mathrm{HCHO}$, and $\mathrm{CH}_{3} \mathrm{CHO}$ are specified to the daily average values on Day 20 in Runs 2 and 1a, respectively. Accordingly, the total mixing ratios of inorganic gaseous bromine species simulated on Day 20 in Runs $6 \mathrm{a}(\sim 11 \mathrm{pmol} / \mathrm{mol})$ and $6 \mathrm{~b}(\sim 5 \mathrm{pmol} / \mathrm{mol})$ are very close to those in Runs 2 and $1 \mathrm{a}$, respectively. In Run $6 c$ the mixing ratios of $\mathrm{C}_{2} \mathrm{H}_{4}$ and $\mathrm{C}_{3} \mathrm{H}_{6}$ are fixed at $0 \mathrm{pmol} / \mathrm{mol}$ (the same as Run $6 \mathrm{a}$ ), whereas those of $\mathrm{HCHO}$ and $\mathrm{CH}_{3} \mathrm{CHO}$ are increased to $301.2 \mathrm{pmol} / \mathrm{mol}$ and $94.7 \mathrm{pmol} / \mathrm{mol}$, respectively, matching those in Run $6 \mathrm{~b}$. On the other hand, in Run $6 \mathrm{~d}$ the mixing ratios of $\mathrm{C}_{2} \mathrm{H}_{4}$ and $\mathrm{C}_{3} \mathrm{H}_{6}$ are fixed at the same values as those in Run $6 \mathrm{~b}$, whereas the mixing ratios of $\mathrm{HCHO}$ and $\mathrm{CH}_{3} \mathrm{CHO}$ are decreased to $265.6 \mathrm{pmol} / \mathrm{mol}$ and $80.2 \mathrm{pmol} / \mathrm{mol}$, respectively, matching those in Run 6a. Consequently, the total mixing ratios of inorganic gaseous bromine species is simulated to be $\sim 8 \mathrm{pmol} / \mathrm{mol}$ and $\sim 7 \mathrm{pmol} / \mathrm{mol}$ in Runs $6 \mathrm{c}$ and $6 \mathrm{~d}$, respec-
Table 7. Total mixing ratios of inorganic gaseous bromine species $\left(\mathrm{i}-\mathrm{Br}_{\mathrm{X}}\right)$ in Runs $6 \mathrm{a}-\mathrm{d}$. Daily averaged values on Day 20 are presented.

\begin{tabular}{lcccc}
\hline & Run 6a & Run 6b & Run 6c & Run 6d \\
\hline $\mathrm{C}_{2} \mathrm{H}_{4}{ }^{a, b}$ & 0.0 & 89.9 & 0.0 & 89.9 \\
$\mathrm{C}_{3} \mathrm{H}_{6}{ }^{a, b}$ & 0.0 & 12.6 & 0.0 & 12.6 \\
$\mathrm{HCHO}^{a, b}$ & 265.6 & 301.2 & 301.2 & 265.6 \\
$\mathrm{CH}_{3} \mathrm{CHO}^{a, b}$ & 80.2 & 94.7 & 94.7 & 80.2 \\
$\mathrm{i}_{-} \mathrm{Br}_{\mathrm{x}}{ }^{a}$ & 11.15 & 5.26 & 7.87 & 6.75 \\
\hline
\end{tabular}

Notes:

${ }^{a}$ Unit: $\mathrm{pmol} / \mathrm{mol}$;

${ }^{b}$ Mixing ratios are fixed at given values

tively, implying that the increase in $\mathrm{CH}_{3} \mathrm{CHO}$ and $\mathrm{HCHO}$ mixing ratios by secondary effects also plays an important role in the impacts of oceanic alkene emissions on bromine activation.

To survey the dependence of bromine activation on each of $\mathrm{CH}_{3} \mathrm{CHO}, \mathrm{C}_{2} \mathrm{H}_{4}$, and $\mathrm{C}_{3} \mathrm{H}_{6}$ mixing ratios within their typical ranges in the remote MBL (see Table 1), three sets of parameter sweep experiments are also performed. In each experiment multiple model runs are conducted, taking $[\mathrm{HCHO}]=300 \mathrm{pmol} / \mathrm{mol},\left[\mathrm{CH}_{3} \mathrm{CHO}\right]=90 \mathrm{pmol} / \mathrm{mol}$, $\left[\mathrm{C}_{2} \mathrm{H}_{4}\right]=30 \mathrm{pmol} / \mathrm{mol}$, and $\left[\mathrm{C}_{3} \mathrm{H}_{6}\right]=15 \mathrm{pmol} / \mathrm{mol}$ as a baseline condition. Here the sensitivities of model behaviors on either $\mathrm{CH}_{3} \mathrm{CHO}$ mixing ratio (from 0 to $250 \mathrm{pmol} / \mathrm{mol}$; Run 7a), $\mathrm{C}_{2} \mathrm{H}_{4}$ mixing ratio (from 0 to $100 \mathrm{pmol} / \mathrm{mol}$; Run $7 \mathrm{~b}$ ), or $\mathrm{C}_{3} \mathrm{H}_{6}$ mixing ratio (from 0 to $30 \mathrm{pmol} / \mathrm{mol}$; Run $7 \mathrm{c}$ ) are examined. Under the baseline condition the total mixing ratio of inorganic gaseous bromine species is simulated to be $5.7 \mathrm{pmol} / \mathrm{mol}$ with the $\mathrm{o}-\mathrm{Br}_{\mathrm{x}} / \mathrm{i}-\mathrm{Br}_{\mathrm{x}}$ ratio of 0.29 . As shown in Figs. 7a and c, the degree of bromine activation depends quite strongly on changes in $\mathrm{CH}_{3} \mathrm{CHO}$ and $\mathrm{C}_{3} \mathrm{H}_{6}$ mixing ratios. Within the probable range of $\mathrm{CH}_{3} \mathrm{CHO}$ mixing ratios in the remote MBL $(70-250 \mathrm{pmol} / \mathrm{mol})$ the total mixing ratio of inorganic gaseous bromine species ranges between 1.9$7.2 \mathrm{pmol} / \mathrm{mol}$ with $\mathrm{o}-\mathrm{Br}_{\mathrm{x}} / \mathrm{i}-\mathrm{Br}_{\mathrm{x}}$ ratio ranging between 0.20 0.31 . Within the probable range of $\mathrm{C}_{3} \mathrm{H}_{6}$ mixing ratios in the remote MBL $(2-30 \mathrm{pmol} / \mathrm{mol})$, the total mixing ratio of inorganic gaseous bromine species ranges between $4.5-$ $7.6 \mathrm{pmol} / \mathrm{mol}$ with $\mathrm{o}-\mathrm{Br}_{\mathrm{x}} / \mathrm{i}-\mathrm{Br}_{\mathrm{x}}$ ratio ranging between $0.06-$ 0.54. A change in $\mathrm{C}_{2} \mathrm{H}_{4}$ mixing ratio has a weaker influence on bromine activation than those in $\mathrm{CH}_{3} \mathrm{CHO}$ and $\mathrm{C}_{3} \mathrm{H}_{6}$ mixing ratios do. As $\mathrm{C}_{2} \mathrm{H}_{4}$ mixing ratio is increased from 5 to $90 \mathrm{pmol} / \mathrm{mol}$ (sweeping the probable range in the remote MBL), the total mixing ratio of inorganic gaseous bromine species decreases by only about $10 \%$ (see Fig. 7b).

Finally, it should be noted that $\mathrm{NO}_{\mathrm{x}}$ mixing ratio is also an important factor for determining the $\mathrm{o}-\mathrm{Br}_{\mathrm{x}} / \mathrm{i}-\mathrm{Br}_{\mathrm{x}}$ ratio. In the model runs presented so far, $\mathrm{NO}_{\mathrm{y}}$ flux from the free troposphere was specified to $1.5 \times 10^{9}$ molecule $\mathrm{cm}^{-2} \mathrm{~s}^{-1}$ to 

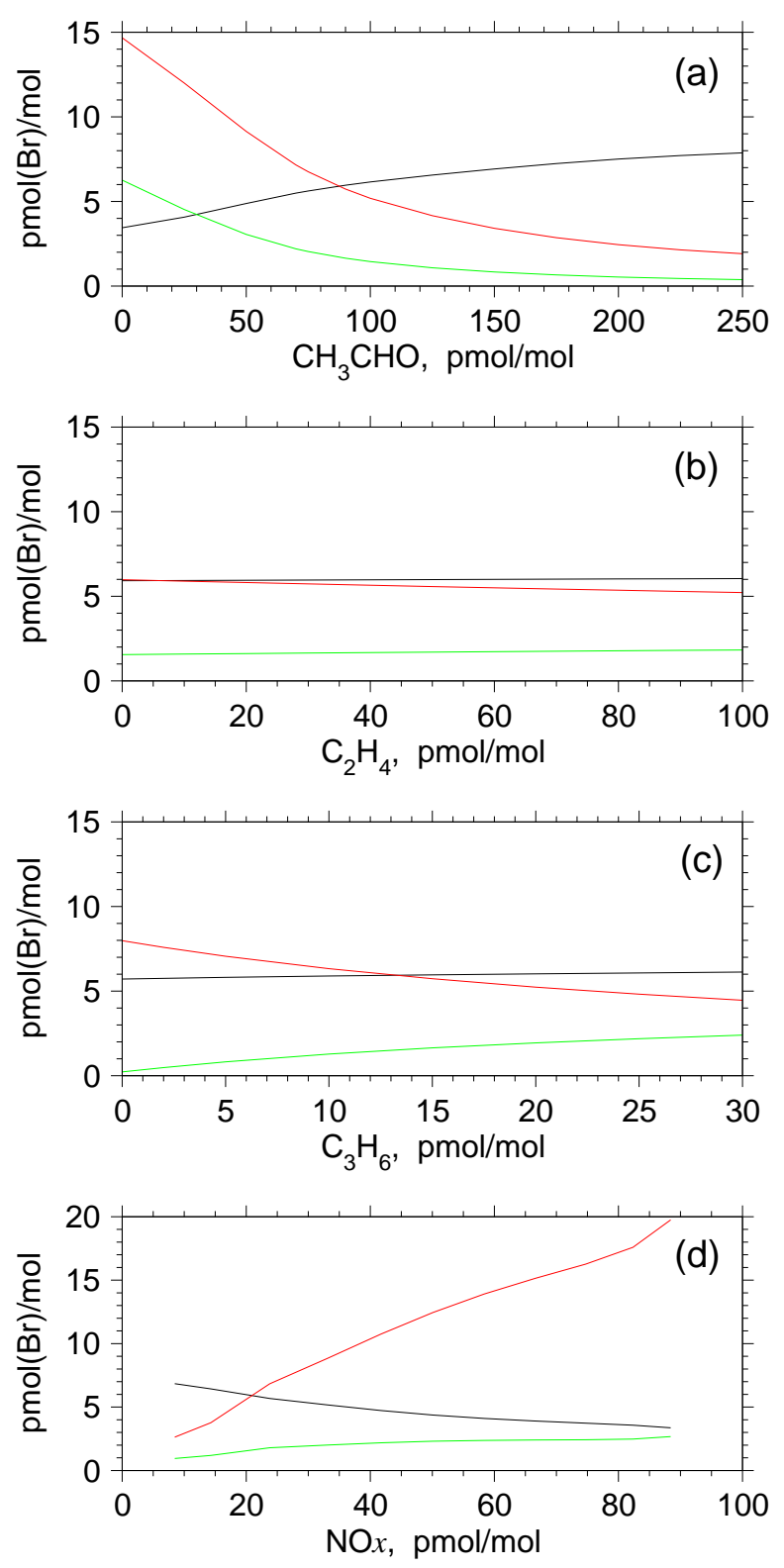

Fig. 7. The total mixing ratios of $\mathrm{Br}^{-}$in sea-salt aerosols (black lines), those of inorganic gaseous bromine species (red lines), and those of brominated organic intermediates (green lines) obtained on Day 20 in parameter sweep experiments: (a) Run 7a, (b) Run $7 b$, (c) Run 7c, and (d) Run 7d. The results obtained in Run 7d are presented as a function of simulated $\mathrm{NO}_{\mathrm{x}}$ mixing ratio (daily average on Day 20) rather than $\mathrm{NO}_{\mathrm{y}}$ flux.

yield the $\mathrm{NO}_{\mathrm{x}}$ mixing ratios of about $10-20 \mathrm{pmol} / \mathrm{mol}$ (see Table 4), which represent the pristine environment remote from the continents (Gregory et al., 1996; Heikes et al., 1996). Run $7 \mathrm{~d}$ is a parameter sweep experiment in which the mixing ratios of $\mathrm{HCHO}, \mathrm{CH}_{3} \mathrm{CHO}, \mathrm{C}_{2} \mathrm{H}_{4}$, and $\mathrm{C}_{3} \mathrm{H}_{6}$ are fixed at $300,90,30$, and $15 \mathrm{pmol} / \mathrm{mol}$, respectively, while changing the free tropospheric $\mathrm{NO}_{\mathrm{y}}$ flux between $5 \times 10^{8}-$ $1 \times 10^{10}$ molecule $\mathrm{cm}^{-2} \mathrm{~s}^{-1}$. The simulated $\mathrm{NO}_{\mathrm{x}}$ mixing ra- tio then decreases down to $8 \mathrm{pmol} / \mathrm{mol}$ or increases up to $88 \mathrm{pmol} / \mathrm{mol}$. The latter is to represent the $\mathrm{NO}_{\mathrm{x}}$ mixing ratios in the MBL under the relatively polluted conditions (Kondo et al., 1997). Under these conditions the simulated o- $\mathrm{Br}_{\mathrm{x}} / \mathrm{i}$ $\mathrm{Br}_{\mathrm{x}}$ ratio ranges between $0.14-0.36$, which decreases with increasing $\mathrm{NO}_{\mathrm{x}}$ mixing ratio (see Fig. 7d). The partitioning of hydroperoxides in brominated organic intermediates decreases significantly, whereas that of carbonyl compounds increases instead, with increasing $\mathrm{NO}_{\mathrm{x}}$ mixing ratio. For instance, in the situation where the $\mathrm{NO}_{\mathrm{x}}$ mixing ratio is simulated to be $88 \mathrm{pmol} / \mathrm{mol}$, three major hydroperoxides (i.e. $\mathrm{CH}_{3} \mathrm{CH}(\mathrm{OOH}) \mathrm{CH}_{2} \mathrm{Br}, \mathrm{BrCH}_{2} \mathrm{OOH}$, and $\left.\mathrm{BrCH}_{2} \mathrm{CH}_{2} \mathrm{OOH}\right)$ collectively constitute $40 \%$ of the total amount of brominated organic intermediates (reduced by 18 percent points from Run 1a), whereas $\mathrm{CH}_{3} \mathrm{COCH}_{2} \mathrm{Br}$ becomes the most abundant brominated organic intermediate making up $25 \%$ of the total. Thus, Br-initiated alkene degradation is more likely to bypass the formation of hydroperoxides and to directly produce carbonyl compounds with increasing $\mathrm{NO}_{\mathrm{x}}$ mixing ratio, thereby reducing the number of reaction steps to regenerate inorganic bromine species (cf. Tables 5-6). Hence the impacts of oceanic alkene emissions on the autocatalytic cycle will be generally stronger in the pristine MBL than in the relatively polluted MBL.

\subsection{Impacts of $\mathrm{C}_{2} \mathrm{H}_{2}$ on bromine activation}

In their modeling study Sander et al. (1997) found that $\mathrm{C}_{2} \mathrm{H}_{2}$ as well as $\mathrm{C}_{2} \mathrm{H}_{4}$ can effectively impede the "bromine explosion" in the springtime Arctic boundary layer, given that all the $\mathrm{Br}$ atoms reacting with $\mathrm{C}_{2} \mathrm{H}_{2}$ produce organicallybound bromine compound(s) (most likely $\mathrm{HCOBr}$ ) and that the product(s) are completely inert against further degradation to regenerate inorganic bromine species.

As determined experimentally by Yarwood et al. (1991) and Ramacher et al. (2001), however, less than $20 \%$ of the reaction $\mathrm{Br}+\mathrm{C}_{2} \mathrm{H}_{2}$ results in $\mathrm{HCOBr}$ formation, whereas the remainder gives inorganic bromine species such as $\mathrm{HBr}$ or $\mathrm{Br}$ atoms (see Reaction 53). Besides, $\mathrm{HCOBr}$ is likely to hydrolyze rapidly on aerosols to give $\mathrm{HBr}$ (see Sect. 3.2.3). Thus, in our model runs, $\mathrm{C}_{2} \mathrm{H}_{2}$ exerts no more than a marginal influence on bromine activation. As $\mathrm{C}_{2} \mathrm{H}_{2}$ mixing ratio fixed in each run is raised from $35 \mathrm{pmol} / \mathrm{mol}$ (Run 1a) to $200 \mathrm{pmol} / \mathrm{mol}$ (Run $1 \mathrm{~h}$ ) to represent an air mass under a relatively strong continental influence (e.g. Koppmann et al., 1992), the calculated total mixing ratio of inorganic gaseous bromine species gets lower only by $1 \%$ (see Table 4 ). Even where the reactive uptake coefficient of $\mathrm{HCOBr}$ hydrolysis on aerosols is reduced from 0.1 to $8 \times 10^{-4}$, the impact of $\mathrm{C}_{2} \mathrm{H}_{2}$ is still very small; in this case, the calculated total mixing ratio of inorganic gaseous bromine species gets lower by $2 \%$, as $\mathrm{C}_{2} \mathrm{H}_{2}$ mixing ratio is raised from $35 \mathrm{pmol} / \mathrm{mol}$ (Run $1 \mathrm{~g}$ ) to $200 \mathrm{pmol} / \mathrm{mol}$ (Run $1 \mathrm{i})$. 
5.6 PAA as a trigger of autocatalytic halogen release from sea-salt aerosols

PAA is formed primarily via $\mathrm{OH}$-initiated $\mathrm{CH}_{3} \mathrm{CHO}$ oxidation in the gas phase (Reactions (54)-(55)). This compound is potentially important for triggering the autocatalytic halogen release from sea-salt aerosols, since it is capable of oxidizing $\mathrm{Br}^{-}$(and probably $\mathrm{Cl}^{-}$as well) in the aqueous phase (Fortnum et al., 1960). To our knowledge, no reported data exist as to the concentrations of PAA in the MBL. However, its production and loss kinetics in the gas- and aqueousphases have been characterized relatively well by experimental studies (see Sect. 3.4) and, besides, the concentration of its precursor, $\mathrm{CH}_{3} \mathrm{CHO}$, can be constrained by recent observational data (Singh et al., 2001; Wisthaler et al., 2002). In our model runs the calculated mixing ratio of PAA varies between 27 to $157 \mathrm{pmol} / \mathrm{mol}$, depending on the mixing ratios of $\mathrm{CH}_{3} \mathrm{CHO}$ and $\mathrm{NO}_{\mathrm{x}}$ (see Table 4). Then the aqueousphase reactions of PAA considered in the present work (Reaction 57-59) take place so slowly that the aqueous-phase concentrations of PAA in aerosols are virtually in Henry's law equilibrium with its gas-phase concentrations.

Table 8 presents the production rates of reactive halogen species via reactions of potential importance for triggering the autocatalytic halogen release in Run 1a (base run), in which the simulated mixing ratio of PAA on Day 20 is close to its initial mixing ratio, i.e. $80 \mathrm{pmol} / \mathrm{mol}$. Although the analysis is made on Day 20, the relative importance of each trigger reaction (except for the importance of $\mathrm{Br}^{-}$-involving reactions relative to that of $\mathrm{Cl}^{-}$-involving counterparts) during the first 6 model hours does not differ significantly from that during the nighttime of Day 20. It should also be noted that, although over $90 \%$ of $\mathrm{HOCl}$ formed in sea salt is consumed to oxidize $\mathrm{S}(\mathrm{IV}), 5-10 \%$ of $\mathrm{HOCl}$ reacts with $\mathrm{Br}^{-}$to give reactive bromine species.

As in the cases of earlier model studies (Sander and Crutzen, 1996; Vogt et al., 1996), the reaction $\mathrm{Br}^{-}+\mathrm{HSO}_{5}^{-}$ and the self-reaction of $\mathrm{Br}_{2}^{-}$are primarily important for triggering the autocatalytic cycle. They are the consequences of radical chain reactions initiated by the uptake of either $\mathrm{OH}$ (during the daytime) or $\mathrm{NO}_{3}$ (during the nighttime) from the gas phase. Photolysis of $\mathrm{NO}_{3}^{-}$also results in the formation of $\mathrm{OH}$ radicals and augments the $\mathrm{OH}$ concentrations in sea-salt aerosols (von Glasow et al., 2002a). The next important process as a trigger of autocatalytic halogen release is $\mathrm{CHBr}_{3}$ degradation in the gas phase, which subsequently gives $\mathrm{HOBr}$ and $\mathrm{BrONO}_{2}$ via Reactions (8)-(10) (Tang and McConnell, 1996). The oxidation of halide ions by PAA occurs at the rates even slower than that of $\mathrm{Br}^{-}$oxidation by $\mathrm{O}_{3}$, reaching no more than a few percent of the rates of the radical-initiated processes during the daytime. The relative importance of reactions involving PAA becomes greater during the nighttime, although it is still on the order of $10 \%$ of the total. It follows that the oxidation of halide ions by PAA
Table 8. Production rates of reactive halogen species via reactions triggering the autocatalytic halogen release from sea-salt aerosols as simulated in Run $1 \mathrm{a}^{a}$. Values averaged over the nighttime (00:0006:00, 18:00-24:00 local sun time) and over the daytime (06:0018:00 local sun time) on Day 20 are presented.

\begin{tabular}{lccc}
\hline Reaction(s) & Product & Nighttime & Daytime \\
\hline $\mathrm{Br}^{-}+\mathrm{HSO}_{5}^{-} b$ & $\mathrm{HOBr}$ & $1.4 \times 10^{-3}$ & $1.5 \times 10^{-2}$ \\
$\mathrm{Cl}^{-}+\mathrm{HSO}_{5}^{-} b$ & $\mathrm{HOCl}$ & $3.0 \times 10^{-3}$ & $6.7 \times 10^{-2}$ \\
$\mathrm{Br}_{2}^{-}+\mathrm{Br}_{2}^{-} b$ & $\mathrm{Br}_{2}$ & $5.4 \times 10^{-4}$ & $3.8 \times 10^{-2}$ \\
$\mathrm{Cl}_{2}^{-}+\mathrm{Cl}_{2}^{-} b$ & $\mathrm{Cl}_{2}$ & $2.2 \times 10^{-5}$ & $3.0 \times 10^{-3}$ \\
$\mathrm{Br}^{-}+\mathrm{O}_{3} b$ & $\mathrm{HOBr}$ & $1.4 \times 10^{-3}$ & $1.1 \times 10^{-3}$ \\
$\mathrm{Br}^{-}+\mathrm{PAA}^{b}$ & $\mathrm{HOBr}$ & $4.1 \times 10^{-4}$ & $3.7 \times 10^{-4}$ \\
$\mathrm{Cl}^{-}+\mathrm{PAA}^{b}$ & $\mathrm{HOCl}$ & $7.6 \times 10^{-4}$ & $7.6 \times 10^{-4}$ \\
$\mathrm{Br}^{-}+\mathrm{HNO}_{4}{ }^{b}$ & $\mathrm{HOBr}$ & $9.7 \times 10^{-7}$ & $1.6 \times 10^{-5}$ \\
$\mathrm{Cl}^{-}+\mathrm{HNO}_{4}{ }^{b}$ & $\mathrm{HOCl}$ & $2.2 \times 10^{-6}$ & $4.3 \times 10^{-5}$ \\
$\mathrm{CHBr}_{3}$ degradation $^{c}$ & $\mathrm{Br}$ & $5.6 \times 10^{-6}$ & $7.7 \times 10^{-3}$ \\
\hline
\end{tabular}

Notes:

${ }^{a}$ Unit: $\mathrm{pmol}(\mathrm{Br}) / \mathrm{mol} / \mathrm{hour}$ or $\mathrm{pmol}(\mathrm{Cl}) / \mathrm{mol} / \mathrm{hour}$;

$b$ Integrated over aerosol size bins except for the largest-size bin, which remains alkaline over the whole simulation time;

${ }^{c}$ The formation of $\mathrm{Br}$ atoms via $\mathrm{CHBr}_{3}$ photolysis, $\mathrm{OH}-$ and $\mathrm{Cl}-$ attacks on $\mathrm{CHBr}_{3}$, and $\mathrm{CBr}_{2} \mathrm{O}$ photolysis is accounted for, whereas the formation of $\mathrm{HBr}$ via $\mathrm{CHBr}_{3}$ photolysis is not.

during the nighttime can exert some marginal influence on the autocatalytic cycle if initiated shortly after sunrise.

We believe that PAA mixing ratios are quite reasonably simulated in the present model runs, but the measurements of PAA in the MBL are needed to better assess its impact.

\subsection{Implications for chemistry of DMS, $\mathrm{NO}_{\mathrm{x}}$, and $\mathrm{O}_{3}$}

As demonstrated in Sects. 5.2-5.4, the oceanic emissions of $\mathrm{CH}_{3} \mathrm{CHO}$ and alkenes will significantly impede the autocatalytic halogen release from sea salt in the remote MBL. The simulated mixing ratios of reactive bromine species can thus differ by a factor of two or more with or without the oceanic emissions of these compounds (see Table 4 and Fig. 3). For instance, Figs. 8a-b show diurnal variations in the simulated concentrations of $\mathrm{BrO}$ radicals and $\mathrm{Cl}$ atoms on Day 20 for Runs 1a-b and 2. In Run 1a, which is our base run with the mixing ratios of $\mathrm{CH}_{3} \mathrm{CHO}$ and alkenes typical of the remote $\mathrm{MBL}$, the simulated $\mathrm{BrO}$ mixing ratio is generally below $1 \mathrm{pmol} / \mathrm{mol}$, rising to $1.3 \mathrm{pmol} / \mathrm{mol}$ shortly after sunrise. Where the oceanic emissions of alkenes are switched off (Run 2), BrO mixing ratio is calculated to be somewhat higher, ranging $<1-3.4 \mathrm{pmol} / \mathrm{mol}$ during the daytime. Run $1 \mathrm{~b}$ yields a result with the most activated bromine chemistry among the model runs conducted in the present work, by neglecting the oceanic $\mathrm{CH}_{3} \mathrm{CHO}$ emission (see Table 4); in this run, $\mathrm{BrO}$ mixing ratio is generally between $1-2 \mathrm{pmol} / \mathrm{mol}$ during the daytime, peaking at $5.3 \mathrm{pmol} / \mathrm{mol}$ shortly after 

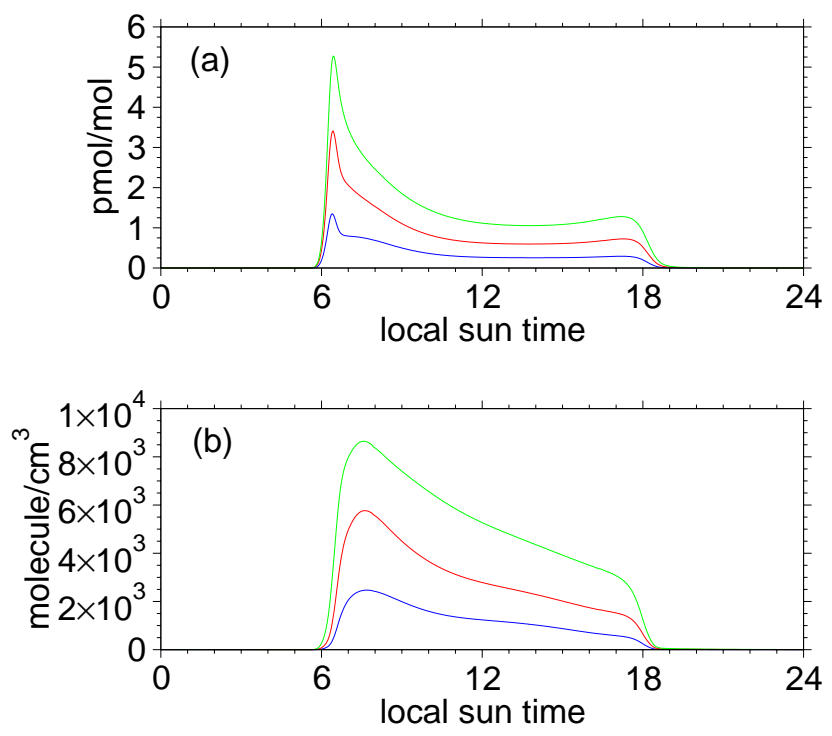

Fig. 8. Diurnal variations in $\mathrm{BrO}$ mixing ratios (a) and $\mathrm{Cl}$-atom concentrations (b) on Day 20 for Runs 1a (blue lines), 1b (green lines), and 2 (red lines).

sunrise. These levels of $\mathrm{BrO}$ are not detected with adequate confidence by currently available measurement techniques, except for short duration in the early morning when $\mathrm{BrO}$ mixing ratio well exceeds $2 \mathrm{pmol} / \mathrm{mol}$, but most likely within the range of variations taking place in the remote MBL (see Sect. 1). The simulated concentrations of $\mathrm{Cl}$ atoms also change according to the degree of bromine activation, ranging between $10^{3}-10^{4}$ molecule $/ \mathrm{cm}^{3}$ during the daytime. These numbers do not contradict those inferred from the observed concentrations of hydrocarbons and/or halocarbons and their correlations in the remote MBL (Rudolph et al., 1996, 1997; Singh et al., 1996a,b; Wingenter et al., 1996, 1999).

Quite interestingly, the impacts of halogen (especially bromine) chemistry on the budgets of DMS, $\mathrm{NO}_{\mathrm{x}}$, and $\mathrm{O}_{3}$ are still evident in Run 1a (see Table 4). Compared with Run $1 \mathrm{j}$, which is a sensitivity run for Run 1a with halogen chemistry being switched off, the simulated mixing ratio of DMS is lower by $20 \%$, reflecting the additional photochemical loss via reactions with $\mathrm{BrO}$ radicals and $\mathrm{Cl}$ atoms that constitutes $24 \%$ of the total loss (see also Fig. 9). Here the reactions of DMS with $\mathrm{Br}$ atoms and $\mathrm{ClO}$ radicals are not accounted for in our reaction scheme, since the former reaction does not result in $\mathrm{H}$-abstraction from DMS at atmospheric temperatures (Ingham et al., 1999; Nakano et al., 2001) and the rate constant of the latter reaction is approximately 30 times smaller than that of the reaction $\mathrm{BrO}+\mathrm{DMS}$ (Barnes et al., 1991). The mixing ratio of $\mathrm{NO}_{\mathrm{x}}$ is also lower by $22 \%$ in Run 1a compared with that in Run $1 \mathrm{j}$, owing to the enhanced loss of $\mathrm{NO}_{2}$ via Reaction (10) followed by aerosol uptake. Then, by the combined effects of enhanced loss via bromine

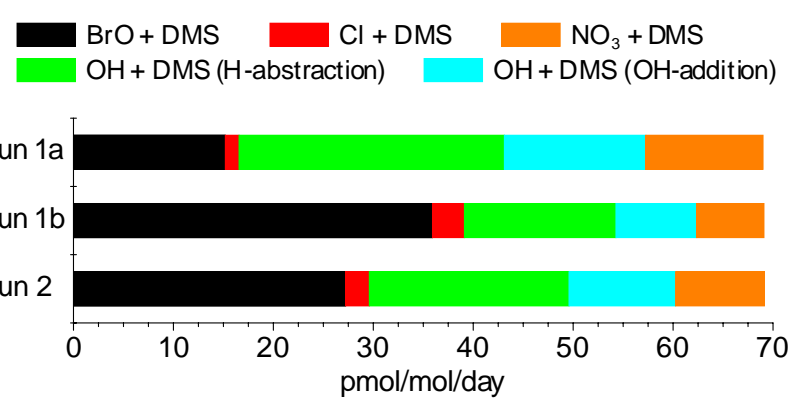

Fig. 9. DMS oxidation pathways on Day 20 for Runs $1 \mathrm{a}-\mathrm{b}$ and 2.

chemistry and decreased production at lower $\mathrm{NO}_{\mathrm{x}}$ concentrations (Sander et al., 1999; Toyota et al., 2001), the net chemical loss rate of $\mathrm{O}_{3}$ increases from $0.71 \mathrm{nmol} / \mathrm{mol} /$ day to $1.09 \mathrm{nmol} / \mathrm{mol} / \mathrm{day}$. This difference in the net production rate will expand to $1.14-1.52 \mathrm{nmol} / \mathrm{mol}(5.7-7.6 \%$ of the absolute amount, i.e. $20 \mathrm{nmol} / \mathrm{mol}$ ) in $\mathrm{O}_{3}$ mixing ratio, taking timescales for the exchange of air mass in the MBL with that in the free troposphere to be 3-4 days (Ayers and Galbally, 1995). In Runs $1 b$ and 2 the impacts of halogen chemistry are of course larger: reactions with $\mathrm{BrO}$ radicals and $\mathrm{Cl}$ atoms constitute 57\% (Run 1b) and 43\% (Run 2) of the overall photochemical loss of DMS (see Fig. 9); $\mathrm{NO}_{\mathrm{x}}$ mixing ratios are lower by $54 \%$ (Run 1 b) and $41 \%$ (Run 2) compared with that in Run $1 \mathrm{j}$; and the net chemical loss of $\mathrm{O}_{3}$ reaches as high as $1.79 \mathrm{nmol} / \mathrm{mol} /$ day and $1.46 \mathrm{nmol} / \mathrm{mol} /$ day in Runs $1 \mathrm{~b}$ and 2, respectively (see Table 4).

These results suggest that $\mathrm{CH}_{3} \mathrm{CHO}$ and alkenes of oceanic origin should be carefully treated in the models of reactive halogen chemistry involving sea-salt aerosols. From the results presented in Sects. 5.2-5.4, we would expect that naturally occurring variabilities in the oceanic emissions of $\mathrm{CH}_{3} \mathrm{CHO}$ and alkenes lead to changes in the amount of reactive halogen species to be higher or lower than that in Run 1a by a factor of about two. Taken together, reactive halogen chemistry is likely to mediate a link between the oceanic emissions of VOCs and the behaviors of compounds that are sensitive to halogen chemistry such as DMS, $\mathrm{NO}_{\mathrm{x}}$, and $\mathrm{O}_{3}$ in the MBL.

\section{Conclusions}

In the present work, the reaction scheme of the multiphase photochemical box model SEAMAC (size-SEgregated Aerosol model for Marine Air Chemistry) was updated to achieve a near-explicit description of oxidative degradation of up to $\mathrm{C}_{3}$-hydrocarbons $\left(\mathrm{CH}_{4}, \mathrm{C}_{2} \mathrm{H}_{6}, \mathrm{C}_{3} \mathrm{H}_{8}, \mathrm{C}_{2} \mathrm{H}_{4}, \mathrm{C}_{3} \mathrm{H}_{6}\right.$, and $\mathrm{C}_{2} \mathrm{H}_{2}$ ) initiated by reactions with $\mathrm{OH}$ radicals, $\mathrm{Cl}$ - and $\mathrm{Br}$-atoms, and $\mathrm{O}_{3}$. Based on the new reaction scheme it was shown numerically that $\mathrm{CH}_{3} \mathrm{CHO}$ and alkenes (especially $\mathrm{C}_{3} \mathrm{H}_{6}$ ) of oceanic origin strongly impede the autocatalytic halogen release from sea salt in the remote MBL. 
To our knowledge, this is the first study of its kind addressing the impacts of $\mathrm{C}_{3} \mathrm{H}_{6}$ on halogen chemistry in the lower troposphere. Also shown was the significant buildup of brominated organic oxygenates formed via reactions between atomic $\mathrm{Br}$ and alkenes. Over wide regions over the ocean, the total mixing ratios of brominated organic compounds thus produced are likely to reach $10-20 \%$ or more of those of inorganic gaseous bromine species.

The photochemical production (or loss) of VOCs in seawater should be associated, although not directly, with biogenic activities in the ocean (see Sect. 2). In this regard, spatial and temporal variabilities in their sea-air fluxes should be better characterized in relation to DMS fluxes. As shown by earlier modeling studies, halogen activation will be significantly enhanced via the heterogeneous recycling of inorganic halogen species on fine-mode sulfate aerosols, most of which in the remote MBL originate from DMS oxidation (Vogt et al., 1996; von Glasow et al., 2002a). Although a recent numerical study by von Glasow and Crutzen (2004) highlighted significant uncertainty in predicting links between DMS oxidation and the formation/growth of aerosols, observations have suggested that DMS emissions from the ocean and subsequent photochemical processes are important for the growth of fine-mode aerosols in the remote MBL (e.g. Ayers et al., 1991; Andreae et al., 1995; Huebert et al., 1996; Bates et al., 1998). Therefore, if the sea-air fluxes of VOCs and DMS correlate with each other, their impacts on halogen activation would cancel out to some extent. Otherwise, halogen activation is likely to show a marked contrast between VOCsdominant and DMS-dominant air masses.

Actually, some uncertainties are present in the existing observational data for aldehydes and alkenes in the air, owing to their artifact production in inlet systems or during the canister storage (Donahue and Prinn, 1993; Wisthaler et al., 2002). Hence it is also important to improve the present capabilities of measuring these species in the air, in order to better assess their impacts on reactive halogen chemistry.

To date, the impacts of the oceanic VOCs emissions have been discussed within the context of $\mathrm{HO}_{\mathrm{x}}-\mathrm{NO}_{\mathrm{x}}$ chemistry and/or organic acids formation (e.g. Arlander et al., 1990; Donahue and Prinn, 1990; Singh et al., 2001). Quite interestingly, the model runs conducted in the present work indicate that the concentrations of reactive halogen species are more sensitively influenced by the oceanic emissions of $\mathrm{CH}_{3} \mathrm{CHO}$ and alkenes than the concentration of $\mathrm{OH}$ radicals is. This implies that the behaviors of compounds sensitive to halogen chemistry (such as DMS, $\mathrm{NO}_{\mathrm{x}}$, and $\mathrm{O}_{3}$ ) can be controlled indirectly by the oceanic emissions of VOCs in the MBL.
Acknowledgements. We wish to thank O. Wild, M. Takigawa, and $\mathrm{K}$. Sudo for valuable discussion and comments to advance technical aspects associated with this work, T. Benter for communicating their experimental data prior to publication, and J. G. Calvert for discussing their experimental data on acrolein photolysis. We are also grateful to G. V. Buxton, H.-G. Libuda, J. Hirokawa, A. Aranda, Y. Sadanaga, H. Tanimoto, and K. Takahashi for providing valuable information which helped our chemical mechanism development and to $\mathrm{S}$. Kato for providing useful information on PTR-MS technique. We also thank the editor and two reviewers for helpful comments to improve this paper.

Edited by: R. Sander

\section{References}

Andreae, M. O., Elbert, W., and de Mora, S. J.: Biogenic sulfur emissions and aerosols over the tropical South Atlantic, 3. Atmospheric dimethylsulfide, aerosols and cloud condensation nuclei, J. Geophys. Res., 100, 11 335-11 356, 1995.

Arlander, D. W., Cronn, D. R., Farmer, J. C., Menzia, F. A., and Westberg, H. H.: Gaseous oxygenated hydrocarbons in the remote marine troposphere, J. Geophys. Res., 95, 16391-16403, 1990.

Atkinson, R., Baulch, D. L., Cox, R. A., Hampson, R. F., Jr., Kerr, J. A., Rossi, M. J., and Troe, J.: Evaluated Kinetic, Photochemical and Heterogeneous Data for Atmospheric Chemistry: Supplement V, IUPAC Subcommittee on Gas Kinetic Data Evaluation for Atmospheric Chemistry, J. Phys. Chem. Ref. Data, 26, 521-1011, 1997.

Atkinson, R., Baulch, D. L., Cox, R. A., Hampson, R. F., Jr., Kerr, J. A., Rossi, M. J., and Troe, J.: Evaluated Kinetic and Photochemical Data for Atmospheric Chemistry, Organic Species: Supplement VII, IUPAC Subcommittee on Gas Kinetic Data Evaluation for Atmospheric Chemistry, J. Phys. Chem. Ref. Data, 28, 191-393, 1999.

Ayers, G. P. and Galbally, I. E.: A preliminary estimation of a boundary layer-free troposphere entrainment velocity at Cape Grim, in Baseline 92, edited by Dick, A. L. and Fraser, P. J., pp. 10-15, Bureau of Meteorology, Australia, 1995.

Ayers, G. P., Ivey, J. P., and Gillett, R. W.: Coherence between seasonal cycles of dimethyl sulphide, methanesulphonate and sulphate in marine air, Nature, 349, 404-406, 1991.

Ayers, G. P., Gillett, R. W., Granek, H., de Serves, C., and Cox, R. A.: Formaldehyde production in clean marine air, Geophys. Res. Lett., 24, 401-404, 1997.

Baboukas, E. D., Kanakidou, M., and Mihalopoulos, N.: Carboxylic acids in gas and particulate phase above the Atlantic Ocean, J. Geophys. Res., 105, 14 459-14 471, 2000.

Baker, A. R., Turner, S. M., Broadgate, W. J., Thompson, A., McFiggans, G. B., Vesperini, O., Nightingale, P. D., Liss, P. S., and Jickells, T. D.: Distribution and sea-air fluxes of biogenic trace gases in the eastern Atlantic Ocean, Global Biogeochem. Cycles, 14, 871-886, 2000.

Barnes, I., Bastian, V., Becker, K. H., Overath, R., and Zhu, T.: Rate constants for the reactions of $\mathrm{Br}$ atoms with a series of alkanes, alkenes, and alkynes in the presence of $\mathrm{O}_{2}$, Int. J. Chem. Kinet., 21, 499-517, 1989. 
Barnes, I., Bastian, V., Becker, K. H., and Overath, R. D.: Kinetic studies of the reactions of $\mathrm{IO}, \mathrm{BrO}$, and $\mathrm{ClO}$ with dimethylsulfide, Int. J. Chem. Kinet., 23, 579-591, 1991.

Bates, T. S., Kapustin, V. N., Quinn, P. K., Covert, D. S., Coffmann, D. J., Mari, C., Durkee, P. A., De Bruyn, W. J., and Saltzman, E.: Processes controlling the distribution of aerosol particles in the lower marine boundary layer during the First Aerosol Characterization Experiment (ACE 1), J. Geophys. Res., 103, 1636916383, 1998.

Bedjanian, Y., Poulet, G., and Le Bras, G.: Low-pressure study of the reactions of $\mathrm{Br}$ atoms with alkenes. 1. Reactions with propene, J. Phys. Chem. A, 102, 5867-5875, 1998.

Bedjanian, Y., Poulet, G., and Le Bras, G.: Low-pressure study of the reactions of $\mathrm{Br}$ atoms with alkenes. 2. Reactions with ethene and trans-2-butene, J. Phys. Chem. A, 103, 4026-4033, 1999.

Bierbach, A., Barnes, I., and Becker, K. H.: Rate coefficients for the gas-phase reactions of bromine radicals with a series of alkenes, dienes, and aromatic hydrocarbons at $298 \pm 2 \mathrm{~K}$, Int. J. Chem. Kinet., 28, 565-577, 1996.

Bierbach, A., Barnes, I., and Becker, K. H.: FT-IR product study of the gas-phase $\mathrm{Br}$-initiated oxidation of trans-2-butene under atmospheric conditions between 246 and 298 K, Tellus, 49B, 566582, 1997.

Bilde, M., Wallington, T. J., Ferronato, C., Orlando, J J., Tyndall, G. S., Estupiñan, E., and Haberkorn, S.: Atmospheric chemistry of $\mathrm{CH}_{2} \mathrm{BrCl}, \mathrm{CHBrCl}_{2}, \mathrm{CHBr}_{2} \mathrm{Cl}, \mathrm{CF}_{3} \mathrm{CHBrCl}$, and $\mathrm{CBr}_{2} \mathrm{Cl}_{2}$, J. Phys. Chem. A, 102, 1976-1986, 1998.

Bilde, M., Orlando, J. J., Tyndall, G. S., Wallington, T. J., Hurley, M. D., and Kaiser, E. W.: FT-IR product studies of the $\mathrm{Cl}$-initiated oxidation of $\mathrm{CH}_{3} \mathrm{Cl}$ in the presence of $\mathrm{NO}$, J. Phys. Chem. A, 103, 3963-3968, 1999.

Blanchard, D. C. and Woodcock, A. H.: The production, concentration, and vertical distribution of the sea-salt aerosol, Ann. N. Y. Acad. Sci., 338, 330-347, 1980.

Bonsang, B.: Hydrocarbons emission from the ocean, in The Tropospheric Chemistry of Ozone in the Polar Regions, NATO ASI Series I7, (Eds.) Niki, H. and Becker, K. H., pp. 251-260, SpringerVerlag, Berlin, 1993.

Bonsang, B., Kanakidou, M., Lambert, G., and Monfray, P.: The marine source of $\mathrm{C}_{2}-\mathrm{C}_{6}$ aliphatic hydrocarbons, J. Atmos. Chem., 6, 3-20, 1988.

Boucher, O., Moulin, C., Belviso, S., Aumont, O., Bopp, L., Cosme, E., von Kuhlmann, R., Lawrence, M. G., Pham, M., Reddy, M. S., Sciare, J., and Venkataraman, C.: DMS atmospheric concentrations and sulphate aerosol indirect radiative forcing: a sensitivity study to the DMS source representation and oxidation, Atmos. Chem. Phys., 3, 49-65, 2003,

SRef-ID: 1680-7324/acp/2003-3-49.

Burkholder, J. B., Gilles, M. K., Gierczak, T, and Ravishankara, A. R.: The atmospheric degradation of 1-bromopropane $\left(\mathrm{CH}_{3} \mathrm{CH}_{2} \mathrm{CH}_{2} \mathrm{Br}\right)$ : The photochemistry of bromoacetone, Geophys. Res. Lett., 29(17), 1822, doi:10.1029/2002GL014712, 2002.

Carver, G. D., Brown, P. D., and Wild, O.: The ASAD atmospheric chemistry integration package and chemical reaction database, Comp. Phys. Comm., 105, 197-215, 1997.

Chand, D., Lal, S., and Naja, M.: Variations of ozone in the marine boundary layer over the Arabian Sea and the Indian Ocean during the 1998 and 1999 INDOEX campaigns, J. Geophys. Res.,
108(D6), 4190, doi:10.1029/2001JD001589, 2003.

Chen, J., Catoire, V., and Niki, H.: Mechanistic study of the $\mathrm{BrCH}_{2} \mathrm{O}$ radical degradation in 700 Torr air, Chem. Phys. Lett., 245, 519-528, 1995.

Chen, J., Young, V., Catoire, V., and Niki, H.: FTIR spectroscopic studies of the mechanisms of the halogen atom initiated oxidation of haloacetaldehydes, J. Phys. Chem., 100, 6580-6586, 1996.

Chin, M., Rood, R. B., Allen, D. J., Andreae, M. O., Thompson, A. M., Lin, S. -J., Atlas, R. M., and Ardizzone, J. V.: Processes controlling dimethylsulfide over the ocean: Case studies using a 3-D model driven by assimilated meteorological fields, J. Geophys. Res., 103, 8341-8353, 1998.

DeMore, W. B., Sander, S. P., Golden, D. M., Hampson, R. F., Kurylo, M. J., Howard, C. J., Ravishankara, A. R., Kolb, C. E., and Molina, M. J.: Chemical Kinetics and Photochemical Data for Use in Stratospheric Modeling, Evaluation 12, JPL Publication 97-4, Jet Propulsion Laboratory, Pasadena, California, 1997.

Dickerson, R. R., Rhoads, K. P., Carsey, T. P., Oltmans, S. J., Burrows, J. P., and Crutzen, P. J.: Ozone in the remote marine boundary layer: A possible role for halogens, J. Geophys. Res., 104, 21 385-21 395, 1999.

Donahue, N. M. and Prinn, R. G.: Nonmethane hydrocarbon chemistry in the remote marine boundary layer, J. Geophys. Res., 95, 18 387-18 411, 1990.

Donahue, N. M. and Prinn, R. G.: In situ nonmethane hydrocarbon measurements on SAGA 3, J. Geophys. Res., 98, 16915-16932, 1993.

Dowideit, P., Mertens, R., and von Sonntag, C.: Non-hydrolytic decay of formyl chloride into $\mathrm{CO}$ and $\mathrm{HCl}$ in aqueous solution, J. Am. Chem. Soc., 118, 11 288-11 292, 1996.

Finlayson-Pitts, B. J., Livingston, F. E., and Berko, H. N.: Ozone destruction and bromine photochemistry at ground level in the Arctic spring, Nature, 343, 622-625, 1990.

Fortnum, D. H., Battaglia, C. J. Cohen, S. R., and Edwards, J. O.: The kinetics of the oxidation of halide ions by monosubstituted peroxides, J. Am. Chem. Soc., 82, 778-782, 1960.

Garratt, J. R., The Atmospheric Boundary Layer, Cambridge University Press, Cambridge, 1992.

Gregory, G. L., Bachmeier, A. S., Blake, D. R., Heikes, B. G., Thornton, D. C., Bandy, A. R., Bradshaw, J. D., and Kondo, Y.: Chemical signatures of aged Pacific marine air: Mixed layer and free troposphere as measured during PEM-West A, J. Geophys. Res., 101, 1727-1742, 1996.

Hedgecock, I. M., Pirrone, N., Sprovieri, F., and Pesenti, E.: Reactive gaseous mercury in the marine boundary layer: modelling and experimental evidence of its formation in the Mediterranean region, Atmos. Environ., 37(S1), 41-49, 2003.

Heikes, B., Lee, M., Jacob, D., Talbot, R., Bradshaw, J., Singh, H., Blake, D., Anderson, B., Fuelberg, H., and Thompson, A. M.: Ozone, hydroperoxides, oxides of nitrogen, and hydrocarbon budgets in the marine boundary layer over the South Atlantic, J. Geophys. Res., 101, 24 221-24 234, 1996.

Hindmarsh, A. C.: ODEPACK, A systematized collection of ode solvers, in Scientific Computing, edited by Stepleman, R. S., et al., pp. 55-64, North-Holland, Amsterdam, 1983.

Hirokawa, J., Onaka, J., Kajii, Y., and Akimoto, H.: Heterogeneous processes involving sodium halide particles and ozone: Molecular bromine release in the marine boundary layer in the absence 
of nitrogen oxides, Geophys. Res. Lett., 25, 2449-2452, 1998.

Huebert, B. J, Wylie, D. J., Zhuang, L., and Heath J. A.: Production and loss of methanesulfonate and non-sea salt sulfate in the equatorial Pacific marine boundary layer, Geophys. Res. Lett., 23, 737-740, 1996

Impey, G. A., Shepson, P. B., Hastie, D. R., and Barrie, L. A.: Measurement technique for the determination of photolyzable chlorine and bromine in the atmosphere, J. Geophys. Res., 102, 15 999-16 004, 1997.

Ingham, T., Bauer, D., Sander, R., Crutzen, P. J., and Crowley, J. N.: Kinetics and products of the reactions $\mathrm{BrO}+\mathrm{DMS}$ and $\mathrm{Br}+$ DMS at 298 K, J. Phys. Chem. A, 103, 7199-7209, 1999.

James, J. D., Harrison, R. M., Savage, N. H., Allen, A. G., Grenfell, J. L., Allan, B. J., Plane, J. M. C., Hewitt, C. N., Davison, B., and Robertson, L.: Quasi-Lagrangian investigation into dimethyl sulfide oxidation in maritime air using a combination of measurements and model, J. Geophys. Res., 105, 26379-26392, 2000.

Jenkin, M. E., Saunders, S. M., and Pilling, M. J.: The tropospheric degradation of volatile organic compounds: a protocol for mechanism development, Atmos. Environ., 31, 81-104, 1997.

Johnson, J. E., Gammon, R. H., Larsen, J., Bates, T. S., Oltmans, S. J., and Farmer, J. C.: Ozone in the marine boundary layer over the Pacific and Indian Oceans: Latitudinal gradients and diurnal cycles, J. Geophys. Res., 95, 11 847-11 856, 1990.

Junkermann, W. and Stockwell, W. R.: On the budget of photooxidants in the marine boundary layer of the tropical South Atlantic, J. Geophys. Res., 104, 8039-8046, 1999.

Kaiser, E. W. and Wallington, T. J.: FTIR product study of the $\mathrm{Cl}$-initiated oxidation of $\mathrm{CH}_{3} \mathrm{Cl}$ : Evidence for $\mathrm{HCl}$ elimination from the chloromethoxy radical, J. Phys. Chem., 98, 5679-5685, 1994.

Knipping, E. M., Lakin, M. J., Foster, K. L., Jungwirth, P., Tobias, D. J., Gerber, R. B., Dabdub, D., and Finlayson-Pitts, B. J.: Experiments and simulations of ion-enhanced interfacial chemistry on aqueous $\mathrm{NaCl}$ aerosols, Science, 288, 301-306, 2000.

Kondo, Y., Koike, M., Kawakami, S., Singh, H. B., Nakajima, H., Gregory, G. L., Blake, D. R., Sachse, G. W., Merrill, J. T., and Newell, R. E.: Profiles and partitioning of reactive nitrogen over the Pacific Ocean in winter and early spring, J. Geophys. Res., 102, 28 405-28 424, 1997.

Koppmann, R., Bauer, R., Johnen, F. J., Plass, C., and Rudolph, J.: The distribution of light nonmethane hydrocarbons over the midAtlantic: Results of the Polarstern cruise ANT VII/1, J. Atmos. Chem., 15, 215-234, 1992.

Kritz, M. A. and Rancher, J.: Circulation of $\mathrm{Na}, \mathrm{Cl}$, and $\mathrm{Br}$ in the tropical marine atmosphere, J. Geophys. Res., 85, 1633-1639, 1980.

Kwok, E. S. C. and Atkinson, R.: Estimation of hydroxyl radical reaction rate constants for gas-phase organic compounds using a structure-reactivity relationship: An update, Atmos. Environ., 29, 1685-1695, 1995.

Kylling, A.: Phodis, a program for calculation of photodissociation rates in the Earth's atmosphere, available by anonymous ftp to ftp.nilu.no, cd pub/phodis, 1995

Kylling, A., Stamnes, K., and Tsay, S.-C.: A reliable and efficient two-stream algorithm for spherical radiative transfer: Documentation of accuracy in realistic layered media, J. Atmos. Chem., 21, 115-150, 1995.
Lamontagne, R. A., Swinnerton, J. W., and Linnenbom, V. J.: $\mathrm{C}_{1-}$ $\mathrm{C}_{4}$ hydrocarbons in the North and South Pacific, Tellus, 26, $71-$ 77, 1974.

Leser, H., Hönninger, G., and Platt, U.: MAX-DOAS measurements of $\mathrm{BrO}$ and $\mathrm{NO}_{2}$ in the marine boundary layer, Geophys. Res. Lett., 30(10), 1537, doi:10.1029/2002GL015811, 2003.

Levy, H., II, Mahlman, J. D., Moxim, W. J., and Liu, S. C.: Tropospheric ozone: The role of transport, J. Geophys. Res., 90, 3753-3772, 1985.

Lewis, A. C., McQuaid, J. B., Carslaw, N., and Pilling, M. J.: Diurnal cycles of short-lived tropospheric alkenes at a north Atlantic coastal site, Atmos. Environ., 33, 2417-2422, 1999.

Lewis, A. C., Carpenter, L. J., and Pilling, M. J.: Nonmethane hydrocarbons in Southern Ocean boundary layer air, J. Geophys. Res., 106, 4987-4994, 2001.

Libuda, H. G.: Spektroskopische und kinetische Untersuchungen an halogenierten Carbonylverbindungen von atmosphärischem Interesse, PhD Thesis, University of Wuppertal, Germany, 1992.

Libuda, H. G., Zabel, F., Fink, E. H., and Becker, K. H.: Formyl chloride: UV absorption cross sections and rate constants for the reactions with $\mathrm{Cl}$ and $\mathrm{OH}$, J. Phys. Chem., 94, 5860-5865, 1990.

Lind, J A., Lazrus, A. L., and Kok, G. L.: Aqueous phase oxidation of sulfur(IV) by hydrogen peroxide, methylhydroperoxide, and peroxyacetic acid, J. Geophys. Res., 92, 4171-4177, 1987.

McConnell, J. C., Henderson, G. S., Barrie, L., Bottenheim, J., Niki, H., Langford, C. H., and Templeton, E. M. J.: Photochemical bromine production implicated in Arctic boundary-layer ozone depletion, Nature, 355, 150-152, 1992.

Mozurkewich, M.: Mechanisms for the release of halogens from sea-salt particles by free radical reactions, J. Geophys. Res., 100, 14 199-14 207, 1995.

Nagao, I., Matsumoto, K., and Tanaka, H.: Sunrise ozone destruction found in the sub-tropical marine boundary layer, Geophys. Res. Lett., 26, 3377-3380, 1999.

Nakano, Y., Goto, M., Hashimoto, S., Kawasaki, M., and Wallington, T.: Cavity ring-down spectroscopic study of the reactions of $\mathrm{Br}$ atoms and $\mathrm{BrO}$ radicals with dimethyl sulfide, J. Phys. Chem. A, 105, 11 045-11 050, 2001.

Oltmans, S. J. and Levy, H., II: Surface ozone measurements from a global network, Atmos. Environ., 28, 9-24, 1994.

Orlando, J. J., Tyndall, G. S., and Wallington, T. J.: Atmospheric oxidation of $\mathrm{CH}_{3} \mathrm{Br}$ : Chemistry of the $\mathrm{CH}_{2} \mathrm{BrO}$ radical, J. Phys Chem., 100, 7026-7033, 1996.

Orlando, J. J., Tyndall, G. S., Bilde, M., Ferronato, C., Wallington, T. J., Vereecken, L., and Peeters, J.: Laboratory and theoretical study of the oxy radicals in the $\mathrm{OH}$ - and $\mathrm{Cl}$-initiated oxidation of ethene, J. Phys. Chem. A, 102, 8116-8123, 1998.

Pandis, S. N. and Seinfeld, J. H.: Sensitivity analysis of a chemical mechanism for aqueous-phase atmospheric chemistry, J. Geophys. Res., 94, 1105-1126, 1989.

Penkett, S. A., Jones, B. M. R., Rycroft, M. J., and Simmons, D. A.: An interhemispheric comparison of the concentrations of bromine compounds in the atmosphere, Nature, 318, 550-553, 1985.

Plass, C., Koppmann, R., and Rudolph, J.: Light hydrocarbons in the surface water of the Mid-Atlantic, J. Atmos. Chem., 15, 235251, 1992.

Plass-Dülmer, C., Khedim, A., Koppmann, R., Johnen, F. J., Rudolph, J., and Kuosa, H.: Emissions of light non-methane hy- 
drocarbons from the Atlantic into the atmosphere, Global Biogeochem. Cycles, 7, 211-228, 1993.

Porter, J. N. and Clarke, A. D.: Aerosol size distribution models based on in situ measurements, J. Geophys. Res., 102, 60356045, 1997.

Pszenny, A. A. P., Prinn, R. G., Kleiman, G., Shi, X., and Bates, T. S.: Nonmethane hydrocarbons in surface waters, their sea-air fluxes and impact on $\mathrm{OH}$ in the marine boundary layer during the First Aerosol Characterization Experiment (ACE 1), J. Geophys. Res., 104, 21 785-21 801, 1999.

Quinn, P. K., Bates, T. S., Johnson, J. E., Covert, D. S., and Charlson, R. J.: Interactions between the sulfur and reduced nitrogen cycles over the central Pacific Ocean, J. Geophys. Res., 95, 16405-16416, 1990.

Rahn, K. A., Borys, R. D., and Duce, R. A.: Tropospheric halogen gases: Inorganic and organic components, Science, 192, 549550, 1976

Ramacher, B., Orlando, J. J., and Tyndall G. S.: Temperaturedependent rate coefficient measurements for the reaction of bromine atoms with a series of aldehydes, Int. J. Chem. Kinet., 32, 460-465, 2000.

Ramacher, B., Orlando, J. J., and Tyndall G. S.: Temperaturedependent rate coefficient measurements for the reaction of bromine atoms with trichloroethene, ethene, acetylene, and tetrachloroethene in air, Int. J. Chem. Kinet., 33, 198-211, 2001.

Rancher, J. and Kritz, M. A.: Diurnal fluctuations of $\mathrm{Br}$ and I in the tropical marine atmosphere, J. Geophys. Res., 85, 5581-5587, 1980.

Ratte, M., Plass-Dülmer, C., Koppmann, R., Rudolph, J., and Denga, J.: Production mechanism of C2-C4 hydrocarbons in seawater: Field measurements and experiments, Global Biogeochem. Cycles, 7, 369-378, 1993.

Ratte, M., Bujok, O., Spitzy, A., and R., Rudolph, J.: Photochemical alkene formation in seawater from dissolved organic carbon: Results from laboratory experiments, J. Geophys. Res., 103, 5707-5717, 1998.

Régimbal, J.-M. and Mozurkewich, M.: Kinetics of peroxynitric acid reactions with halides at low $\mathrm{pH}$, J. Phys. Chem. A, 104, 6580-6589, 2000.

Rudolph, J., Koppmann, R., and Plass-Dülmer, Ch.: The budgets of ethane and tetrachloroethene: Is there evidence for an impact of reactions with chlorine atoms in the troposphere?, Atmos. Environ., 30, 1887-1894, 1996.

Rudolph, J., Ramacher, B., Plass-Dülmer, C., Müller, K.-P., and Koppmann, R.: The indirect determination of chlorine atom concentration in the troposphere from changes in the patterns of nonmethane hydrocarbons, Tellus, 49B, 592-601, 1997.

Ruggaber, A., Dlugi, R., Bott, A., Forkel, R., Herrmann, H., and Jacobi, H.-W.: Modelling of radiation quantities and photolysis frequencies in the aqueous phase in the troposphere, Atmos. Environ., 31, 3137-3150, 1997.

Russell, J. J., Seetula, J. A., and Gutman, D.: Kinetics and thermochemistry of methyl, ethyl, and isopropyl. Study of the equilibrium $\mathrm{R}+\mathrm{HBr} \rightleftharpoons \mathrm{R}-\mathrm{H}+\mathrm{Br}$, J. Am. Chem. Soc., 110, 3092-3099, 1988.

Saito, T., Yokouchi, Y., and Kawamura, K.: Distributions of $\mathrm{C}_{2}-\mathrm{C}_{6}$ hydrocarbons over the western North Pacific and eastern Indian Ocean, Atmos. Environ., 34, 4373-4381, 2000.
Sander, R. and Crutzen, P. J.: Model study indicating halogen activation and ozone destruction in polluted air masses transported to the sea, J. Geophys. Res., 101, 9121-9138, 1996.

Sander, R., Vogt, R., Harris, G. W., and Crutzen, P. J.: Modeling the chemistry of ozone, halogen compounds, and hydrocarbons in the arctic troposphere during spring, Tellus, 49B, 522-532, 1997.

Sander, R., Rudich, Y., von Glasow, R., and Crutzen, P. J.: The role of $\mathrm{BrNO}_{3}$ in marine tropospheric chemistry: A model study, Geophys. Res. Lett., 26, 2857-2860, 1999.

Sander, R., Keene, W. C., Pszenny, A. A. P., Arimoto, R., Ayers, G. P., Baboukas, E., Cainey, J. M., Crutzen, P. J., Duce, R. A., Hönninger, G., Huebert, B. J., Maenhaut, W., Mihalopoulos, N., Turekian, V. C., and Van Dingenen, R.: Inorganic bromine in the marine boundary layer: a critical review, Atmos. Chem. Phys., 3, 1301-1336, 2003,

SRef-ID: 1680-7324/acp/2003-3-1301.

Saunders, S. M., Jenkin, M. E., Derwent, R. G., and Pilling, M. J.: Protocol for the development of the Master Chemical Mechanism, MCM v3 (Part A): tropospheric degradation of nonaromatic volatile organic compounds, Atmos. Chem. Phys., 3, 161-180, 2003,

SRef-ID: 1680-7324/acp/2003-3-161.

Sehested, J., Nielsen, O. J., and Wallington, T. J.: Absolute rate constants for the reaction of NO with a series of peroxy radicals in the gas phase at $295 \mathrm{~K}$, Chem. Phys. Lett., 213, 457-464, 1993.

Shepson, P. B., Sirju, A.-P., Hopper, J. F., Barrie, L. A., Young, V., Niki, H., and Dryfhout, H.: Sources of sinks of carbonyl compounds in the Arctic Ocean boundary layer: Polar Ice Floe Experiment, J. Geophys. Res., 101, 21 081-21 089, 1996.

Singh, H. B., Gregory, G. L., Anderson, B., Browell, E., Sachse, G. W., Davis, D. D., Crawford, J., Bradshaw, J. D., Talbot, R., Blake, D. R., Thornton, D., Newell, R., and Merrill, J.: Low ozone in the marine boundary layer of the tropical Pacific Ocean: Photochemical loss, chlorine atoms, and entrainment, J. Geophys. Res., 101, 1907-1917, 1996a.

Singh, H. B., Thakur, A. N., Chen, Y. E., and Kanakidou, M.: Tetrachloroethylene as an indicator of low $\mathrm{Cl}$ atom concentrations in the troposphere, Geophys. Res. Lett., 23, 1529-1532, 1996b.

Singh, H., Chen, Y., Staudt, A., Jacob, D., Blake, D., Heikes, B., and Snow, J.: Evidence from the Pacific troposphere for large global sources of oxygenated organic compounds, Nature, 410, 1078-1081, 2001.

Sumner, A. L. and Shepson, P. B.: Snowpack production of formaldehyde and its effect on the Arctic troposphere, Nature, 398, 230-233, 1999.

Tang, T. and McConnell, J. C.: Autocatalytic release of bromine from Arctic snow pack during polar sunrise, Geophys. Res. Lett., 23, 2633-2636, 1996.

Thompson, A. M., Johnson, J. E., Torres, A. L., Bates, T. S., Kelly, K. C., Atlas, E., Greenberg, J. P., Donahue, N. M., Yvon, S. A., Saltzman, E. S., Heikes, B. G., Mosher, B. W., Shashkov, A. A., and Yegorov, V. I.: Ozone observations and a model of marine boundary layer photochemistry during SAGA 3, J. Geophys. Res., 98, 16 955-16968, 1993.

Toyota, K., Takahashi, M., and Akimoto, H.: Modeling multiphase halogen chemistry in the marine boundary layer with size-segregated aerosol module: Implications for quasi-sizedependent approach, Geophys. Res. Lett., 28, 2899-2902, 2001. 
Tyndall, G. S., Wallington, T. J., Hurley, M. D., and Schneider, W. F.: Rate coefficient for the reaction of $\mathrm{CH}_{2} \mathrm{OH}$ radicals with $\mathrm{Cl}_{2}$ and infrared spectra of chloromethanol and dichloromethanol, J. Phys. Chem., 97, 1576-1582, 1993.

Tyndall, G. S., Orlando, J. J., Wallington, T. J., Dill, M., and Kaiser, E. W: Kinetics and mechanisms of the reactions of chlorine atoms with ethane, propane, and n-butane, Int. J. Chem. Kinet., 29, 43-55, 1997.

Villenave, E. and Lesclaux, R.: The UV absorption spectra of $\mathrm{CH}_{2} \mathrm{Br}$ and $\mathrm{CH}_{2} \mathrm{BrO}_{2}$ and the reaction kinetics of $\mathrm{CH}_{2} \mathrm{BrO}_{2}$ with itself and with $\mathrm{HO}_{2}$ at $298 \mathrm{~K}$, Chem. Phys. Lett., 236, 376384, 1995.

Vogt, R., Crutzen, P. J., and Sander, R.: A mechanism for halogen release from sea-salt aerosol in the remote marine boundary layer, Nature, 383, 327-330, 1996.

Vogt, R., Sander, R., von Glasow, R., and Crutzen, P. J.: Iodine chemistry and its role in halogen activation and ozone loss in the marine boundary layer: A model study, J. Atmos. Chem., 32, 375-395, 1999.

von Glasow, R., Sander, R., Bott, A., and Crutzen, P. J.: Modeling halogen chemistry in the marine boundary layer, 1. Could-free MBL, J. Geophys. Res., 107(D17), 4341, doi:10.1029/2001JD000942, 2002a.

von Glasow, R., Sander, R., Bott, A., and Crutzen, P. J.: Modeling halogen chemistry in the marine boundary layer, 2. Interactions with sulfur and the cloud-covered MBL, J. Geophys. Res., 107(D17), 4323, doi:10.1029/2001JD000943, 2002b.

von Glasow, R. and Crutzen, P. J.: Model study of multiphase DMS oxidation with a focus on halogens, Atmos. Chem. Phys., 4, 589608, 2004,

\section{SRef-ID: 1680-7324/acp/2004-4-589.}

Wagner, V., von Glasow, R., Fischer, H., and Crutzen, P. J.: Are $\mathrm{CH}_{2} \mathrm{O}$ measurements in the marine boundary layer suitable for testing the current understanding of $\mathrm{CH}_{4}$ photooxidation?: A model study, J. Geophys. Res., 107(D3), doi:10.1029/2001JD000722, 2002.

Wallington, T. J., Skewes, L. M., Siegl, W. O., and Japar, S. M.: A relative rate study of the reaction of bromine atoms with a variety of organic compounds at 295 K, Int. J. Chem. Kinet., 21, 10691076, 1989.

Wallington, T. J., Hurley, M. D., and Schneider, W. F.: Atmospheric chemistry of $\mathrm{CH}_{3} \mathrm{Cl}$ : mechanistic study of the reaction of $\mathrm{CH}_{2} \mathrm{ClO}_{2}$ radicals with $\mathrm{HO}_{2}$, Chem. Phys. Lett., 251, 164173, 1996.
Weller, R., Lorenzen-Schmidt, H., and Schrems, O.: FTIR studies on the photooxidation mechanisms of $\mathrm{CH}_{3} \mathrm{Cl}, \mathrm{CH}_{3} \mathrm{Br}, \mathrm{CHBr}_{3}$ and $\mathrm{CF}_{3} \mathrm{Br}$, Ber. Bunsenges. Phys. Chem., 96, 409-413, 1992.

Wingenter, O. W., Kubo, M. K., Blake, N. J., Smith, T. W., Jr., Blake, D. R., and Rowland, F. S.: Hydrocarbon and halocarbon measurements as photochemical and dynamical indicators of atmospheric hydroxyl, atomic chlorine, and vertical mixing obtained during Lagrangian flights, J. Geophys. Res., 101, 43314340, 1996.

Wingenter, O. W., Blake, D. R., Blake, N. J., Sive, B. C., Rowland, F. S., Atlas, E., and Flocke, F.: Tropospheric hydroxyl and atomic chlorine concentrations, and mixing timescales determined from hydrocarbon and halocarbon measurements made over the Southern Ocean, J. Geophys. Res., 104, 21 819-21 828, 1999.

Wisthaler, A., Hansel, A., Dickerson, R. R., and Crutzen, P. J.: Organic trace gas measurements by PTR-MS during INDOEX 1999, J. Geophys. Res., 107(D19), 8024, doi:10.1029/2001JD000576, 2002.

Yarwood, G., Peng, N., and Niki, H.: FTIR study of the mechanism of the $\mathrm{Cl}$ and $\mathrm{Br}$ atom initiated oxidation of acetylene, J. Phys. Chem., 95, 7330-7337, 1991.

Yarwood, G., Peng, N., and Niki, H.: FTIR spectroscopic study of the $\mathrm{Cl}$ - and $\mathrm{Br}$-atom initiated oxidation of ethene, Int. J. Chem. Kinet., 24, 369-383, 1992.

Yokouchi, Y., Mukai, H., Yamamoto, H., Otsuki, A., Saitoh, C., and Nojiri, Y.: Distribution of methyl iodide, ethyl iodide, bromoform, and dibromomethane over the ocean (east and southeast Asian seas and the western Pacific), J. Geophys. Res., 102, 88058809, 1997.

Yokouchi, Y., Li, H.-J., Machida, T., Aoki, S., and Akimoto, H.: Isoprene in the marine boundary layer (Southeast Asian Sea, eastern Indian Ocean, and Southern Ocean): Comparison with dimethyl sulfide and bromoform, J. Geophys. Res., 104, 80678076, 1999.

Zafiriou, O. C. and McFarland, M.: Nitric oxide from nitrite photolysis in the central equatorial Pacific, J. Geophys. Res., 86, 31733182, 1981.

Zhou, X. and Mopper, K.: Photochemical production of lowmolecular-weight carbonyl compounds in seawater and surface microlayer and their air-sea exchange, Mar. Chem., 56, 201-213, 1997. 